SCHOOL OF CIVIL ENGINEERING

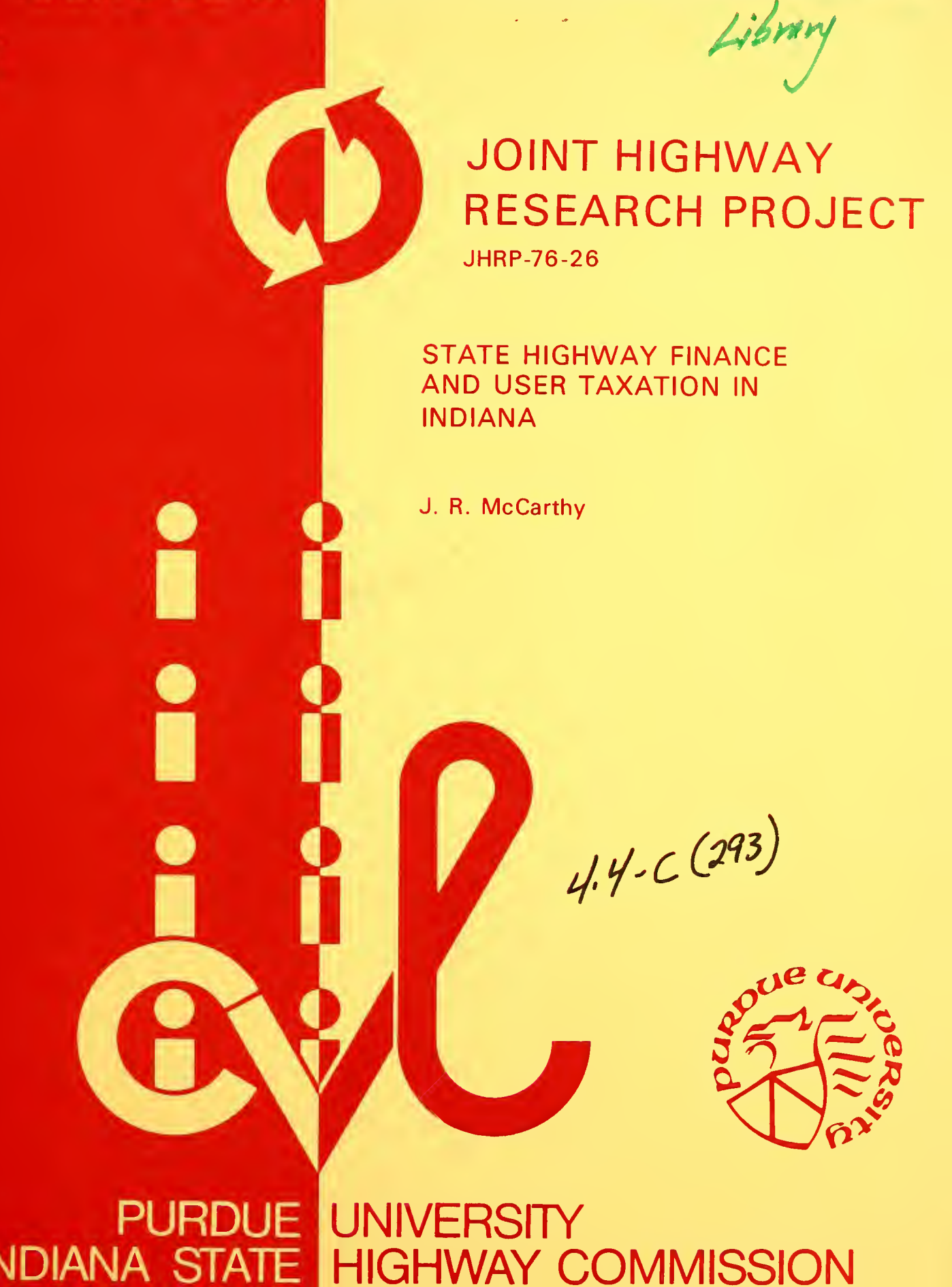





\section{Final Report}

STATE HIGHWAY FINANCE AND USER

TAXATION IN INDIANA

T0: J.F. MCLaughlin, Director

Joint Highway Research Project

FROM: H. L. Michael, Associate Director

Joint Highway Research Project
October 5, 1976

Project: $\quad C-36-73 E$

File: $\quad 3-4-5$

The attached Final Report titled "State Highway Finance and User Taxation in Indiana" is the result of efforts initiated in early 1976 to be of possible assistance to the State's Transportation Advisory Commission. Because of the short time available for the Study, we initiated efforts in the highway finance area in the event we were asked to do a study in the area of highway needs and finance. The task relative to needs was assigned to others and that of finance to the staff of the commission. As we had available considerable data from other states and because of our continuing interest and study in this area, the material has been prepared in the form of the attached report as information.

The Report presents a review of highway cost allocation and taxation methodology, a summary of highway finance in Indiana, the results of a survey of highway finance in other states, and projections of highway revenue in Indiana under current policies. Several examples of possible means of increasing these revenues are discussed and evaluated.

The Report was authored by Mr. J. R. McCarthy, Graduate Instructor in Research of our staff under the direction of Professor K. C. Sinha, Research Engineer. The Report is presented to the Board for information and for approval of release as information.

HLM :mS

Respectfully submitted,
CC: W. L. Dolch
R. L. Eskew
M. L. Hayes
C. F. Scholer
G. D. Gibson
K. R. Hoover
M. B. Scott
W. H. Goetz
G. A. Leonards
K. C. Sinha
M. J. Gutzwiller
C. W. Lovell
L. E. Wood
G. K. Hallock
R. D. Miles
P. L. Owens
E. J. Yoder
D. E. Hancher
G. T. Satterly
S. R. Yoder 
Digitized by the Internet Archive in 2011 with funding from

LYRASIS members and Sloan Foundation; Indiana Department of Transportation 


\title{
Final Report \\ STATE HIGHWAY FINANCE AND USER \\ TAXATION IN INDIANA
}

\author{
by \\ John R. McCarthy \\ Graduate Instructor in Research
}

Joint Highway Research Project

Project No.: C-36-73E

File No.: 3-4-5

Prepared as Part of an Investigation
Conducted by
Joint Highway Research Project
Engineering Experiment Station
Purdue University
in cooperation with the
Indiana State Highway Commission

Purdue University

West Lafayette, Indiana

october 5, 1976 
AC KNOWLEDGMENTS

The author wishes to recognize the support and help given by his major professor, Kumares C. Sinha. His understanding and suggestions helped to avoid many pitfalls that would have otherwise been encountered. Recognition is also given to Professor Harold L. Michael, whose direction prompted this project and whose supply of information was invaluable. The author also wishes to thank Jean E. Hittle for his valuable contribution to this project.

Highest recognition is given to the author's wife, Peggy, for her typing and loving support of this project. Many thanks are also given to fellow graduate students who provided encouragement for this research.

The author is grateful to the Joint Highway Research Project for the financial assistance received in the conduct of this research

And most of a11, thanks to the Lord who provides the true wisdom for al1 men. 
TABLE OF CONTENTS

Page

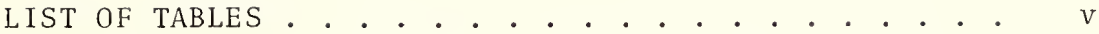

LIST OF FIGURES . . . . . . . . . . . . . . . . . viii

ABSTRACT . . . . . . . . . . . . . . . . . . . ix

CHAPTER I - INTRODUCTION . . . . . . . . . . . . 1

Purpose and Scope . . . . . . . . . . . . . 2

The Highway Today . . . . . . . . . . . . . . . 3

Decreased Fuel Consumption . . . . . . . . . 8

Social and Environmental Issues . . . . . . . 10

Indiana Highway Needs . . . . . . . . . . . 11

CHAPTER II - METHODS OF HIGHWAY COST ALLOCATION AND

TAXATION . . . . . . . . . . . . . . . . 13

User and Nonuser Cost Responsibility . . . . . 13

Cost Allocation Between Users and Nonusers . . . 14

Highway User Cost Allocation . . . . . . . . 17

Review of Highway Taxation and Financing . . . . 22

Brief History of Indiana Highway Taxation . . . . 24

CHAPTER III - FINANCING OF STATE HIGHWAYS IN INDIANA - 28

Motor Vehicle Highway Account . . . . . . . . 29

Distribution of the Motor Vehicle Highway Account 32

Special Accounts . . . . . . . . . . . . . 32

Activity in the Motor Vehicle Highway Account . 34

CHAPTER IV - A SURVEY OF STATE HIGHWAY FINANCING IN THE

UNITED STATES . . . . . . . . . . . . . 38

The Questionnaire . . . . . . . . . . . . 38

Summary of Responses . . . . . . . . . . 39

Commentary . . . . . . . . . . . . . . 54

CHAPTER V - AD VALOREM TAXATION . . . . . . . . 66

Specific Proposals by Two States . . . . . . . 71

The Washington Proposal . . . . . . . 71

The Utah Proposal . . . . . . . . . 72 
TABLE OF CONTENTS, cont.

Page

CHAPTER Vi - pROJECTED INDIANA HighWAY REVENUES . • . 75

Indiana Highway Needs . . . . . . . . . 75

State Highway Revenue Forecasting Methodology . 76

Population . . . . . . . . . . . 76

Vehicles Per Capita . . . . . . . . . 81

Vehicle Miles of Travel . . . . . . . . . . 83

Estimated State Highway User Revenue . . . . . 85

Total Highway User Revenues . . . . . . . . . 96

Alternatives for Increasing User Revenues . . . 98

Example A. . . . . . . . . . . . . . . 99

Example B. . . . . . . . . . . . . . 101

Example C. . . . . . . . . . . . . 102

CHAPTER VII - SUMMARY AND EVALUATION . . . . . . 104

Example A Summary............... 106

Example B Summary. . . . . . . . . . . . 109

Examp1e C Summary. . . . . . . . . . . 114

CHAPTER VIII CONCLUSIONS . . . . . . . . . . . 117

NOTES . . . . . . . . . . . . . . 119

LIST OF REFERENCES ............... . . 123

APPENDICES

Appendix A . . . . . . . . . . 128

Appendix B . . . : . : . : . : . 130

Appendix C . . . . . . . . . 137 


\section{LIST OF TABLES}

Table

Page

1 Maintenance Material Cost Increases-Fort Wayne . . 5

2 Comparison of Incremental, Gross Ton-Mile, Cost Function, and Differential-Benefits Methods . . . 21

3 Jurisdiction of Indiana Highway Mileage . . . . 28

4 Motor Vehicle Highway Account Operating Expenses, $1971-1975$

5 Fiscal Activity in the Motor Vehicle Account . . 36

6 Motor Vehicle Highway Account Disbursements, $1970-1975$. . . . . . . . . . . . . 35

7 Types of Highway Fund Support - 1976 . . . . . . 40

8 Specific State Highway Revenue Sources . . . . . . 41

9 State and Federal Road User Tax Receipts for State Administered Highways 1974 . . . . . . . . . . 42

10 Gasoline Taxation Methods . . . . . . . . . . 44

11 Legislative Changes in the Gasoline Tax . . . . . 46

12 Diesel Fuel Tax Rates . . . . . . . . . . . 48

13 Automobile Registration Criterion . . . . . . . . 51

14 Noteworthy Sources of Highway Revenue - Selected States... . . . . . . . . . . . 55

15 Fue1 Tax Rates - Indiana and U.S. . . . . . . . 56

16 Summary of State Automobile Registration Fee Schedules . . . . . . . . . . . 59

17 Summary of State Motor Truck Registration Fee Schedules . . . . . . . . . . . 60 


\section{LIST OF TABLES, cont.}

Table

18 Comparison of Indiana's State Highway-User Revenues with Other Midwest States and National Averages, 1975

19 Mileage and User Revenue Distribution for Selected States ................. 63

20 Indiana Population Projections . . . . . . 79

21 Projections of Indiana Vehicles Per Capita, 19801995 . . . . . . . . . . . . 83

22 Adjusted Per Capita Income Projections . . . . 85

23 Estimated Indiana Vehicle Registration Revenue . 88

24 Estimated Indiana Vehicle Miles of Travel 1980-199591

25 Average Miles Per Gallon Assumptions, Total Vehicle Fleet Mix 1980-1995 ............. 92

26 Example of Motor Fuel Tax Revenue Computation 19801995 . . . . . . . . . . . . 9 95

27 Example of Estimated Indiana State Highway User Revenue Computation 1980-1995......... 97

28 Indiana's State Highway-User Revenue, 1975 • . 107

29 Additional Revenues Generated by Alternative Taxation Policies ................ 108

30 Highway User Revenue Estimates-Per Gallon Assumptions ............. 110

31 Projected Motor Fuel Prices 1980-1995 ..... . 111

32 Ad Valorem Tax Conversions . . . . . . . 112

33 Highway User Revenue Estimates-Ad Valorem As sumptions 
Appendix A: Indiana's Estimated State Payments Into and Apportionments From the Federa1 Highway Trust Fund... . 


\section{LIST OF FIGURES}

Figure

Page

1 Effects of Inflation on Oregon Highway Economy . 4

2 Price Trends for Highway Construction . . . . . . 6

3 Highway Maintenance and Operation Cost Index . . 7

4 Estimated Indiana State User Revenues Under Varying Fuel Consumption Alternatives . . . . . . 9 9

5 Motor Vehicle Highway Account . . . . . . . . 30

6 Current State Gasoline Tax . . . . . . . . 45

7 Year of Last Gasoline Fuel Tax Change . . . . . . 47

8 Auto Registration, Flat Fee Selected States... . 52

9 Selected Fuel Tax Rates . . . . . . . . . 57

10 Expenditures Per Vehicle Mile of Travel for Maintenance on Roads Under State Jurisdiction . . . . 64

11 Flow Chart, State Highway User Revenue Forecast 77

12 Indiana Population Projections . . . . . . . . 80

13 Projected Vehicles Per Capita . . . . . . . . . 82

14 Estimated Indiana Vehicle Miles of Trave1 . . . . 86

15 Forecast of Total Motor Vehicle Registrations . . 89

16 Forecast of Vehicle Registration Fees . . . . . . 90

17 Average Miles Per Gallon Assumptions-Total Fleet $\operatorname{Mix} \cdot$. • . . . • • . . . . . . . .

18 Highway User Revenues Generated by Alternative Plans... . . . . . . . . . . 115 
ABSTRACT

McCarthy, John Raymond. MSCE, Purdue University, December 1976. State Highway Finance and User Taxation in Indiana. Major Professor: Kumares C. Sinha.

Social and environmental issues, rising cost of highway materials, and decreasing fuel consumption will all have considerable impact on the future financing of Indiana's highways, roads and streets. While highway revenues have not changed significantly over the past few years, highway construction and maintenance costs have more than doubled. Because of these challenges to Indiana's highways, this research was designed to examine the alternatives available for increasing highway user revenue in Indiana, as well as how other states are handling these revenue problems.

A questionnaire survey regarding current financing and taxation policies sent to the states, showed a definite need for increased highway revenues to meet escalating costs in most states. Many states indicated they are seriously studying a motor fuel tax which would, in some way, be indexed to inflation. A promising method of increasing revenues appears to be the adoption of an ad valorem tax, similar in nature to a sales tax, on motor fuel consumption. 
As a consequence of this research, three major alternative examples for increasing highway user revenue were examined. The first example included reproportioning of Indiana's registration and motor vehicle fees upward to compare with national averages. The second example involved increasing motor fuel revenues by a one-cent per gallon tax increase or adoption of a 20 percent ad valorem tax in 1 ieu of the present motor fuel taxation structure. The final example combined an ad valorem tax with a reproportionment of user fees to national averages. Under conservative assumptions, this last example generated an additional 92 million dollars for highways or over twice the additional revenues generated by any of the other examples. Using the criterion of revenue generating capabilities and compatibility with methods and procedures presently utilized for collection of fuel taxes, a proposal including an appropriate ad valorem tax appears to be most beneficial. 


\section{CHAPTER I}

\section{INTRODUCTION}

Today, American's are more dependant on automobile highway travel for the bulk of their daily needs than ever before. Automobiles, trucks and buses accounted for 98.3 percent of all person trips made in the United States in 1975 [1]. In addition, 1.3 million people are employed directly in the manufacture of vehicles, parts and equipment and another 13.4 million Americans work in motor vehicle related jobs [2]. Because the economic impact and the ubiquity of highway travel surmount any other transportation mode, financing the construction and maintenance of this comprehensive system of highways and streets is of considerable importance.

Indiana's centralized location in the United States makes it a key element in the overall national highway system. Over 36 billion miles are traveled annually in Indiana [3]. By 1995, it is estimated over 50 billion miles will be traveled by some 4.7 million motor vehicles. This indicates substantial growth for the State highway system in the next twenty years along with greater demands placed on all highway facilities. Immediate legislative 
involvement in transportation policy issues is needed on a continuing basis if Indiana highways are to receive adequate financing.

\section{Purpose and Scope}

This research is intended to provide information for highway officials and those directly involved with the financing and taxation policies of Indiana state Highways. The four major objectives sought in the course of this research were:

(1) To review the principles and historical development of taxation policies as related to highway finance with particular reference to Indiana.

(2) To examine the deficiencies of the present taxation mechanisms for highways and discuss the future consequences of such factors.

(3) To review the current highway taxation policies followed by the different states in the U.S.

(4) To generate information regarding the possible actions that can be taken to meet the future needs of Indiana State Highways.

The need for a study of state highway financing and taxation is critical. Many states have indicated their concern with the availability of adequate future revenues for highways. Financial planning and legislation providing proper funding can help to dispel these concerns. Legislators in particular must become better acquainted with the issues and problems facing today's highways. 


\section{The Highway Today}

There are some specific social issues and disturbing cost trends confronting the present highway system and those involved with their financing. Decreased fuel consumption, rising material costs for highways, and environmental concerns will all have impacts on future financing policies for highways. Unless there is financial planning for highways, concerned with these issues, the highway system will decline from its present level of service.

In recent years, the United States has experienced significant increases in the general inflation rate, as have other countries throughout the world. The material prices for highway construction and maintenance have risen more than most.

Statistics show that most transportation industries have had increases in excess of the private-sector average since 1970 [4]. In the past few years, general price indicators related to highways have soared as construction, maintenance and material costs have become increasingly important items in the overall highway budget. The Indiana State Highway Commission estimated the highway cost index in the State to increase thirty percent in 1974-75 [5]. Figure 1 is taken from a report prepared by the Highway Division of the Oregon Department of Transportation, and shows the decreasing purchasing power of the highway dollar that they have experienced. They project this declining value 


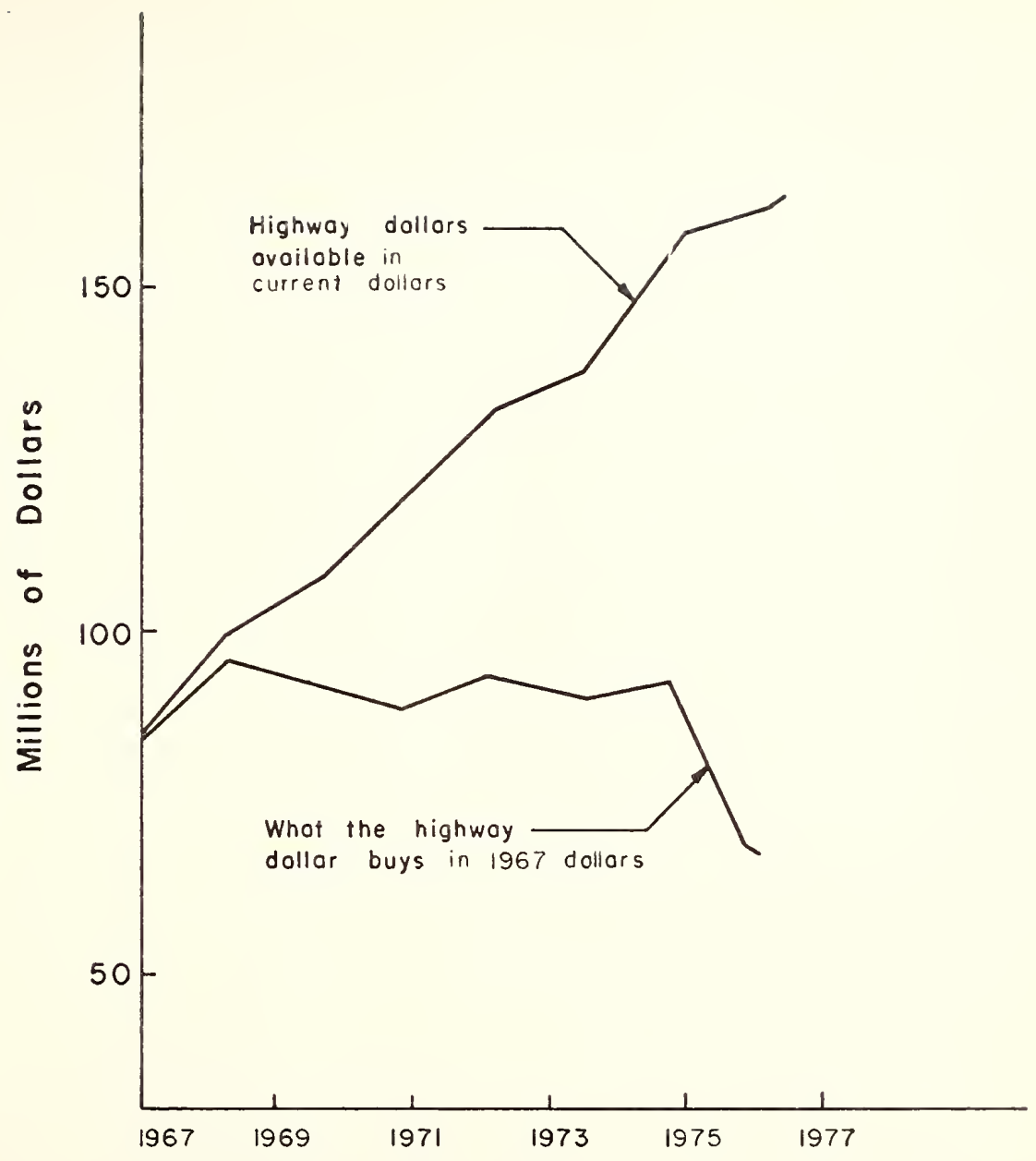

\section{FIGURE I.EFFECT OF INFLATION ON OREGON HIGHWAY ECONOMY.}

Source: Oregon Dept. of Transportation 
of the highway dollar to only grow worse in the coming years.

Price trends for highway construction based on national data are shown in Figure 2. It can be seen that the construction index rises rapidly as compared to the consumer price index. These factors also have a predominate influence on highway maintenance and operation costs. The highway maintenance and operation cost index shown in Figure 3 illustrates a 7 percent annual rise for the period 1968-1973. Again, petrolcum cutbacks and exaggerated import prices for crude oil have increased bituminous material prices. The cost of such items as asphalt cement, hot asphalt, and asphalt base oil has risen dramatically. The following Table shows typical maintenance material cost increases experienced in the operation of the Fort Wayne, Indiana Street Department [6].

\section{Table 1}

Maintenance Material Cost Increases-Fort Wayne

\begin{tabular}{l|r|r|r|r|r}
\hline \multicolumn{1}{c}{1972} & \multicolumn{1}{c}{1973} & \multicolumn{1}{c}{1974} & \multicolumn{1}{c}{1975} & \multicolumn{1}{c}{$\begin{array}{l}\text { Increase } \\
\text { Per Year }\end{array}$} \\
\hline Fuel 0il/Gal. & 0.119 & 0.175 & 0.304 & 0.277 & $32 \%$ \\
Gasoline/Gal. & 0.195 & 0.215 & 0.40 & 0.375 & $23 \%$ \\
Asphalt Cement/Ton & 30.00 & 54.00 & 62.00 & 85.00 & $45 \%$ \\
Hot Asphalt/Ton & 6.25 & 6.90 & 13.00 & 17.00 & $42 \%$ \\
Asphalt Base Oil/Ga1. & 0.105 & 0.155 & 0.265 & & $40 \%$ \\
\hline
\end{tabular}




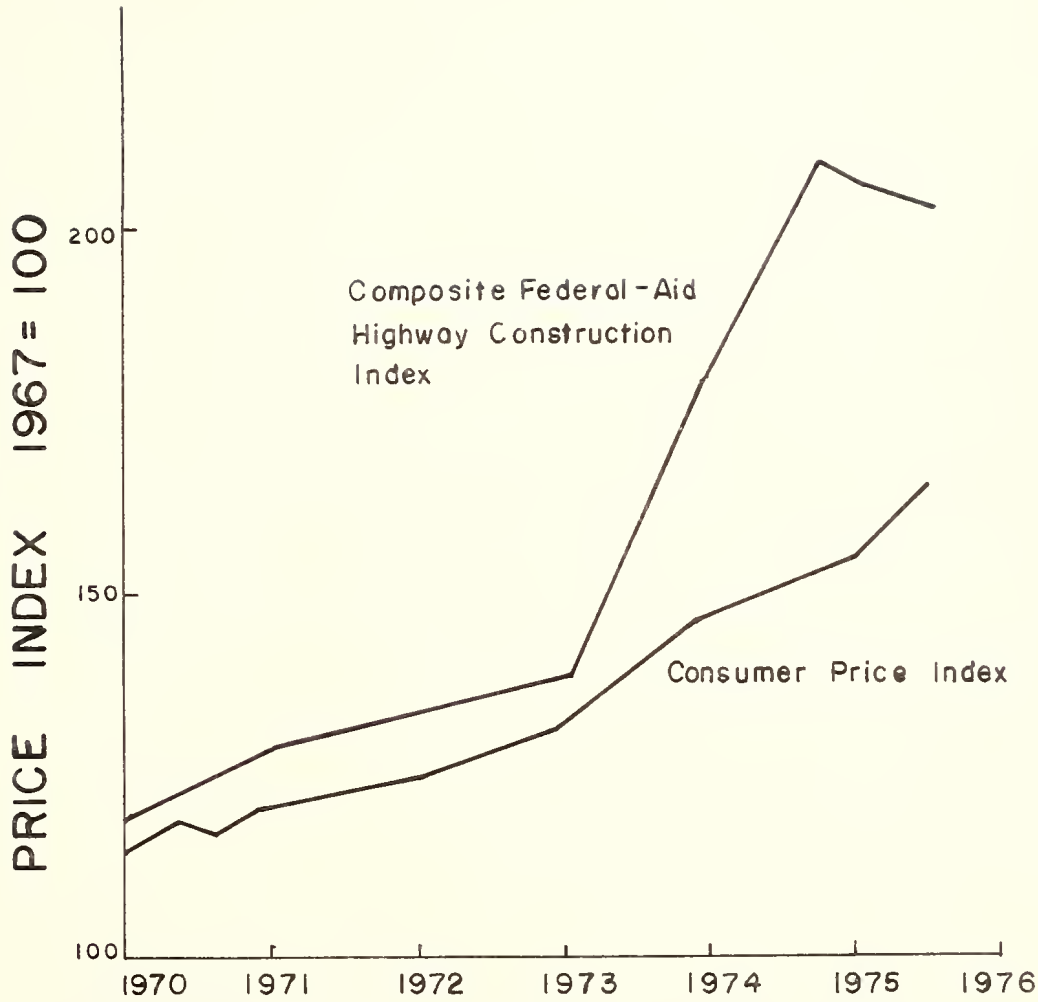

FIGURE 2. PRICE TRENDS FOR HIGHWAY CONSTRUCTION

Source: Federal Highway Administration, "Price Trends for Federal-Aid Highway Construction" 


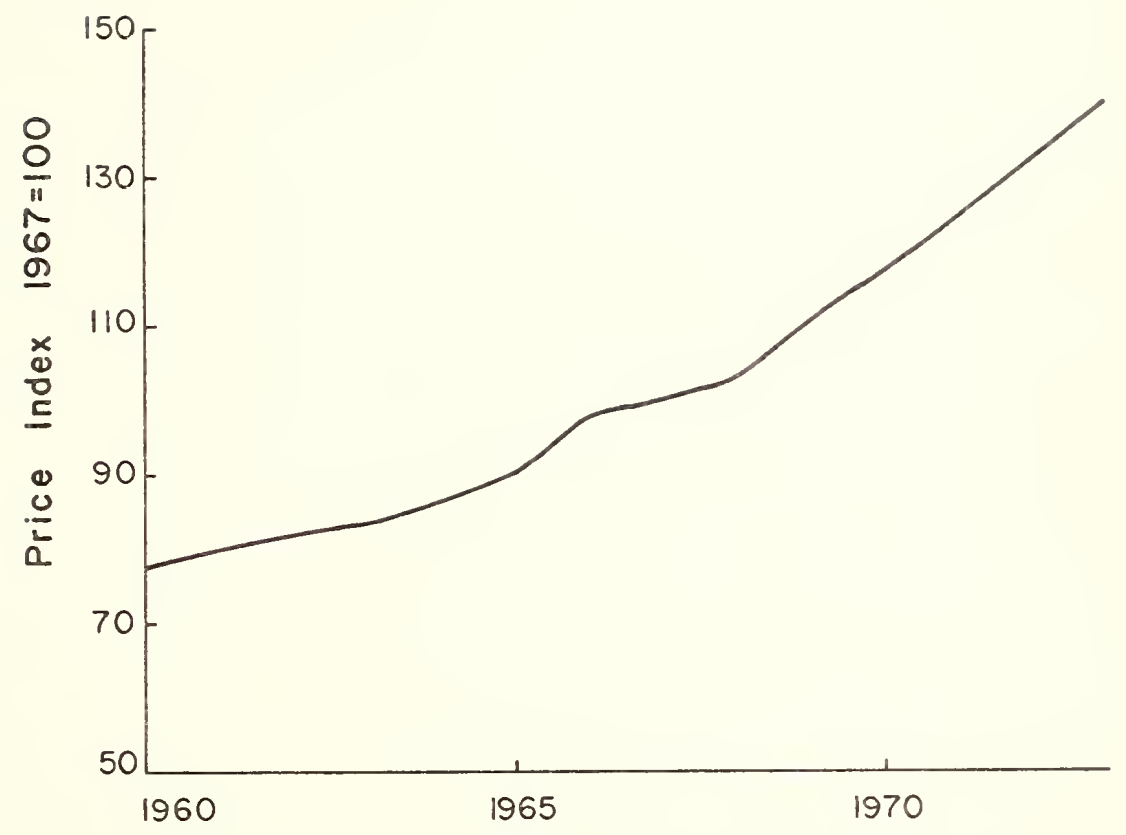

FIGURE 3. HIGHWAY MAINTENANCE AND OPERATION COST INDEX.

Source: Highway Statistics 1974 
These are typical of the increases experienced by the Indiana State Highway System.

\section{Decreased Fuel Consumption}

The imposition of $55 \mathrm{mph}$ speed limit has caused a considerable decrease in revenue for the State Highway System, because the motor fuel tax is the major source of highway revenue [7]. The recent trend in consumer preference for lighter, more efficient automobiles and the production of automobiles with smaller displacement engines and increased fuel economy to satisfy this demand is causing reduction in fuel consumption and in turn resulting in less highway revenue.

The total net amount of fuel taxed for the nation in 1973 was 110.4 billion gallons. In 1974 only 106.1 billion gallons were consumed for a decrease of 3.9 percent over the previous year. This has caused severe concern among highway officials. In Indiana, the percentage decrease in fuel consumption from 1973 to 1974 was 4.5 percent indicating a $10.4 \mathrm{million}$ dollar revenue loss from the preceding year[8]. Many states are concerned with the thought of ever reducing highway revenue due to decreasing fuel consumption and are actively seeking answers to the problem of highway finance. 


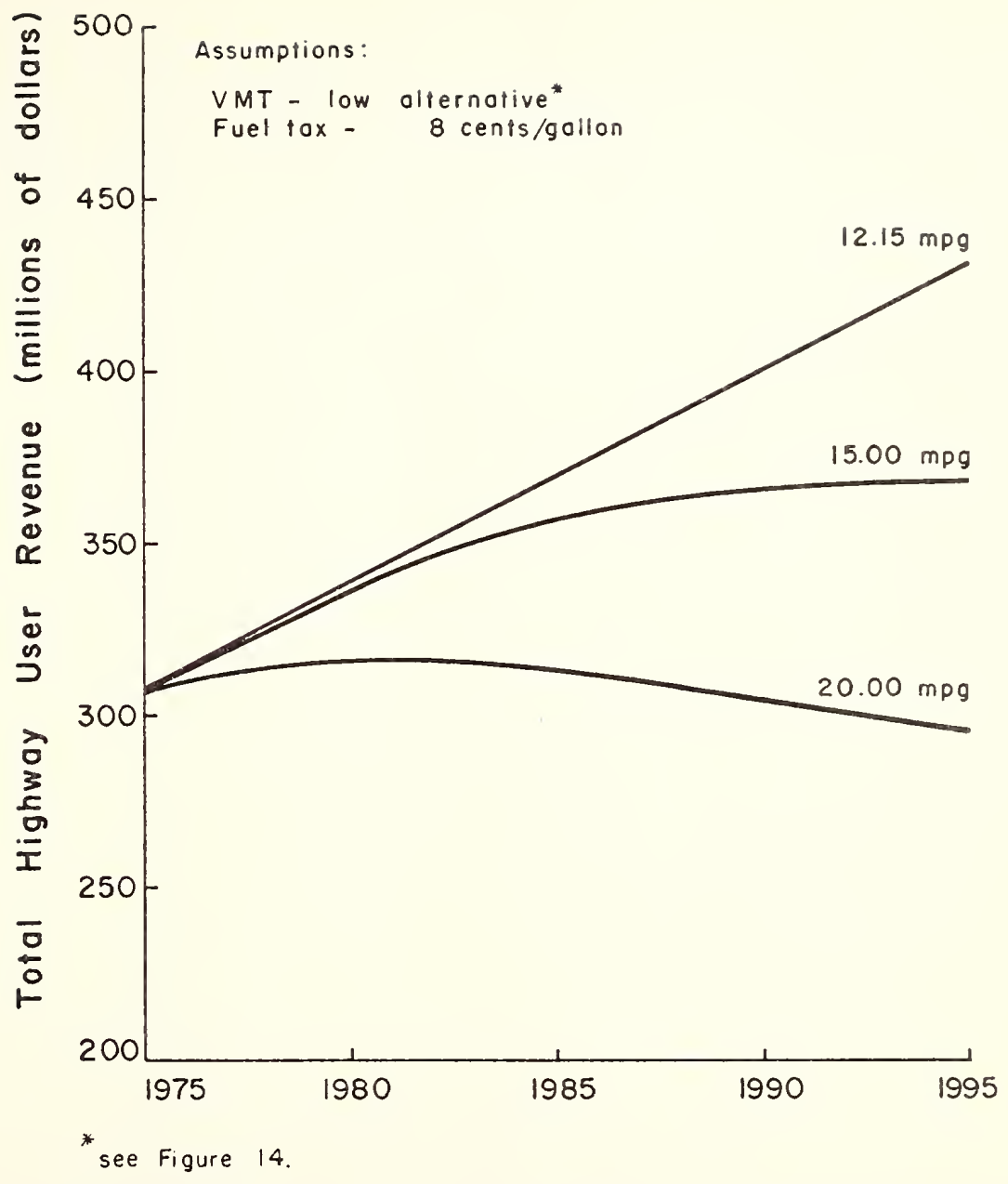

FIGURE 4.ESTIMATED INDIANA STATE HIGHWAY USER REVENUES UNDER VARYING FUEL CONSUMPTION ALTERNATIVES. 
revenues vary in relation to possible future fuel consumption rates. There is a difference of over 100 million dollars between the high and low assumptions in the year 1995. This gives evidence of the magnitude of the problem facing Indiana highways.

\section{Social and Environmental Issues}

There has been a growing concern over the negative impacts of highway facilities and services on the environment. This concern has been manifested by citizens in a number of urban areas, causing the halting of construction of new freeways or freeway segments.

Although the mileage of freeways in dispute has been smal1, this anti-freeway reaction signaled a change in attitude of some people to further environmental damage associated with urban freeways [9]. The major concerns were the displacement of homes and business, consumption of scarce urban 1 and, disruption of neighborhoods and communities, automobile accidents, noise and transportation for persons without access to automobiles [10]. Most recently, air quality concerns and energy consumption have focused the most concern. As the debate has continued, it has broadened to encompass the issue of alternatives to additional highway construction [11]. These concerns over the social, environmental and energy problems associated with highways and highway travel have increased efforts to reduce automobile travel and the negative impacts this travel produces [12]. 
It is well recognized that indiscriminate highway construction will not solve the urban transportation problens. It will take comprehensive planning of highways coordinated with complementary transit modes to provide a safe and efficient transportation network.

\section{Indiana llighway Needs}

Supplementary to these issues facing Indiana highways, there is the ever present question of highway needs. What future maintenance and construction is needed to keep this highway system at a reasonable level of service? The 1972 Indiana Transportation lecds Study estimated a need of 13 billion dollars to be disbursed for highway purposes hetween 1970 and 1990. An additional 7 billion dollars was expected for the necessary completion of the Interstate system [13].

A sreat need for additional highway funding is in the area of maintenance and improvement to the existing highway network in Indiana. Numerous miles of the Indiana Interstate System are today ten to fifteen years old and in need of repair or maintenance. Many of the design features of these highways are no longer adequate. Indiana should be replacing or reconstructing two-hundred bridges and resurfacing 1200 miles of roakway cvery year. Fecause of lack of funds, only 450 miles of roadway are currently resurfaced per year and the bridge replacement program is lagging behind schedule [14]. 
In addition, the 1972 Study estimated the State supported highways would require 7.1 billion dollars between 1970-1990. As the apparent available revenue was estimated to be only 5.0 billion a deficit of 2.1 billion dollars was projected for the twenty year period [15]. 


\section{CHAPTER I I}

METHODS OF HIGHWAY COST ALLOCATION AND TAXATION

This chapter furnishes some general information on the financing, taxation, and cost responsibility of highways. The complexities of user and nonuser cost responsibility and cost allocation are presented along with a brief history of highwy taxation and finance in Indiana.

\section{User and Nonuser Cost Responsibility}

In determining who will pay for the services provided by highways, the first allocation of cost responsibility is between users and nonusers of the highway system [16].

Determination of the nonuser benefits associated with highways is difficult to equate in monetary terms but their existence cannot be denied. The usual procedure is to determine the user share of the highway costs and assign the residual costs to the nonuser [17]. Very little has been done to evaluate accurately the nonuser portion of costs [18]. In Economic Analys is for Highways, Robley Winfrey presents an excellent summary of the two extremes between which user and nonuser cost allocation must be balanced. 
The level of service concept is highly important in arriving at a reasonable allocation of costs between users and nonusers. The local rural roads and residential streets in urban areas carry relatively light volumes of traffic and these roads and streets would be there today regardless of the motor vehicle. In fact, most of the urban places had well-defined street systems before the turn of the century. The costs of such facilities if charged to the highway user. would result in an exhorbitant cost per vehicle-mile. On the other hand the freeways, expressways, and other arterial facilities are designed to carry heavy volumes of traffic at relatively higher speed and with relatively long trip lengths. The nonuser, obviously, should be charged with only a small portion, if any, of the costs of such facilities because of their high costs per mile in relation to the abutting property. Therefore, it is necessary to find an acceptable method of allocating highway program costs between these two extremes [19].

\section{Cost Allocation Between Users and Nonusers}

Many methods of highway cost allocation have been developed over the years. Four of the more common methods will be discussed here: (1) the standard cost method, (2) the predominant use method, (3) the relative use method, (4) the earnings credit method.

\section{The Standard Cost Method}

The standard cost method is based on the premise that the cost of a "standard" highway system is representative of the user portion of highway costs. This standard cost is applied to the total ton-miles of travel for all roads and streets to determine the user share of costs. The remaining amount is then assigned as the nonuser portion. The objections to this method are: (1) the arbitrary decision made in selecting the "standard", (2) the possible use of 
a rural system as the standard thereby allocating more than an equitable amount to nonusers [20].

\section{Predominant Use Method}

In the predominant use method, highway costs are allocated in accordance with the predominant use or benefit corresponding to each type of facility. Using this criteria, expressways, freeways and other high volume facilities are considered the sole cost responsibility of the highway user. Correspondingly the low-type facilities such as residential and low volume rural streets are a nonuser cost responsibility. And the assessments of cost allocation to intermediate systems between these two extremes is on the basis of judgements as to the level of service provided by each type of facility.

This method has two major criticisms: (1) it assumes no user benefits are derived from the residential and rural streets, and (2) it assumes that nonusers derive no benefits from freeways and expressways. One other disadvantage to this method is the arbitrary judgements of allocation to intermediate type of facilities.

\section{Relative Use Method}

In the relative use method highway cost is assigned in proportion to how well each system of highway meets certain service criteria. There are three measures of service: (1) service to land access traffic, (2) service to 
community or neighborhood traffic, (3) service to through traffic.

Inputs to the relative use method are such things as origin and destination of trips, length of trips, trip purpose and routes traveled. This method involves the analysis of trip length data and assignment into one of the three catagories mentioned above. The through traffic components are considered the user share while neighborhood components are the nonuser share of the cost. A judgement must be made as to the area between these two extremes [2I]. The major drawback to use of this method is the lack of available data needed for analysis [22]. However, much work has been done with the relative use method and some feel it represents the best approach to the problem of nonuser cost allocation [23].

\section{Earnings Credit Method}

There are two major hypotheses involved with the application of the earnings credit method [24]. The first hypothesis states that the highway user is assessed the costs of construction, maintenance and operation of arterial streets providing major through traffic movement, which is consistant with the benefits received. The second hypothesis assumes that general public benefits and hence assessed costs should go for the lowest system of access roads and streets. A compromise is then drawn between these two extremes to arrive at the final user and nonuser 
cost responsibility. This compromise recognizes that each class of highway benefits both the user and nonuser.

Less judgement is required in this method than with the standard cost or relative cost methods. It approaches the solution from both sides and has yielded reasonable results. Indiana and many other states have utilized this method for allocation of cost between highway users and nonusers [25].

The methods discussed above are established on sound basic concepts; these concepts assume that the major users of the facility should provide the most support, and the nonuser should support facilities strictly for local access.

\section{Highway User Cost Allocation}

Once the user and nonuser portions of highway costs have been determined, the user share must be allocated among the different types and classes of vehicles using the highways.

There are a number of factors which make cost allocation between vehicles difficult. Highway traffic is not a homogeneous group. Motor vehicles vary in width, length, weight, number of axles, miles of highway use, fuel consumption and type of fuel used. Highway construction, maintenance and operation costs are all affected by the types of vehicles using the highway and since some of the 
costs are joint costs for all classes of vehicles, the problem of proper allocation according to some specific road-user tax base can become complex and confusing. When studying tax allocation among vehicle classes, two questions must be answered: (1) what criteria will be used to measure the tax responsibility of each vehicle class, and (2) once the criteria is found how will it be priced in relation to other vehicle classes? Some of the major methods for equitable distribution of costs to user classes are discussed below.

\section{Incrementa1 Method}

According to the incremental method the basic costs of constructing, improving and maintaining a given highway designed for passenger vehicles only, are distributed equally among all vehicle classifications. The additional cost of construction, improvement and maintenance to make the road suitable for heavier vehicles are shared by each vehicle of that class and each vehicle of greater size. Thus each vehicle pays a share of the base cost plus increments of cost up to and including the cost required by that particular vehicle [26].

The difficulty with this method is the determination of the additional costs required by each vehicle classification. 
Gross Ton-Mile Method

The gross ton-mile method of cost allocation among the various user groups is based on tha theory that each weight group should be charged according to the ton-miles of travel for each weight class. Ton-miles are assumed to be a measure of the benefits received by each weight class. Total travel is computed as an average per vehicle in each weight class and tax responsibility is distributed in proportion to the product of miles traveled and the average vehicle in each class.

Two major factors favoring this method of cost allocation are its simplicity and ease of calculation, although there are problems. This method has a tendency towards allocating a larger share of the tax responsibility to 1 arger vehicles [27].

\section{Cost Function Method}

The cost function method was developed by researchers in the motor carrier industry and is based on the factor of costs occasioned. This means that all costs are classified into one of three catagories: (1) costs associated with highway use, (2) costs related to vehicle size and weight, (3) costs which are neither size, weight or use related. 
Costs related to size and weight of vehicles are distributed on the basis of gross ton-miles of travel. Costs associated with highway use are allocated according to vehicle miles of travel and costs not in either catagory are assigned on a per vehicle basis. Winfrey feels that although the cost function method is probably more acceptable than the ton-mile method, the basic flaw of the cost function is the assignment of partial costs due to heavy vehicles, to the lighter vehicles [28]. The lightest vehicles will be paying a share of the costs caused by the heaviest pavement and highest type bridge design.

Using the cost function method it is found that trucks are assigned a lesser cost than under the gross ton-mile solution. The incremental solution assigns a higher cost to passenger vehicles. The cost function approach is seen as a medium solution falling between the other alternatives.

\section{Differential-Benefits Method}

The differential-benefits method assumes user tax payment to be proportional to benefits received by each class of vehicles. This method of tax allocation is theoretically sound, relying on the benefits received taxation theory, but the collection of the required data is a complex task. Only a few applications of the differential benefits method have been made to date [29]. Table 2 compares the four methods of cost allocation discussed for similar situations. 


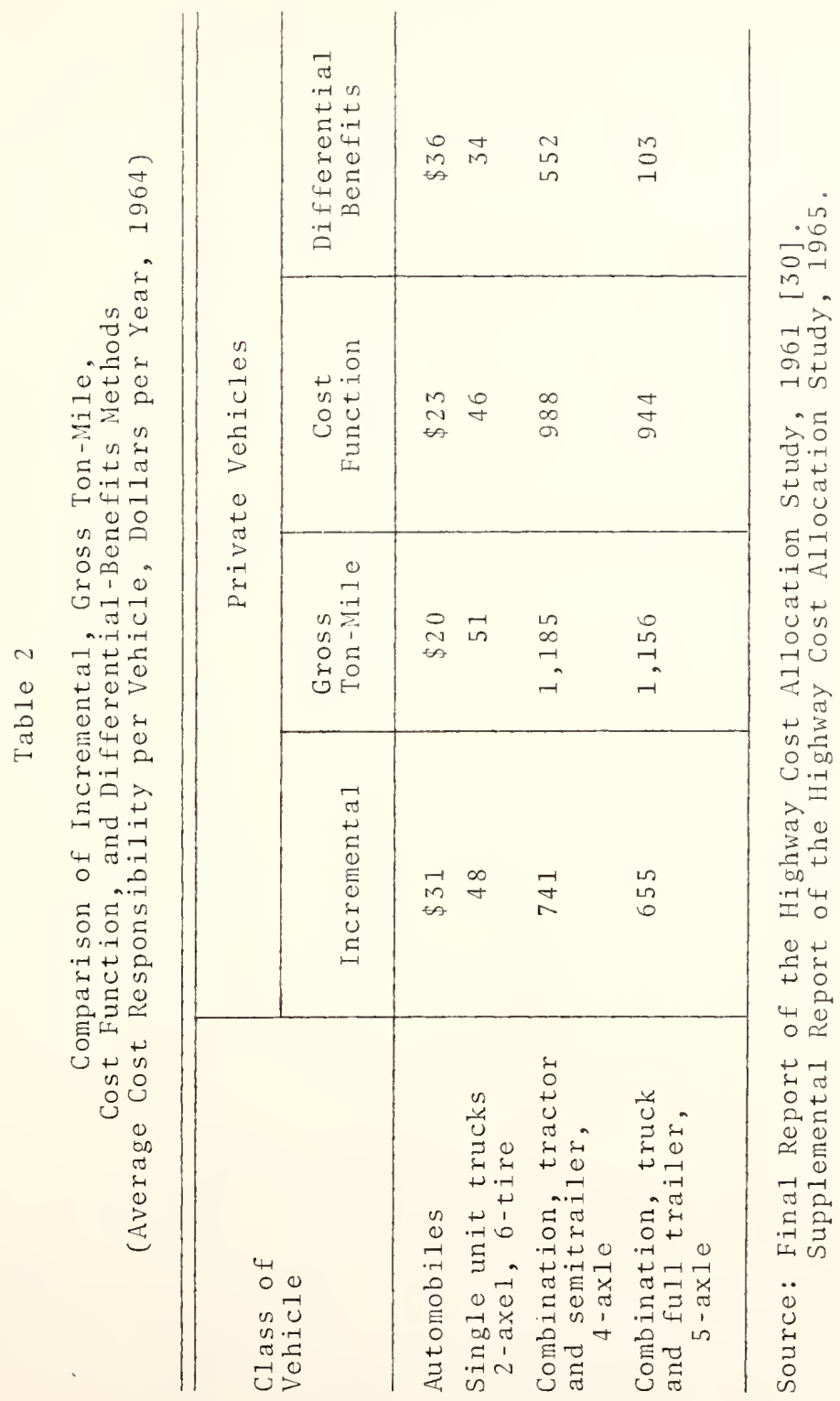


In Table 2, all four methods of cost allocation (incremental, cost function, ton-mile, differential benefits) were applied to similar costs, travel, vehicle population, and other factors. The differential-benefits method assigns the highest cost responsibility to automobiles and the lowest to the other classes of commercial vehicles. The gross ton-mile solution assigns the least cost responsibility to the automobile and the highest to heavier vehicles.

\section{Review of Highway Taxation and Financing}

From the early days of colonial America the concept of public tax support of roads has been in use. While the idea of public tax support for highways has not changed, the nature of taxation has changed. The modern concept of a user tax supported by some general fund revenue is in stark contrast to the days of "working out" one's poll tax by providing free labor to neighboring road projects. Today the main support of highways comes from road user taxes in one form or another with the general fund support of highways becoming the nonuser share of highway funds.

\section{Early Concepts of Highway Taxes}

Before the invention of the automobile, when horse and wagon were the main modes of travel, roads were still important as the means of getting from one place to another. Almost all funds available for road purposes came from 
property tax levies or from the general fund of the administering government. The automobile population grew slowly because mass production techniques had not yet been introduced. In the year 1904, rural road expenditures in the United States totaled $\$ 79.8$ million. It is interesting to note that $\$ 53.8$ million came from property or poll taxes, $\$ 19.8$ million from "labor" taxes, $\$ 3.5$ million from bond issues and $\$ 2.6$ million from state aid [31]. The $\$ 19.8$ million figure represents the dollar value placed on expended labor. At this period in history only six states provided state aid for highways.

This traditional method of highway support was soon to disappear with the increasing number of automobiles beginning to travel the roads. By 1906 it was estimated there were 108,000 motor vehicles in the United States which paid $\$ 62,500$ in vehicle registration fees. But little of this money was applied to roadwork. By 1915, motor vehicle registration had jumped to 2.4 million vehicles and registration fees increased to $\$ 18.2$ million. Most of this money was by now going for highway construction [32]. Officials were now realizing the revenue potential of the automobile for tax support of highways. This idea of highway user taxation was given a boost when in 1919 Oregon enacted the first tax on motor fuel. This tax proved so successful that by 1929 all states had placed a tax on motor fuel ranging from 2 to 6 cents per gallon [33]. This then 
marks the change from the concept of property tax support for roads to one of highway user tax revenues as the major source of highway funds.

Revenues from the combined taxes, motor fuel and registration, increased rapidly. With the predominance of such revenues to the states, the principle of a dedicated highway fund was brought into being. These funds, used only to support highways, constituted a radical departure from the commonly held idea of all tax revenues going into a general fund to be appropriated for specific governmental functions. The federal government adopted the concept of dedicating highway user taxes with the establishment of the 1956 Federal Highway Act, which set up the Highway Trust Fund.

There are still proponents and opponents to dedicating highway user taxes for a specific purpose. There are many advantages from the highway official's viewpoint but a1so disadvantages from the standpoint of budgeting and finance. More recently, there has been discussion as to the use of dedicated highway funds for transit purposes and other nonhighway activities [34].

Brief History of Indiana Highway Taxation

Indiana became a state in the year 1816 and also in this year the Federal government enacted the Statehood Enabling Act of 1816. This act provided for Federal aid 
to promote highway development and was important to the newly formed State of Indiana. Congress realized the economic and military importance of developing highways traversing the fledgling nation. This act provided for the donation of land to the states, the sale of which was to be used for the generation of highway revenues. The requirements stated that three percent of the proceeds from the sale of the land were to be set aside for local road construction and an additional two percent was to be dedicated to roads providing for the travel of through traffic. This has come to be known as the "Three Percent Fund" and was administered by state agents at the county level [35].

In the year 1836 the Indiana General Assembly passed the Internal Improvement Act. This act was to provide for improved transportation in Indiana by negotiating loans, writing contracts and appropriating money through the auspices of the Internal Improvement Board. But as the result of poor planning, mismanagement and incompetence, the agency went bankrupt and was replaced by a Board of Public Works. The Board of Public Works proved unsuccessful and in 1842 the state government turned road responsibility over to the counties [36].

In 1873 Indiana cities and towns, concerned by increasing road problems, received authority from the state to assess abutting properties to roads and sell bonds in order to support urban roads. Four years later in 1877 , county 
commissioners gained a 1 ike authority to finance roads through property taxation and bonds [37].

The Federal Highway Act of 1916 provided for allocation of Federal aid for state highways on the condition they were administered by a state highway agency. With this in mind, the Indiana State Highway Commission was formed in 1917 to provide construction of "farm to market" roads. The financing of these roads was to come from three sources: (1) proceeds from the inheritence tax, (2) reimbursements from railroads, (3) any general fund appropriations available [38] .

A 1 aw enacted in 1919 called for the State highway system to reach every county seat and all cities over 5,000 in population. This 1 aw was to be financed by property tax, motor vehicle fees and federal aid [39]. It was during the $1920^{\prime}$ s that a reversal started in highway financing policy. New revenue sources were gaining popularity because of the growing number of automobiles. In 1920 , thirty percent of the total highway revenues in Indiana came from automobile registration fees. In 1923 a two cent gasoline tax was added to expanding revenues. During this period the inheritance tax was funneled into the general fund and the property tax was repealed [40] . This made the user taxes the major contributors to the financing of Indiana's highways. 
The Motor Vehicle Highway Account was created in 1937 to combine various revenues into a single dedicated highway fund. This account is the major source of highway funds for the state, county and local highways, roads and streets. The funds from this account are distributed to these jurisdictions according to a single distribution formula. Wore recently the Highway Road and Street Fund was established to collect the 1969 two cent fuel tax increase. From this fund money is distributed to the Local Road and Street Account and the Primary system Special Account. These Accounts supply financing for engineering and construction on arterial and Federal Aid Primary streets and highways. 


\section{CHAPTER I I I \\ FINANCING OF STATE HIGHWAYS IN INDIANA}

The responsibility for the planning, design, construction and maintenance of the Indiana highway system is divided among the State Highway Commission, the 92 Indiana counties, and Indiana cities and towns. The jurisdictions and corresponding mileage, are shown in Table 3 .

Table 3

Jurisdiction of Indiana Highway Mileage

Jurisdiction

Mileage

Indiana State Highway System

11,451

Under County Jurisdiction

65,276

Indiana's Cities and Towns

14,613

Source: Highway Statistics, 1974 .

The state highway system consists of 11,451 miles and carries 60 percent of the states total travel [41]. In the state highway system, 10,056 miles constitute the State's primary system in rural mileage and 1,238 miles are extensions of the State's primary system in urban 
areas [42]. The State llighray Commission also maintains roads within the state parks and institutions.

\section{The Motor Vehicle Highway Account}

As mentioned in Chapter 2, Indiana's General Assembly of 1937 passed legislation creating a dedicated highway fund called the Motor Vehicle Highway Account. Revenue from motor vehicle registration fees, gasoline taxes, and other miscellaneous sources of user revenue are collected into this account. This money is then authorized to be distributed according to a formula set down by the legislature to the State, Counties and Cities for the support of highways, roads and streets in Indiana.

Revenue placed into the Motor Vehicle Highway Account originates from a variety of highway related taxes. Figure 5 shows the receipts and disbursements into the Account. There is a variety of sources which are responsible for revenue collection and deposit into the Account. However, it is from just two major sources of revenue that over 95 percent of the gross receipts are obtained. These two major sources are the motor fuel tax and motor vehicle registration.

These dedicated highway taxes are collected for the Motor Vehicle Account by various departments of the state. The Department of Revenue collects the motor fuel tax and dealer and distributor licenses. The Bureau of Motor Vehicles handles the revenues received from vehicle 


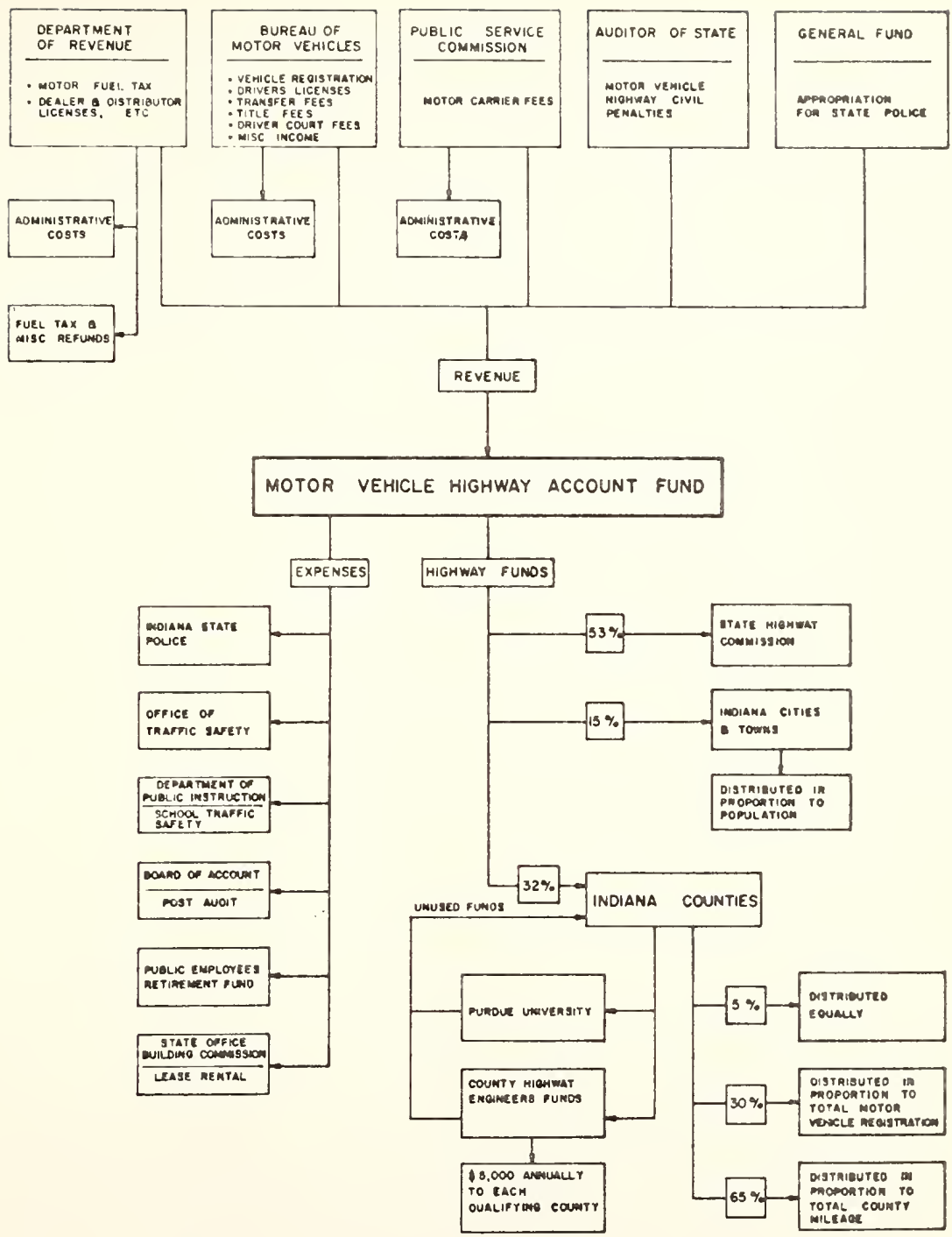

FIGURE 5. MOTOR VEHICLE HIGHWAY ACCOUNT. 
registrations and licensing, drivers license fees, and title and transfer fees. The Public Service Commission collects motor carrier fees and civil penalties relating to highways are provided by the Auditor of the State. Fifty percent of the appropriation for the State Police comes from the State General Fund and goes into the Motor Vehicle Account, although the specific percentage contributed has varied considerably over the past years.

Motor fuel taxes paid on fuel purchased for other than highway use are refunded from the gross receipts of the Account. Currently, the motor fuel refunds are $2-3$ percent of the gross revenues.

of primary concern is not the gross revenues but the net amount available for distribution to the State, Counties and Cities. The net amount available for distribution is arrived at by a deduction of certain administrative expenses. These disbursements prior to distribution are for such things as: the State Police, Office of Traffic Safety, Department of Public Instruction, Board of Accountants, Public Employees Retirement Fund, and the State Office Building Commission, which all provide supporting or supplementary service to the function of the State's roads and highways. After the subtraction of these expenses, the remaining funds constitute the net revenue available for distribution to the State, County and other local highway jurisdictions. 
Distribution of the Motor Vehicle Highway Account

The funds available from the Motor Vehicle Highway

Accounts are distributed to the respective jurisdictions according to a formula specified by the Indiana legislature. This formula currently allocates 53 percent of the funds available for distribution to the state highway system, 32 percent to the County highways and 15 percent to the cities and towns. Because of increasing trave1, the amount distributed from the Account to the jurisdictions has been growing slightly each year. From 1970 to 1975 the amount distributed to each of these jurisdictions has increased 1.5 percent per year during this period [43].

The total money apportioned to the counties is distributed among the counties in the following manner:

$5 \%$ is distributed on an equal basis,

$30 \%$ is distributed in proportion to the total county motor vehicle registrations,

65\% is distributed in proportion to the total county highway mileage.

The distribution among the cities and towns is by population according to the 1 ast preceding U. S. Census.

\section{Special Accounts}

The 1969 General Assembly of Indiana passed legislation to increase the state motor fuel tax by two cents per gallon. This increased the total fuel tax to eight cents per gallon. The revenue generated from this two cent increase was not to go into the Motor Vehicle Highway 
Account but into three separate accounts as discusscd below.

In the Highway Road and strect lumb aro placed all the revenues generated by the two cent fuel tax increase. The money from this Fund is then divided into two other accounts before being distributed to the State and County highway jurisdictions. These two accounts are the Primary Highway System Special Account and the Local Road and Street Account.

The Primary Highway System Special Account was established for engineering, 1 and aquisition, and construction of highway projects for the State Federal-Aid Primary System. Fifty-five percent of the Highway Road and Street Fund is deposited into this Account for use by the State Highway Commission.

The Local Road and Street Account is funded with the remaining 45 percent of the Highway Road and Street Fund. This account is to be used exclusively by cities, towns, and counties for engineering, land aquisition, reconstruction and construction of the arterial street and road system. It may also be used for the construction or repair of bridges. This account is distributed to counties according to the ratio of passenger car registrations in a county to total passenger car registrations in the state. The sub-allocation between the cities within a particular county is as follows: 


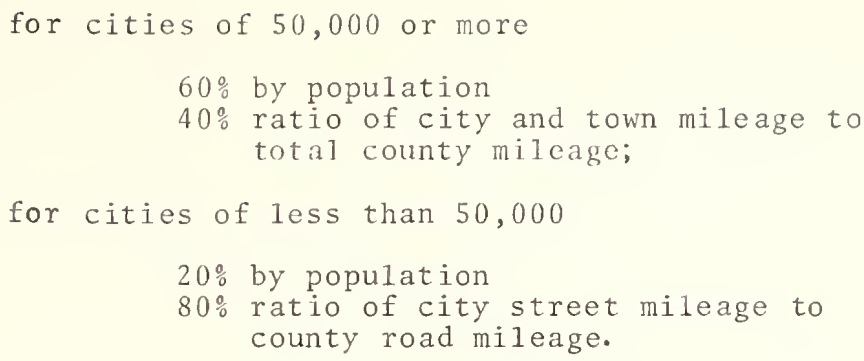

\section{Activity in the Motor Vehicle Highway Account}

During the period 1971-75 revenues to the Motor Vehicle Highway Account have increased 7.3 percent. During this same period the administrative expenses for the Account, Bureau of Motor Vehicles, State Police, Motor Vehicle Inspection, Traffic Safety Commission and miscellaneous expenses, have increased a total of 65.6 percent [44]. This represents rising salary and personnel needs required to administer the Motor Vehicle Highway Account. Table 4 indicates the magnitude of increase in operating expenses for this period.

Table 4

Motor Vehicle Highway Account Operating Expenses, 1971-1975

Source

Percent Increase 1971-1975

Bureau of Motor Vehicles $70 \%$

State Police and Motor Vehicle Inspection $65 \%$

Traffic Safety Commission $7 \%$

Motor Fue 1 Division of Revenue $69 \%$ 
The fiscal activity in the Motor Vehicle II ghway Account for 1975 is shown in Table 5. The motor fue 1

tax and the motor vehicle license fees contributed 97 percent of the total revenue for this year.

Also of interest is the increase in revenues received by the State, County and other local highway jurisclictions during the last five years which were used for construction and maintenance of Indiana highways. Table 6 shows the increase in revenues distributed to these jurisdictions. While most of this money, used primarily for construction purposes, has increased 7 to 8 percent, the construction cost index has jumped 50 percent.

Table 6

Mntor Vehicle Highway Account Disbursements, 1970-1975

F.Y. 1970

(militions)
F.Y. 1975

(millions)
$\%$ increase

Cities and Towns

28.6

61.0

30.9

8.0

Counties

101.2

65.7

7.7

State Uighway

109.5

8.2

Source: Indiana State Highway Commission [45].

The Motor Vehicle Highway Account has been the major revenue source for State and County highways, roads, and streets. In addition to these funds there are a number of supplementary sources of highliay revenue. The State administered highways received an estimated 41 percent of 
Table 5

Fiscal Activity in the Motor Vehicle Highway Account 1975

Revenue

Motor Fuel Tax

Gas Tax Refund

Motor Vehicle Licenses

Gen. Fund-State Police

Federal Reimbursements

Vehicle Inspection Fees

Driver Court Fees

Purdue-Co. Hwy. Research

Excess PSI Funds

Re-Instatement Fees

Misc.

Disbursements Prior to Distribution

Bureau of Motor Vehicles

State Police and Motor Veh. Inspection

Traffic and Safety Commission

Motor Fuel Division

Misc.
Thousands of Dollars

$$
\begin{array}{r}
185,745.4 \\
(5,435.4) \\
59,925.9 \\
7,125.7 \\
1,816.1 \\
1,679.5 \\
1,048.1 \\
156.7 \\
703.7 \\
59.6 \\
335.9 \\
\hline 253,160.6
\end{array}
$$

Source: Indiana State Highway Commission 
their total revenues from Federal funds which are apportioned according to formula from the Federal Highway Trust Fund [46]. Appendix A summarizes the Federal Aid expenditures to Indiana in recent years. The Motor Vehicle Highway Account also contributes 80 percent of the total county highway revenues. County Commissioners are authorized by the state to establish a "cumulative bridge fund" with the proceeds of a county-wide property tax levy. This fund is to be used for maintenance and construction of county highway bridges. Federal-Aid Secondary Funds are another source of revenue to the counties. Federal regulations require one-half of the Federal-Aid Secondary Funds apportioned to the state be made available for county highway departments for construction on county Federal-Aid routes. Cities and towns receive 48 percent of their total revenues from the Motor Vehicle Highway Account. Property tax and general fund appropriations are the major revenue contributors supplying 49 percent of al1 street fund [47].

Since its conception in 1937, the Motor Vehicle Highway Account has served as the major depository for Indiana highway user revenues. Motor fuel taxes and vehicle registrations are expected to continue to be the major contributors to this Account. 
CHAPTER IV

A SURVEY OF STATE HIGHWAY FINANCING IN THE UNITED STATES

To furnish information on the principal sources of state highway revenue throughout the country and to put in perspective Indiana's fuel taxation and vehicle registration policies, a questionnaire survey was conducted to review the various means used by the other states for financing their highway system. This chapter is a synopsis of the results of that survey.

\section{The Questionnaire}

The two-page questionnaire sent to the fifty states was comprised of eleven questions involving state highway financing. The questions were concerned with the topics of; state highway revenue sources, gasoline, diesel and special fuels taxation rates, taxation of fuel used in governmental vehicles, registration fees for passenger cars and trucks, and pending or proposed legislation for increasing highway revenues. The short two-page format, as opposed to a lengthy survey was designed to make sure that the questions could be answered in short time and without much effort. 
A total of 47 states or 94 percent of the State Highway agencies responded. Appendix B contains a sample questionnaire and a tabulated summary of replies.

\section{Summary of Responses}

As previously mentioned, 47 states responded to the questionnaire which was much higher than anticipated. The replies were concise and complete for the most part and many states provided additional information which proved extremely useful to this research. In the following paragraphs the major findings of this survey are discussed.

Sources of State Highway Revenue

The majority of states ( 83 percent) collect road user and other miscellaneous tax revenues in a dedicated highway or road fund. These dedicated funds are used solely for highway purposes. Some states like Illinois, have initiated a Transportation Fund supported by highway and general fund revenues. In this situation, highways compete with other transportation modes for financing priorities. State highways relying on state general fund support must vie for funding, usually on a yearly basis, with all other governmental priorities. Table 7 indicates the number of state highways having dedicated, transportation or general fund support. 
Table 7

Types of Highway Fund Support - 1976

Type of Fund

Number of States

Dedicated Highway Fund

Transportation Fund

State Genera1 Fund

5

The states of Alaska, Delaware, New York, New Jersey, and Rhode Island are funded through a general fund and Maryland, Connecticut and Illinois have transportation funds from which highways receive funding.

Whatever the type of fund utilized by a particular state, it is of interest to examine the specific sources of user revenue contributing to these funds. Highway user tax revenue is the primary source of revenue for all highways. This revenue comes from a variety of origins: motor fuel tax, registration and license fees, motor carrier fees, title fees, toll revenue and a number of other miscellaneous user imposts. The number of states employing a specific revenue source are tabulated in Table 8 , according to the information supplied by the states. 
Table 8

Specific State Highway Revenue Sources

Fuel Tax

47

Vehicle Registrations 46

Drivers License, Title,

Transfer \& Misc. Fees

Motor Carrier Fees

Weight Distance Fees

Gross Receipts Tax

Sales Tax (Vehicles \& Parts)

Roadside Advertising Fees

Cigarette Tax

Vehicle Insurance Tax
12

25

1

The fucl tax and vehicle registration revenues account for the major protion of user funds for the state highways. In Indiana, these two revenues account for an average of 90 percent of the total user revenues generated in the state. Consequently, this study examined the possibility of raising additional revenues by adjusting the motor fuel tax and vehicle registration and licensing fees. Table 9 shows the relationships of state and Federal user taxes as compared to the total receipts for selected state highways. On the average the motor fuel and motor vehicle taxes provide state highways with 91 percent of the total receipts used for the construction and maintenance of these 


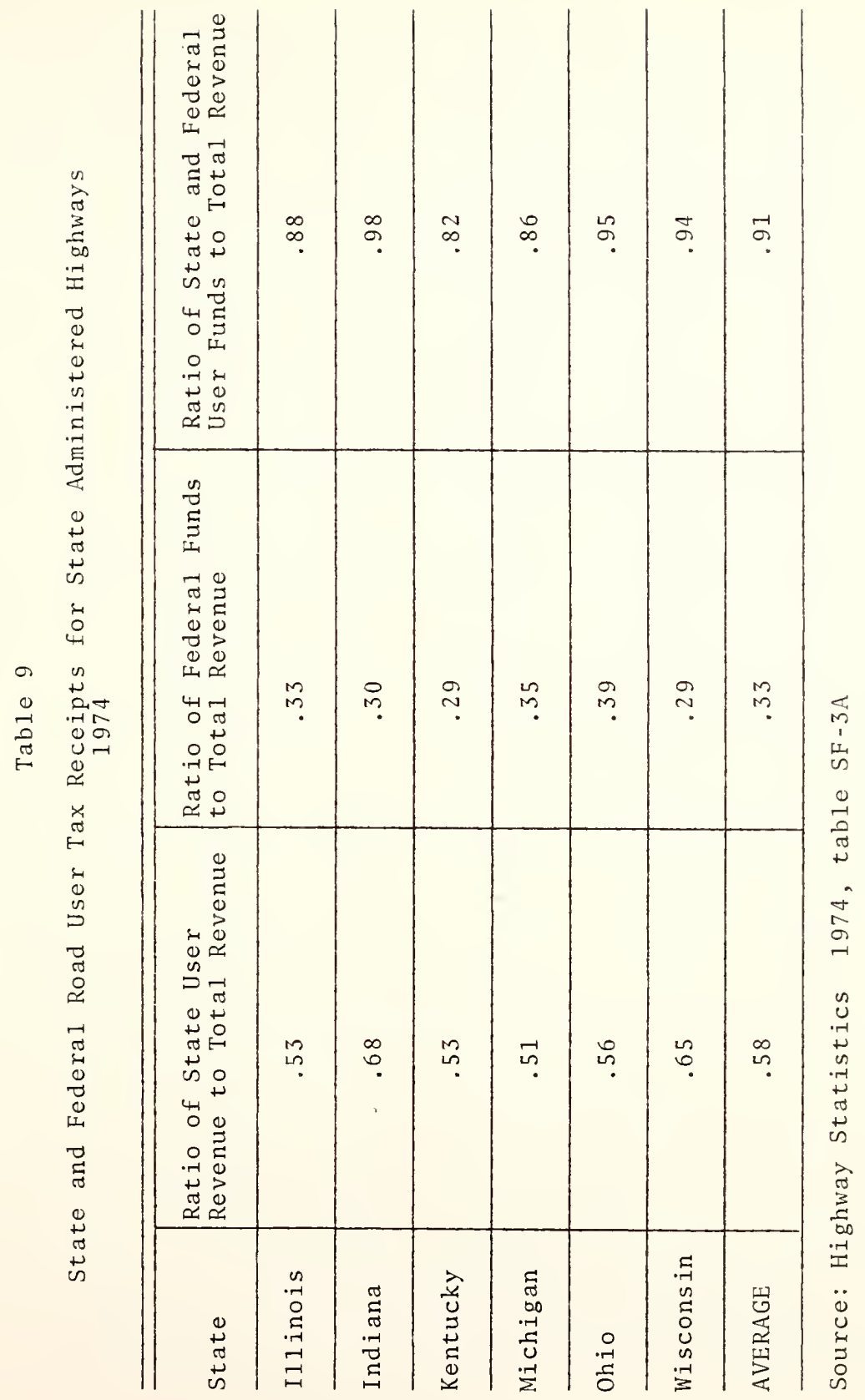


highways. Of this 91 percent, 58 percent comes directly from State collected user revenues and 33 percent comes from the Federal highway user taxes. The remaining 9 percent comes from the issuance of bonds, general fund appropriations or miscellaneous receipts.

In summary, most states ( 83 percent) use the idea of a dedicated highway fund supported by various highway user taxes to finance highways. Although fuel tax and vehicle registration fees provide most of the revenue, a significant number of states use many additional sources including sales tax on vehicles and parts to raise revenues.

\section{Motor Fuel Taxation}

Gasoline. The gasoline tax has become the major revenue for the construction and maintenance of highways. The most common type of gasoline tax is the flat rate or per gallon tax. Two other types of taxation are the sales tax and the ad valorem tax both of which are not commonly used. Table 10 summarizes the number of states using the per gallon tax, sales tax, and ad valorem tax. 
Table 10

Gasoline Taxation Methods

\begin{tabular}{lccc} 
Type of Tax & $\begin{array}{c}\text { Number of } \\
\text { States }\end{array}$ & $\begin{array}{c}\text { U.S. Average } \\
\text { rate }\end{array}$ & Range \\
\hline Per Gallon Tax & 47 & $8 \phi$ & $5-11 \phi$ \\
Sales Tax & $3^{*}$ & $5 \%$ & $4-6 \%$ \\
Ad Valorem Tax & 9 under consideration & \\
\hline
\end{tabular}

All states replying have a per gallon tax on gasoline and three states responding indicated an additional sales tax of 4 to 6 percent*. However, in all cases this sales tax revenue goes directly to the general fund and is not set aside for highway purposes. While no states have implemented an ad valorem tax, several states are seriously considering the possibilities and advantages such a tax represents.

Figure 6 is a histogram of gasoline tax rates set by the various states. While the national average is 8 cents, the majority of states ( 57 percent) have rates set at either 7 or 9 cents. The range of tax rates is from a 5 cent per gallon tax in Texas to an 11 cent tax recently implemented in Connecticut.

It is also of interest to examine the last year in which a state raised its fuel tax rate. A comparison with * Although Mississippi, California, and Indiana have a sales tax on motor fuel none of this money is earmarked for highway purposes. 


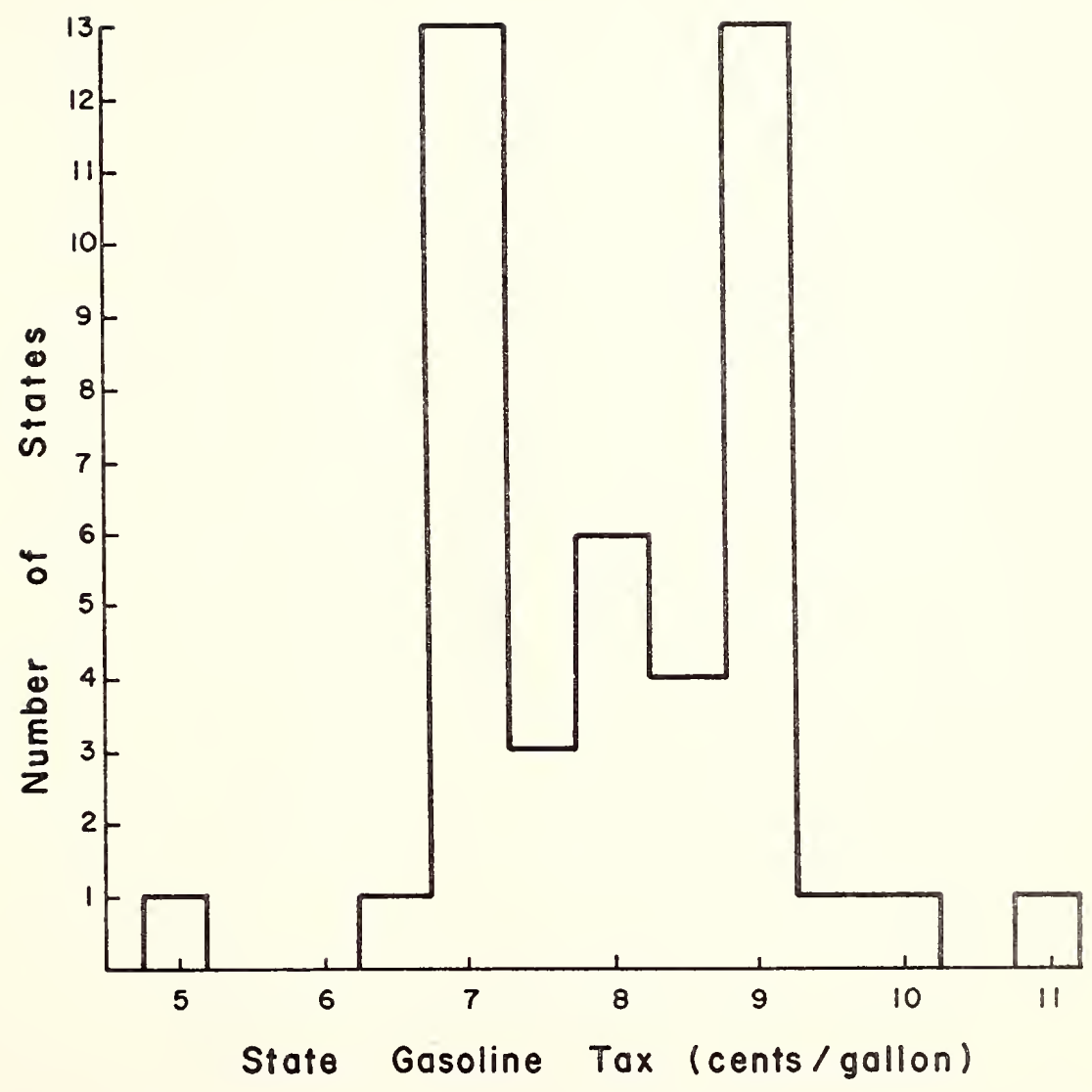

FIGURE 6 . CURRENT STATE GASOLINE TAX 
past records would then reveal any trend toward more frequent raising of rates to cope with inflationary pressures. Table 11 examines the number of states that have legislated changes within the past three years.

Table 11

Legislative Changes in the Gasoline Tax

\begin{tabular}{|c|c|c|c|}
\hline \multicolumn{2}{|c|}{$\begin{array}{l}\text { Gasoline Tax Rate } \\
\text { Changed Within the } \\
\text { Past Three Years }\end{array}$} & \multicolumn{2}{|c|}{$\begin{array}{l}\text { States With Imminent } \\
\text { or Pending Legislation } \\
\text { Regarding Gas Tax }\end{array}$} \\
\hline $\begin{array}{l}\text { Number of } \\
\text { States }\end{array}$ & $\begin{array}{l}\% \text { of } \\
\text { Respondents }\end{array}$ & $\begin{array}{l}\text { Number of } \\
\text { States }\end{array}$ & $\begin{array}{l}\% \text { of } \\
\text { Respondents }\end{array}$ \\
\hline 14 & $30 \%$ & 12 & $26 \%$ \\
\hline
\end{tabular}

Fourteen states or 30 percent of the respondents have raised their gasoline tax in the past three years. This information in addition to a study done by the Texas Highway Department illustrates conclusively that from 1969 to 1976 an unusually large number of states (72 percent). have increased fuel tax rates. Figure 7 shows this development over time. It is also interesting that 18 states, which did not indicate any fuel tax or other legislation to increase revenues under consideration, conveyed the fact that they may fall into serious cash-flow problems in the next few years. They did mention however, that some study was being done on the subject of highway 


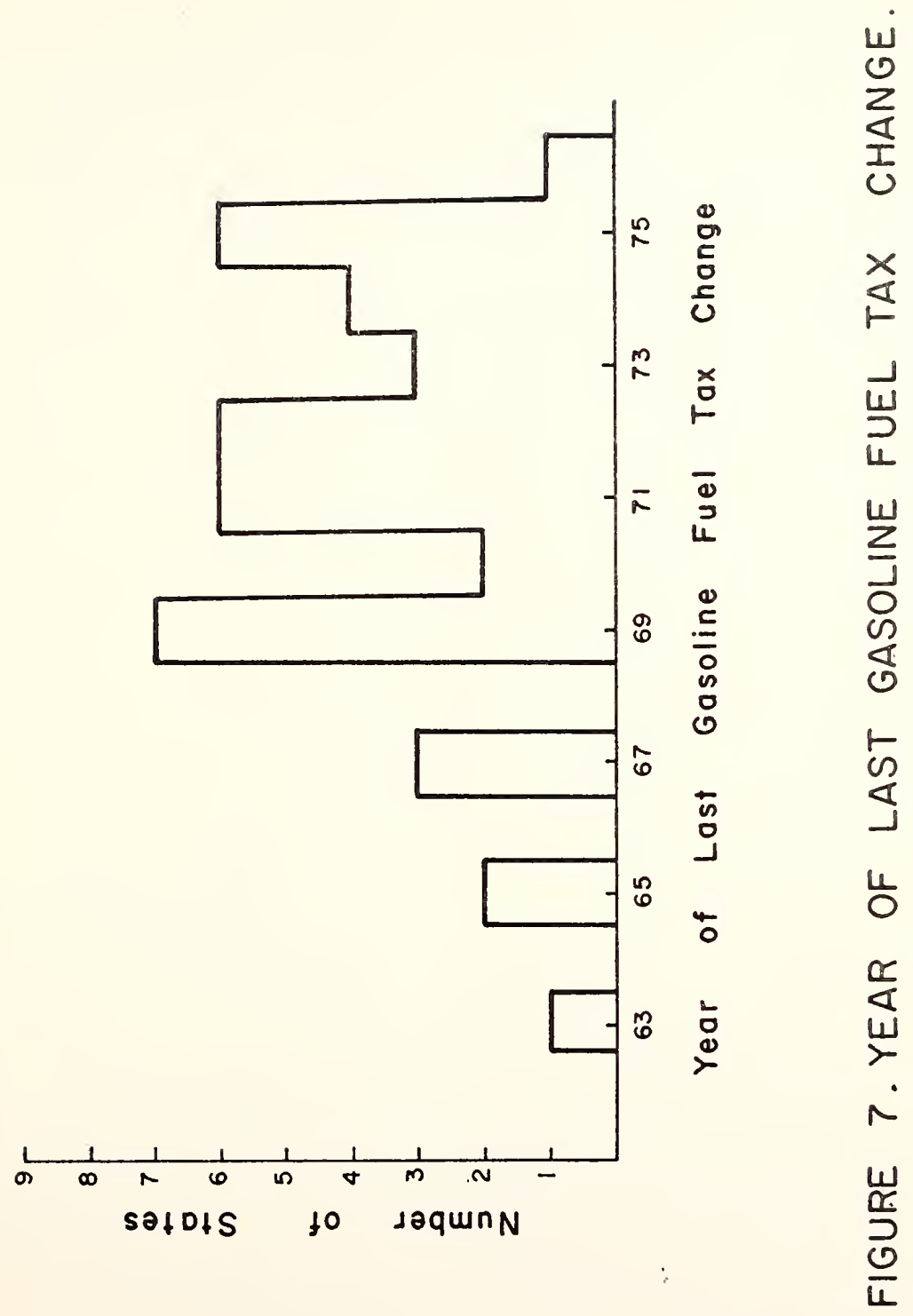


revenues and taxation. It can therefore be concluded that almost all of the state highway agencies are feeling the pressure of declining tax revenues and increasing inflation effects. Sore legislative involvement in the area of highway finance is reeded on a continuing basis if highways are to have adequate revenues.

Diesel fuel Tax. The responses regarding diesel fuel taxation among the states is tabulated in Table 12. All states except Vermont have a tax on diesel fuel with twenty percent of those responding having diesel tax rates higher than gasoline rates.

Table 12

Diese1 Fue1 Tax Rates

$\begin{array}{lll}\text { Diese1 Rate } & \text { Diese1 Rate } & \text { Diese1 Rate } \\ \text { Lower Than } & \text { Same As } & \text { Higher Than } \\ \text { Gasoline } & \text { Gasoline } & \text { Gasoline }\end{array}$

Number of States

2

35

10

Average Rate

(cents/gallon)

6.75

8.25

8.58

For those states having a diesel tax higher than gasoline, the average tax is 9.25 cents with the range between 9 and 10 cents. Two states, Michigan and Ok1ahoma, have a diesel tax rate less than their respective gasoline tax rates. However, Michigan has indicated that an increase in the diesel fue 1 rate, making it equal to the gasoline 
rate, should be forthcoming in the next legislative session. Oklahoma's diesel fuel tax differential is minute and of no real significant interest.

Seventy-four percent of the states have a diesel fuel tax rate equal to their current gasoline tax rate. A1though there have been many arguments for an increased diesel fuel tax higher than the gas tax,* the majority of states choose to tax diesel fuel and gasoline at the same rate. The question here is, are the highway user costs being distributed in the most equitable manner among vehicle types? If two trucks are exactly the same except one has a diesel engine and one has a gasoline engine, the question here becomes: Should the diesel truck pay more tax on fuel because it travels further on one gallon than the gasoline truck? Each state must examine its distribution of the cost burden to determine if a diesel fuel tax differential is applicable.

Special Fue1s. Those fuels other than gasoline which are used in motor vehicles are commonly referred to as special fuels. In 1974, these special fuels accounted for 9 percent of the total gallonage of motor fuel subject to state taxation. In this study special fuels will refer to those fuels other than gasoline or diesel fuel, which are used in highway travel. There are seven states which do not * See Thomas R. Swartz, "The Economics of the Diesel Fue1 Tax Differential", Highway Research Record No. 285, Highway Research Board. 
tax special fuels but six of these states tax diesel fuel. The special fuels are usually taxed at a rate slightly less than that of diesel fuels, although not enough states responded to this portion of the question to provide any statistics. Seventeen states tax gasoline, diesel, and special fuels at the same rate. Thirteen states indicated they had current or pending legislation in their state regarding diesel and special fuels tax rates.

Fuel Tax For Governmental Vehicles. Twenty-nine states or 63 percent responding have state and local governmental vehicles pay the state gasoline tax. Indiana does not currently require state and local vehicles to pay the state fuel tax. However, the number of vehicles this taxation would involve is small and would not generate any significant revenues.

\section{Registration Fees}

As mentioned previously, one of the principal sources of highway user revenue is the motor vehicle registration. To examine more closely the rates and types of fees other states are presently using, questions were asked regarding automobile and truck registrations.

Automobile Registration Fees. In order to provide equitable distribution of the road user costs a number of different criteria are used by the various states as the basis for automobile registration. The most popular basis for registration continues to be the flat fee. This means 
there is one flat fee charged regardless of size, weight, or value of the vehicle. Figure 8 shows the flat fees used by selected states. Nineteen states in all have a basic flat fee for automobile registration. The national average flat fee is $\$ 14.28$ per year with a low of $\$ 3.00$ per year in Louisiana and a high of $\$ 32.00$ per year in Vermont. The percentages of states using fees other than flat fees are shown in Table 13.

Table 13

Automobile Registration Criterion

Fee Basis

Percentage of States

Using this Basis
Fee for a

Typical Vehicle*
Flat Fee

Empty Weight

Age and Empty

Weight

other Combinations
$39 \%$

28

7

26
$\$ 14.28$

21.91

24.56

31.54

*Source: Highway Statistics, 1974

Although the flat fee is the most popular registration basis it yields the lowest revenue for a typical vehicle when compared to other basis for registration. The more complex the registration criteria, the greater revenues it seems to bring in, sometimes twice as much as the flat rates. It is very difficult to compare registration fees on an equal basis as each state follows what it considers an equitable distribution of costs. 


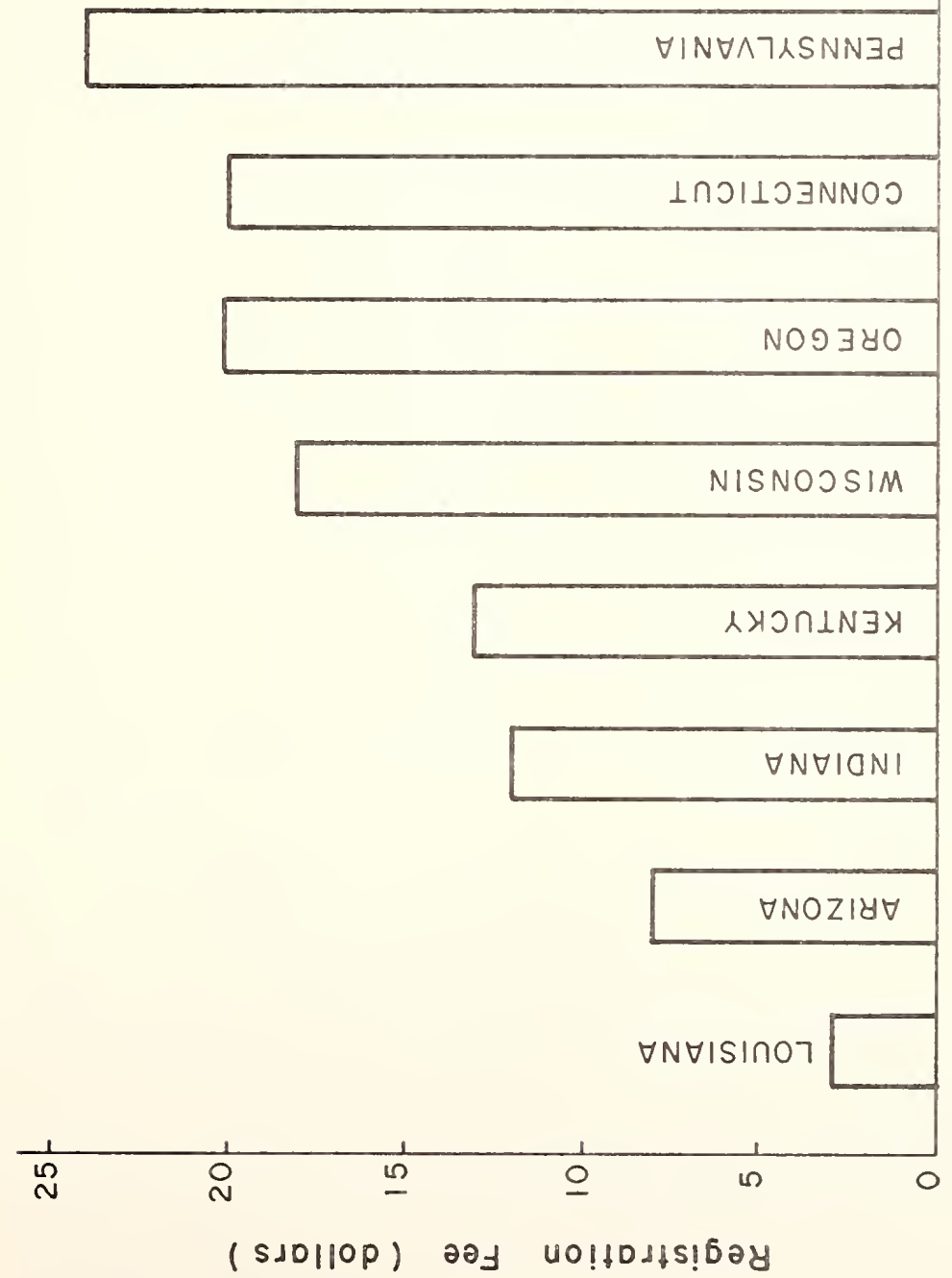

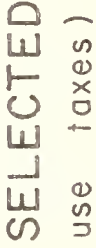

แل

4

0
$-\frac{1}{0}$
-1
0
0

4

7

0 응

E

$\bar{\sigma}$

$\propto$

$\leftarrow$

(s)

동

(1) ฉ

w

党

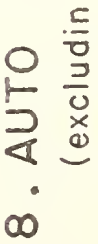

$\frac{4}{\frac{4}{2}}$ 


\section{Truck and Tractor-Trailer Registration}

Since the construction and maintenance cost of highways increases with the load they must support, any extra costs should be assessed to the heavier vehicles. It is for this reason that most trucks or truck-trailer combinations are registered by a flat fee plus an additional fee proportional to some truck weight criteria. The gross weight of the vehicle is the usual method of determining these costs. Seventy percent of the states use gross weight as the criterion for registration, however, axle weight, unladen or empty weight, age and rated capacity are used in various combinations in other states. The myriad of different regulations regarding single-unit, tractor trucks and semitrailers by the various states makes a realistic comparison difficult. An excellent summary of truck registration fees for each state can be found in Highway Statistics, published by the U. S. Department of Transportation.

\section{Efforts to Raise Additional Revenue}

In response to the question on additional revenue many states mentioned various possible revenue sources and taxation policies. Many of these additional user taxation policies represent the reflection of current economic and social pressures. Such policies must be fully evaluated by decision makers before they are adopted as an additional revenue source. However, after 
careful evaluation, these revenue sources may provide additional revenue or substitutes for traditional revenue sources.

One case of note is the ad valorem taxation of fuel. States such as Oregon, Utah, California, and Alabama along with others, are proposing in various forms, an escalating, sliding or ad valorem tax to be placed on motor fuel. This type of fuel tax keeps pace with inflationary pressure and provides additional needed revenues without the delays sometimes encountered through legislative channels. As this subject warrants a more detailed discussion, the feasibility of an ad valorem tax is explored in Chapter $V$. In Table 14 are summarized some of the additional revenue types mentioned by a selected group of states.

\section{Commentary}

This section is designed to respond to one question; how well do the present Indiana taxation policies regarding highways compare to those of other states? The answers to this question are important because they will indicate the possible courses of action that Indiana can undertake to meet its needed additional revenue for state highway financing.

The per gallon fuel tax rate for motor fuels in Indiana is compared with the national averages in Table 15. Although Indiana's fuel tax rates are close to the national average, it is still possible to raise additional revenues 
Tab1e 14

Noteworthy Sources of Highway Revenue-Selected States

State

Observation of Interest

Hawaii

A 10 cents per 100 cubic inch engine displacement tax will soon become law.

Illinois

Passenger car registration is a flat fee which is based upon two horsepower groupings.

Indiana

A 4 percent sales tax is placed on gasoline but no funds go specifically to highways.

Iowa

A 3 percent use tax is placed on the sale of new and used vehicles. In 1975 the state highways received $\$ 36.7$ million from this source.

Kentucky

Mississippi

Oregon This state has a surtax (2cents/gal.) on motor fuel consumed by vehicles having three or more axles.

A 5 percent sales tax is placed on the retail price of gasoline. Again, all funds go into the general fund. Electric vehicles are registered separately from internal combustion engines. Registration fee is $\$ 50.00$ for two years.

Wyoming This state is fortunate enough to receive over \$12 million per year for state highways from mineral royalties. 
through increased fuel taxation in Indiana. In fact Indiana, along with 56 percent of the states who have recently or are studying the questions of increasing costs, must seriously consider alternatives to increase its highway revenues. Chapter VI will establish this need for additional revenues in more detail.

Table 15

Fuel Tax Rates-Indiana and U. S.

\begin{tabular}{l|c|c}
\hline $\begin{array}{l}\text { Fuel Tax } \\
\text { (cents per gallon) }\end{array}$ & U.S. Average & Indiana \\
\hline $\begin{array}{l}\text { Gasoline } \\
\text { Diesel and Special } \\
\text { Fuels }\end{array}$ & 8.25 & 8.0 \\
\hline
\end{tabular}

Gasoline and diesel fuel rates for selected states are shown in Figure 9. There is no direct correlation between total state mileage and the rate at which motor fuel is taxed. The motor fuel tax rate correlates with the responsibilities given and the services provided by the corresponding Highway Departments or Departments of Transportation. 


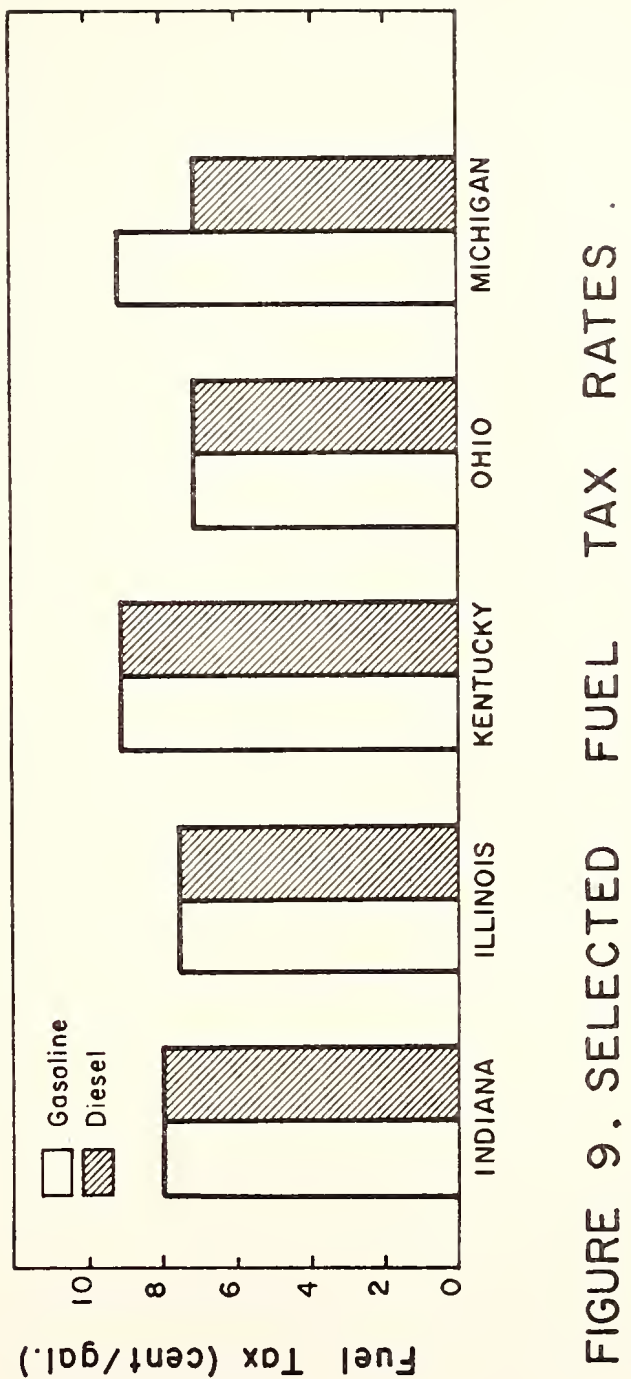


Indiana's automobile registration fec is currently a flat $\$ 12.25$ per year. Additionally, an excise tax is placed on all passenger cars, motorcycles and trucks with a declared gross weight not excecding 11,000 pounds, and is paid with the registration fec. This excise tax is in lieu of personal property tax on motor vehicles. The revenues gencrated by the excisc tax do not go for highway support but are general fund revenues. Table 16 shows registration fees for a typical vehicle in Indiana and surrounding states.

Table 17 represents a summary of motor vehicle registration fees for tractor-trailers, scmi-trailers and combinations for selected states. The wide variation in fees among the several states can be noted. The reason for this variation is the method used by the states in determining the uscr tax distribution. Many factors such as total mileage, vehicle miles of travel, and how each jurisdiction is funded are all important in determining equitable taxation policies for any particular state.

In general Indiana has the second lowest motor truck registration fees among the six midwestern states. It should be noted, however, that ohio imposes an additional fee on the basis of ton miles. Therefore it appears that the motor truck registration fecs in Indiana can be increased considerably to raise additional revenues.

In Table 18 is shown a comparison of state highway user 
Table 16

Summary of State Automobile Registration Fee Schedules

\begin{tabular}{|c|c|c|c|}
\hline Fee Basis & $\begin{array}{l}\text { Approximate } \\
\text { From }\end{array}$ & $\begin{array}{l}\text { Range } \\
\text { To }\end{array}$ & $\begin{array}{l}\text { Fee For } \\
\text { Typical } \\
\text { Vehicle }\end{array}$ \\
\hline $\begin{array}{l}\text { I11inois } \\
\text { Horsepower Groups }\end{array}$ & $\$ 18.00$ & $\$ 30.00$ & $\$ 30.00$ \\
\hline $\begin{array}{l}\text { Indiana } \\
\text { Flat Fee Plus } \\
\text { Excise Tax }\end{array}$ & $\begin{array}{l}12.25 \\
12.00\end{array}$ & $\begin{array}{r}12.25 \\
400.00\end{array}$ & $\begin{array}{l}12.25 \\
36.00\end{array}$ \\
\hline $\begin{array}{l}\text { Kentucky } \\
\text { F1at Fee }\end{array}$ & 12.50 & 12.50 & 12.50 \\
\hline $\begin{array}{l}\text { Michigan } \\
\text { Empty Weight }\end{array}$ & 12.00 & 26.95 & 19.25 \\
\hline $\begin{array}{l}\text { Ohio } \\
\text { Flat Fee }\end{array}$ & 10.50 & 10.50 & 10.50 \\
\hline $\begin{array}{l}\text { Wisconsin } \\
\text { Flat Fee }\end{array}$ & 18.00 & 18.00 & 18.00 \\
\hline
\end{tabular}

Source: Highway Statistics, 1974 . 


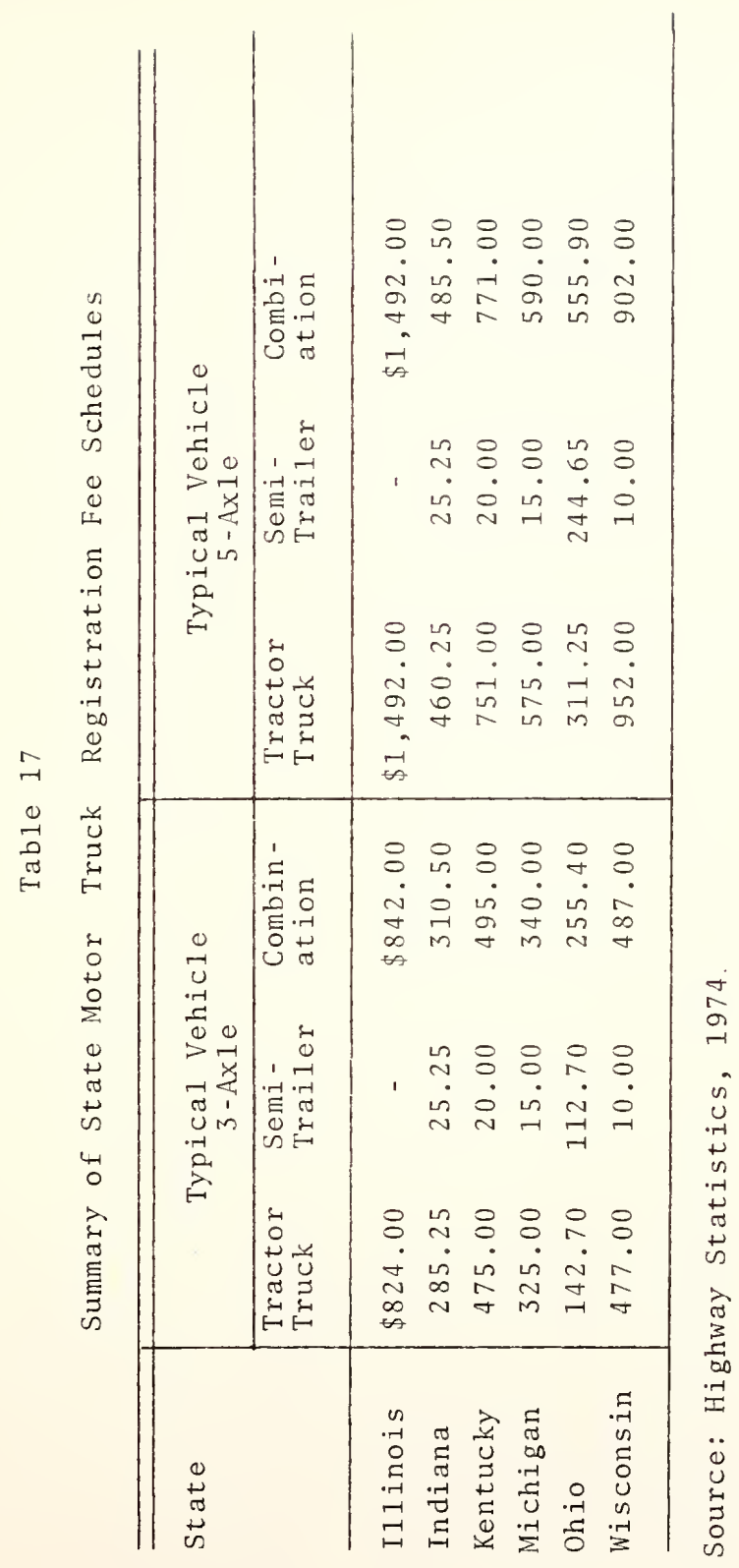




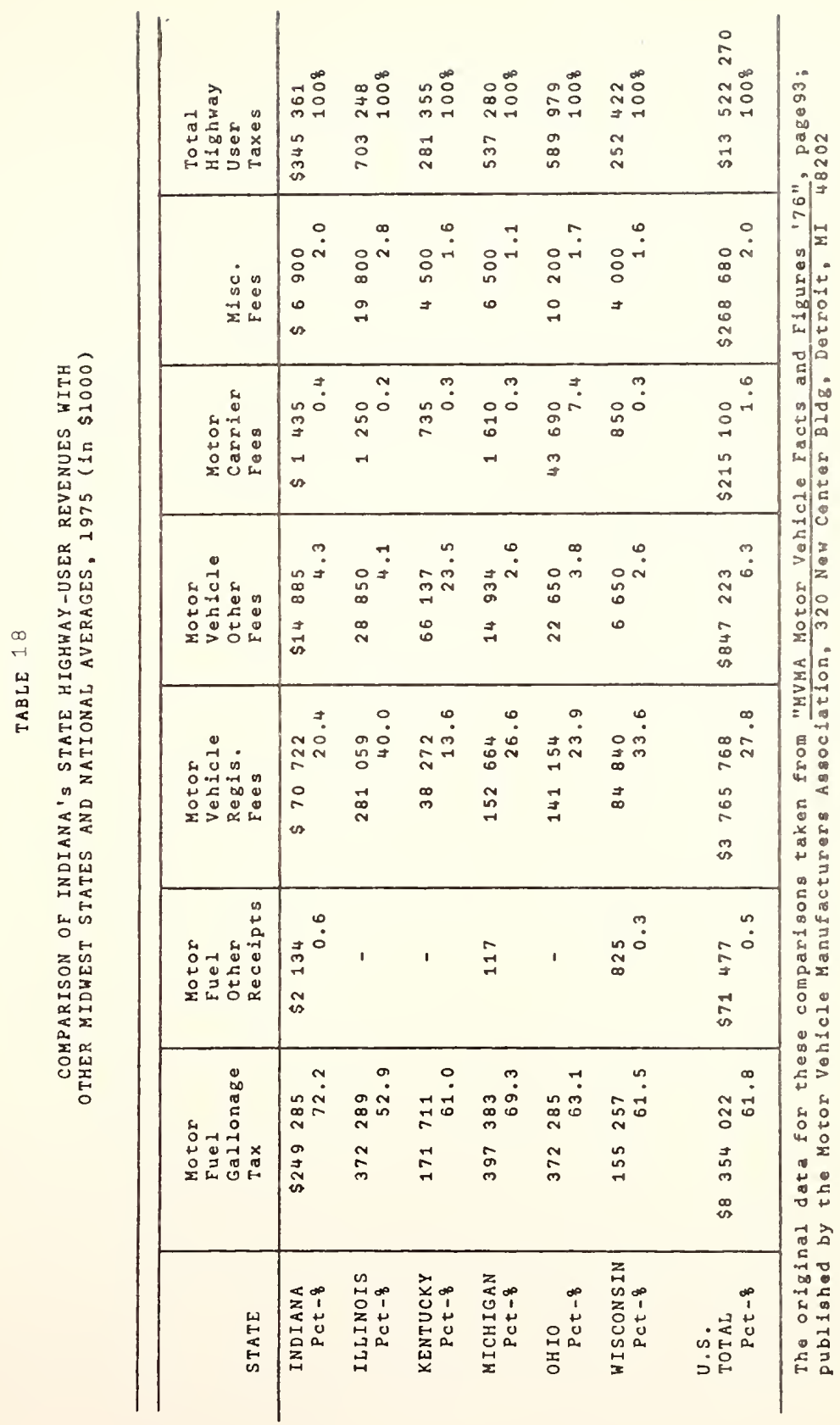


revenues for each state as a percentage of total highway user revenues. Nationally, motor vehicle registration fees account for 27.8 percent of the total highway user taxes. Indiana's registration fees account for only 20.4 percent of its total highway user revenue. In Indiana it can also be seen that motor fuel taxes account for much more of the total revenue than is the national average. It can be concluded that Indiana registration and motor carrier fees should be adjusted upwards to comply with national averages. This Table becomes an important reference for Chapter 6 , which provides alternative taxing proposals.

Table 19 provides information regarding mileage and percentages of revenue distributed to each highway jurisdiction. In many cases the mileage in the state system receives the largest portion of the user revenue, over 50 percent. While this seems inequitable at first, further examination reveals that state mileage, though small, consists of high volume, high speed facilities which carry the majority of the total vehicle miles of trave1. In addition, many State Highway Departments provide assistance and services to County and Local jurisdictions which may not have the technical expertise or the facilities required for certain situations.

Another comparison of interest is the expenditures per vehicle mile of travel for state highway maintenance. Figure 10 shows the expenditures per 1000 vehicle miles of trave1 for selected states. Indiana rates second lowest 


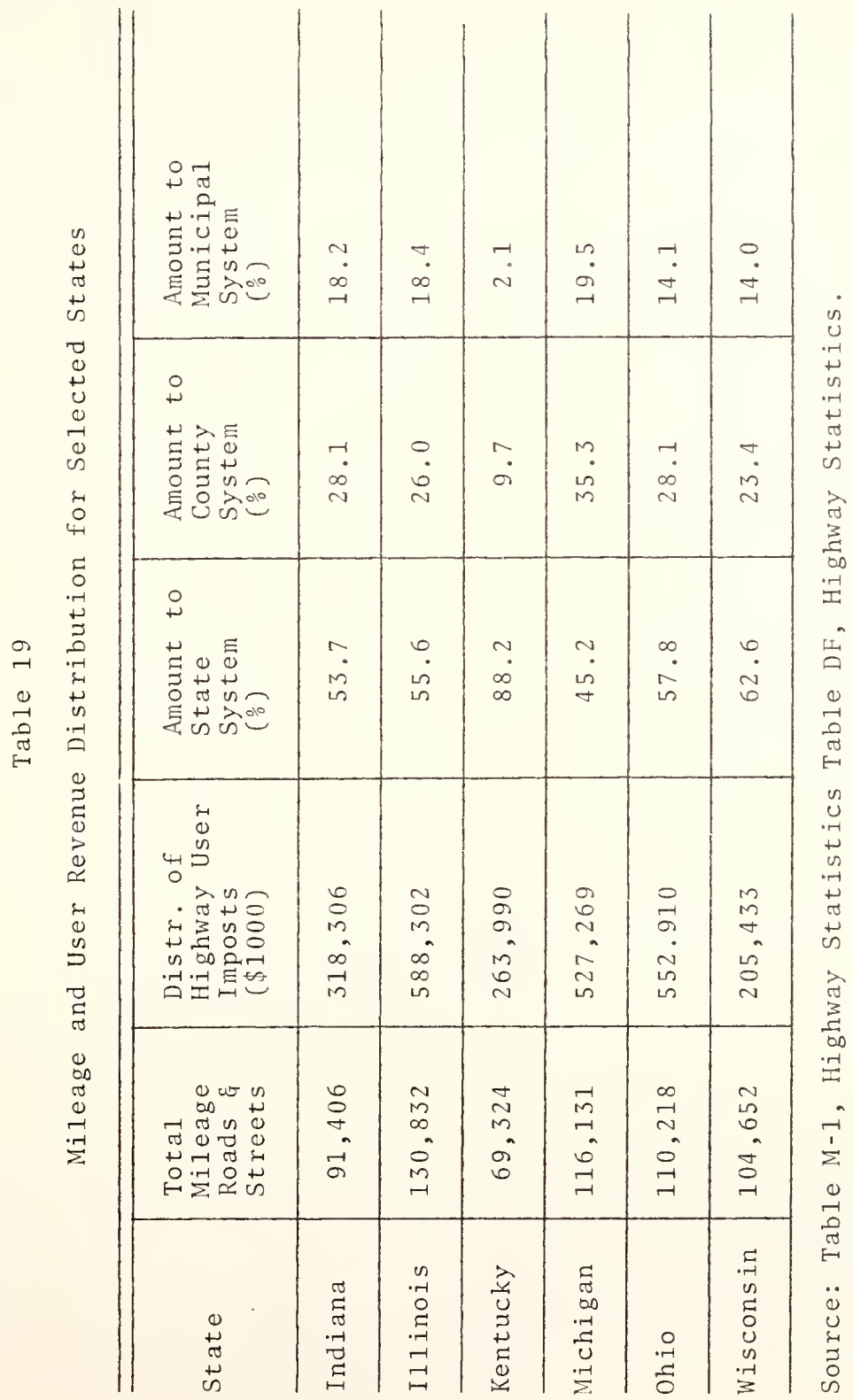




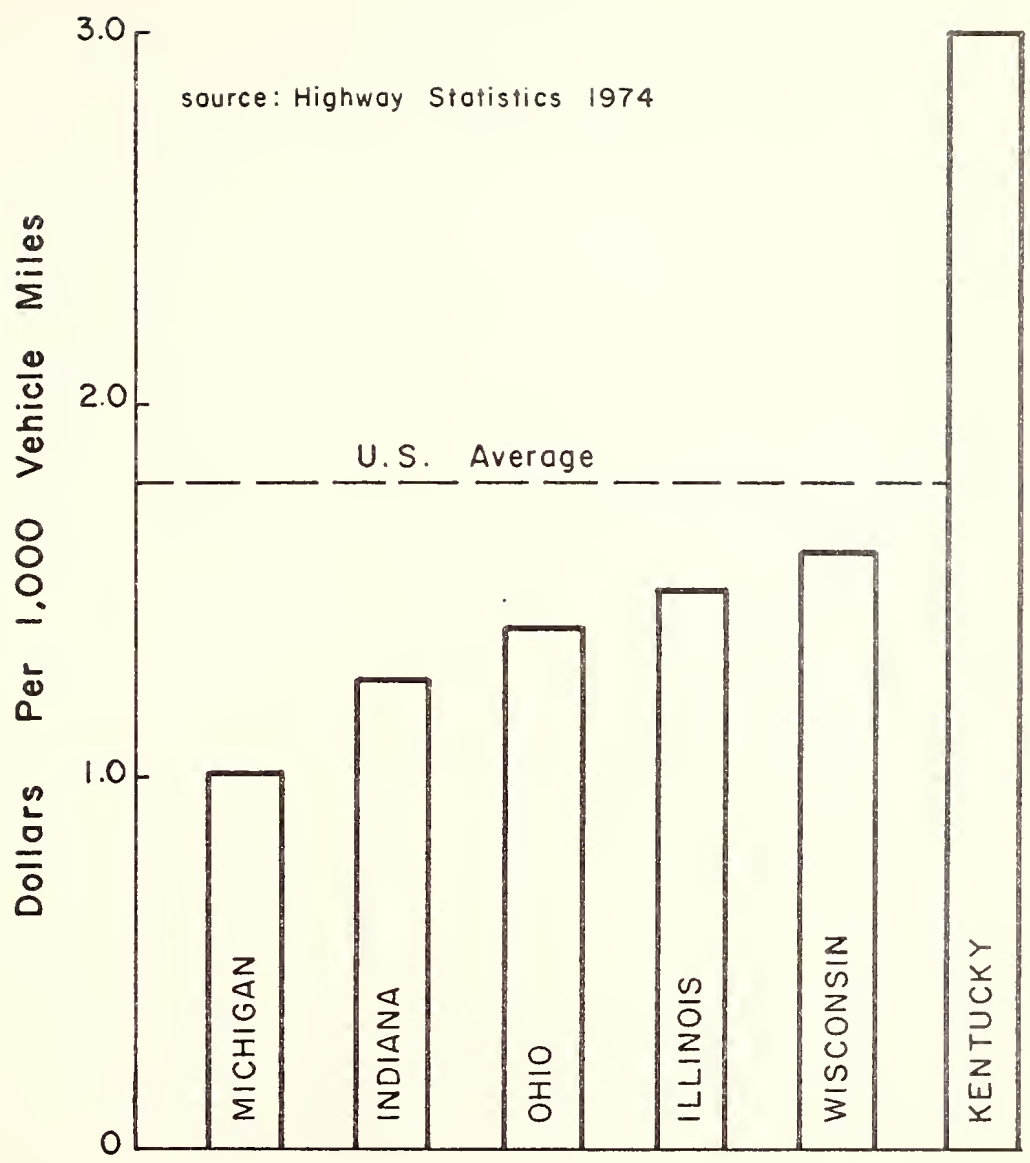

FIGURE 10.EXPENDITURES PER VEHICLE MILE OF TRAVEL FOR MAINTENANCE ON ROADS UNDER STATE JURISDICTION. 
of the Midwest states in this catagory with an average expenditure of 1.25 dollars per 1000 vehicle miles of travel. The U.S. average is 1.79 dollars per 1000 vehicle miles of travel and only Kentucky exceeds this average in the Midwest.

In summary, what all these comparisons show is that Indiana may increase its user tax fees, at least to the national averages, and possibly raise additional revenues to meet the needs for operation and maintenance of Indiana highways. 
CHAPTER $V$

AD VALOREM TAXATION

The mainstay of the highway revenue structure since the conception of highway user financing, has been the tax on fuel consumed in motor vehicles operated on public highways. It is generally felt that taxation on the basis of fuel consumption distributes the costs of providing highways in an equitable manner. The highway cost per vehicle mile of travel can be roughly measured by the amount of tax paid per gallon of fuel consumed. However, since all vehicles are not exactly the same in regard to weight and fuel efficiency, the states have adopted some supplementary taxation on heavier vehicles to compensate for these deficiencies in the motor fuel tax alone. In most cases this supplementary tax takes the form of annual taxes based on the declared gross weight of the vehicles.

Traditionally, highway user taxes are established as fixed rates rather than variable or escalating. The difficulty with fixed rate structure is that it does not self-adjust to inflationary pressures but require legislative action to change rates. Legislative action responding to inflationary pressure and needs in the 
highway sector has been slow in the past. It is felt that some self-adjusting form of taxation is needed for highway financing [49]. This type of taxation would "automatically" provide additional highway revenue as costs increased but without subjecting legislative bodies to frequent proposals for increased fuel taxation.

At the present time, eighteen states are considering increasing their fuel tax rates. Nine states are seriously considering an ad valorem tax to replace the present per gallon tax structure. This type of taxation is sometimes referred to as an escalating or sliding-scale tax and would function much like a sales tax tied to the retail price of gasoline. Unlike general funds which have the ability to fluctuate in accordance with rises and falls in the state's economy, highway user taxes are affected by more permanent conditions having long term effects. For this reason any recommendations for increased revenue should provide a long term solution rather than merely satisfying the immediate needs. The ad valorem tax is capable of accomplishing this objective. It solves the problems of periodically asking the legislature for an additional tax increase when costs reach the point where the highways cannot function without supplementary revenues. While general funds support and periodic one and two cent increases are seen as temporary solutions, the ad valorem tax provides a long term solution to highway financing. 
The workings of the ad valorem taxing scheme are easily understandable. In lieu of the present per gallon State tax on motor fuel, a sliding tax is imposed which varies in direct relationship to the retail price per gal1on. This tax is then an ad valorem tax similar in nature to the State's sales tax but it applies only to motor fuel.

This ad valorem tax can be computed every six months by the State based on the "weighted average retail sales price" of motor fuel sold within the State. The State may determine this weighted retail price by a statewide sampling and survey technique designed to reflect the average selling price, exclusive of Federal and State taxes. To provide the minimum funds needed and to prevent windfall profits, a minimum and maximum tax rate per gallon can be set (i.e. $9 \$$ and $12 \$$ ). The percentage that would be applied to the weighted average sales price can be determined according to the highway needs but subject to legislative approval. Collection of revenue will be exactly the same as with the present fuel tax.

The following illustrative example shows one procedure how an ad valorem tax could be applied. Assuming the Department of Revenue conducted a survey during the second quarter of fiscal year 1976, and found the average fuel price to be 67 cents per gallon. The tax per gallon on motor fuel for the third and fourth quarters of fiscal year 1976 could be computed in the following manner: 
$67 \$$ minus existing State tax of $8 \$$, minus existing Federal tax of $4 \phi$,

$=55 \$$ This is the average weighted price.

Assuming an ad valorem tax of $20 \%$ legislated on this weighted price,

$20 \%$ of $55 \$$ is 11 per gallon tax, that can be levied for the next two quarters of the fiscal year.

This 11 cents per gallon tax would replace the 8 cent tax and be collected from the distributors by the Department of Revenue in the same fashion as the previous 8 cent per gallon tax was collected. In the fourth quarter of fiscal year 1979, the Department of Revenue would again take a statewide sample and compute a new tax per gallon for the first six months of fiscal 1980 [50]. It should be noted that, instead of converting the ad valorem tax into cents per gallon rate, it can be collected directly as a percent sales tax.

The ad valorem tax would have the following long range advantages:

1) It would be compatible with and take advantage of methods and procedures presently utilized for the collection of fuel taxes.

2) It would provide a tax base that increases as the price per galion of fuel increases, meaning an offsetting of inflationary effects and compensat ing for reduced fuel consumption.

3) It offers maximum and minimum limits per galion thereby insuring no great loses or windfall profits.

4) It minimizes the confusion to dealer, distributor, and government by operating with as iittle change as possible to present laws, rules and regulations regarding motor fuel tax collections. 
While there are many obvious long range advantages to the ad valorem taxation policy, some disadvantages to this type of taxation are also apparent. The major disadvantages are:

1) A California State Highway Tax Study Commission had this to say about the ad valorem tax;

The proponents of an ad valorem tax see it as a solution to the escalating cost of building and maintaining streets and highways. They assume that the price of fuel will rise at least as fast as other costs, but this isn't necessarily true, because the price of oil is highly controlled, both within the United States and through actions of foreign governments.[51]

2) Revenues should increase as travel and the corresponding demands on the highway system increase. This is how the present tax structure operates. But on what conceptual basis can it be argued that fuel taxes for highways should go up simply because fuel prices go up?

3) This third disadvantage is not one of method but rather of implementation. The proposal of a percentage tax of 20 to 30 percent is embarassingly high to legislative bodies. Resistance to any such wording or indication of taxes of such magnitude would be legislatively unworkable. 
It can also be argued that the price of fuel, if used as an economic index or indicator of general price trends, can provide a valid base for highway revenues. Petroleum based products are heavily used in highway maintenance and construction and therefore highway costs are influenced to a significant extent on the price of these products. Accordingly, it appears that fuel cost gives a good indication about the cost trend in highway industry.

\section{Specific Proposa1s By Two States}

Some nine states are considering specific legislation regarding an ad valorem fuel tax. Because of this growing interest in ad valorem taxation, two specific proposals from Washington and Utah are presented in the following pages.

The Washington Proposal*

In 1975, both Houses of the Washington State Legislature passed Senate Bill Number 2158, otherwise known as the "variable fuel tax bill". This bill was designed to provide a revenue base for State and local highway programs which responds to inflationary pressures. To achieve this purpose the fuel tax would be set at 20 percent of the weighted average retail fuel price which included

* Information was obtained through correspondence with the Washington State Highway Commission. 
Federal tax but excluded State tax. A number of provisos were included in the bill which allowed deviation from the 20 percent in order to retain a reasonably stable revenue base. The provisos related to upper and lower limits as follows :

1. The tax rate could be no lower than 9 cents per gallon (this is the current rate).

2. The tax rate could be no lower than a rate which, when applied to estimated consumption for the fiscal year, would generate the same revenue as received in fiscal year 1973, plus 5\% compounded annually.

3. The tax rate could be no more than 12 cents per ga11on.

4. The tax rate could be no more than a rate which, when applied to estimated consumption for the biennium, would produce fuel tax revenues sufficient to fund biennial highway appropriations in combination with other highway revenues.

5. The tax rate prevailing in one quarter would not be lowered in the subsequent quarter unless the updated projection of revenue at the prevailing rate would exceed the appropriation limit mentioned in 4, above. (This proviso was included to minimize excessive quarterly rate fluctuations which would otherwise be 1ikely).

Although this bill had generated much support, it was vetoed by the Governor and never implemented.

The Utah Proposal

The problem of financing the Utah Department of Transportation has dramatically taken a turn for the worse in current years, and projected revenues versus needs looks even worse. For Fiscal Year 1978, Utah 
estimated expenditures will exceed revenue by 18.3 million dollars and the same comparison for 1982 indicates expenditures will exceed revenue by 32.8 million dollars. These figures include a moderate construction program and continued maintenance at its present level of service. These expenditure figures are also based on an anticipated inflation growth of 7.5 percent which they have estimated from a composite of Construction Cost Index, Consumer Price Index and the Implicit Price Deflator Index. The conditions creating this problem were seen to be the reduction of motor fuel consumption, inflation and appropriations to other state agencies.*

Although various alternatives were evaluated, it was felt that the ad valorem or sliding tax on motor fuel provides the best compensation regarding the factors of inflation and reduced fuel consumption. At the same time, only this alternative provides the magnitude of additional highway user funds needed by the Department.

The sliding or ad valorem tax on motor fuel and special fuels would replace the present 7 cents per galion tax on motor fuel in the state. This ad valorem tax would be computed every six months and would be based on the average retail sales price minus State and Federal taxes of motor fuel sold within the State.

* Taken from "Recommendation for Ad Valorem Tax", Utah Department of Transportation, Office of Policy and Systems Planning, June 8, 1976. 
The tax rate was set at 20 percent since this percentage would provide the magnitude of funds needed by the Department. This proposal is still under consideration.

The Utah proposal is very similar to the Washington proposal with the exception of a few refinements. The re-evaluation of the tax situation only two times per year is seen to be more reasonable then 4 times per year as proposed by Washington. This has the advantage of simplifying the procedure of tax calculations making ad valorem taxation that much more attractive.

While nine states are studying the implementation of the ad valorem tax for motor fuel, the Pennsylvania and Delaware legislators have just rejected escalating tax peoposals in 1975. The Pennsylvania escalating tax bill called for a 30 percent tax on the total retail fuel price and was defeated in both 1973 and 1975. Although it has not yet been recognized by the legislatures, the idea of ad valorem taxation can help in solving the highway revenue problems in Indiana and other states across the nation.

If the ad valorem fuel tax can be made legislatively acceptable, the benefits of increased highway revenues would help many states now struggling with inadequate financing. While not perfect in all aspects, this type of taxation increases highway revenues in periods of inflation within prescribed limits set by 1 aw. 


\author{
CHAPTER VI \\ PROJECTED INDIANA HIGHWAY REVENUES
}

This chapter explores the ways in which Indiana has been affected by inflation and decreased fuel consumption along with how these factors will influence forecasted revenues.

The highway user revenues were forecasted to the year 1995 on the basis of future state population, per capita personal income, vehicle miles of travel and alternate taxing assumptions. Some alternative proposals for increasing revenues were also prepared as examples of methods to increase highway funds.

\title{
Indiana Highway Needs
}

There is currently a comprehensive needs study in progress for Indiana highways. Highway needs will not be accurately known until the ongoing study is completed, but as needs will most likely rise each year, the search for methods to increase highway revenues will be of utmost importance. 


\section{State Highway Revenue Forecasting Methodology}

The forecasting of state highway revenue for the next twenty years (1975-1995) estimates the foreseeable highway user revenues available to Indiana highways. The variables which affect generated revenues, such as vehicle miles of travel, vehicles per capita and Indiana population growth, were all considered when future revenues were projected. The population forecast is the basic element to the methodology. Both the motor fuel tax revenue and vehicle registration fees were estimated from this starting point and were then summed together to obtain total highway user revenue estimates. This methodology is summarized in Figure 11 which shows the interrelationships between the different estimates and how they were combined to estimate total user revenues. Appendix $C$ contains the computer program designed for highway revenue projection in Indiana. The following pages discuss in detail the development of the forecasting proceedure.

\section{Population}

The forecast of Indiana population growth was input to both vehicle registration and vehicle miles of travel projections. To forecast the population, the Cohort Survival Method of population projection was used. This is a demographic technique which analyzes changes in the components of population change: births, deaths, and migration. This method uses separate projections for births, deaths and net 


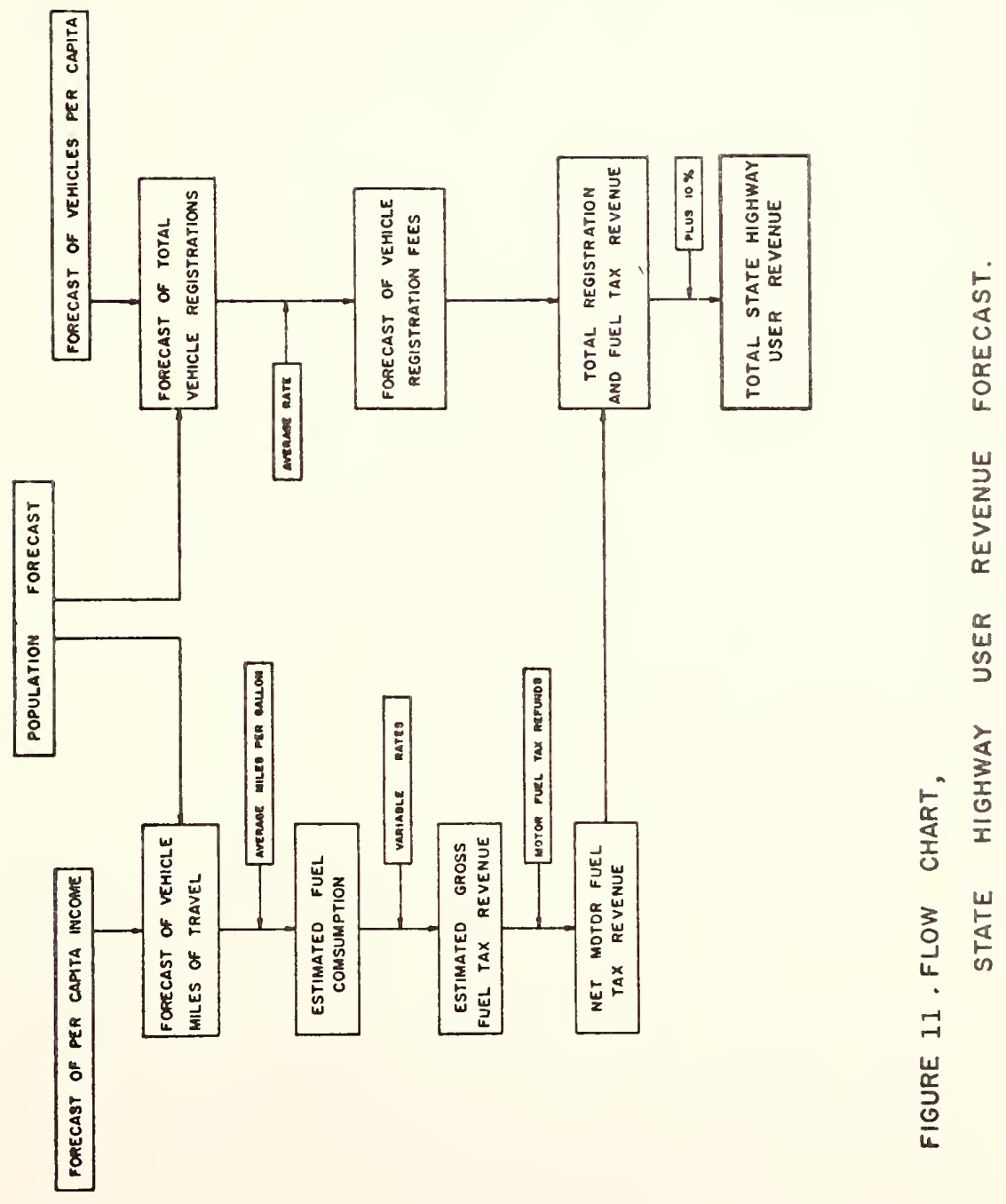


migration to derive the future population. The projections are made by age-sex groupings. The actual five year age-sex groups were taken from the 1970 U.S. Census.

Three main projection series are presented in this report. All three series start with an estimated July 1 , 1970 population and assume a slight reduction in future mortality. A five year net migration of 32,500 persons into Indiana was estimated from past historical trends and was used as input to the population projections. These three population series differ only in their assumptions concerning future fertility rates. The ultimate levels of completed cohort fertility (average number of lifetime births per woman), taken from Bureau of the Census were as follows [52]:

$$
\begin{aligned}
& \text { Series I }-2.7 \\
& \text { Series II }-2.1 \\
& \text { Series III }-1.7
\end{aligned}
$$

Alternative assumptions were made about the course of fertility because of the difficulty of ascertaining the number of future births, even in the short run. These assumptions were believed to provide a reasonable range, as no one series is likely to depict the future course of fertility for an extended period. Social, economic, and other factors which affect fertility are neither fully understood nor easily predicted. 
The Cohort Survival Method produced the population projections in Table 21 based on births, deaths, and net migration in Indiana.

Table 20

Indiana Population Projections

\begin{tabular}{l|c|c|c}
\hline & \multicolumn{3}{|c}{ Population (millions) } \\
\cline { 2 - 4 } Year & $\begin{array}{c}\text { High } \\
\text { Series I }\end{array}$ & Medium & Low \\
\hline 1980 & 5.737 & 5.626 & 5.537 \\
\hline 1985 & 6.134 & 5.901 & 5.723 \\
\hline 1990 & 6.547 & 6.171 & 5.896 \\
\hline 1995 & 6.904 & 6.388 & 6.019 \\
\hline
\end{tabular}

Figure 12 shows a graphical comparison of the three series with series I and II projecting the high and low populations respectively. The Bureau of Census states that ideally Series II could be described as "most likely" or "appearing to be a reasonable choice" [53]. Series II assumes an ultimate cohort fertility rate at the replacement figure of 2.1. The projections give a range of approximately a million persons by 1995 with a Series II projection of 6.388 million population. 

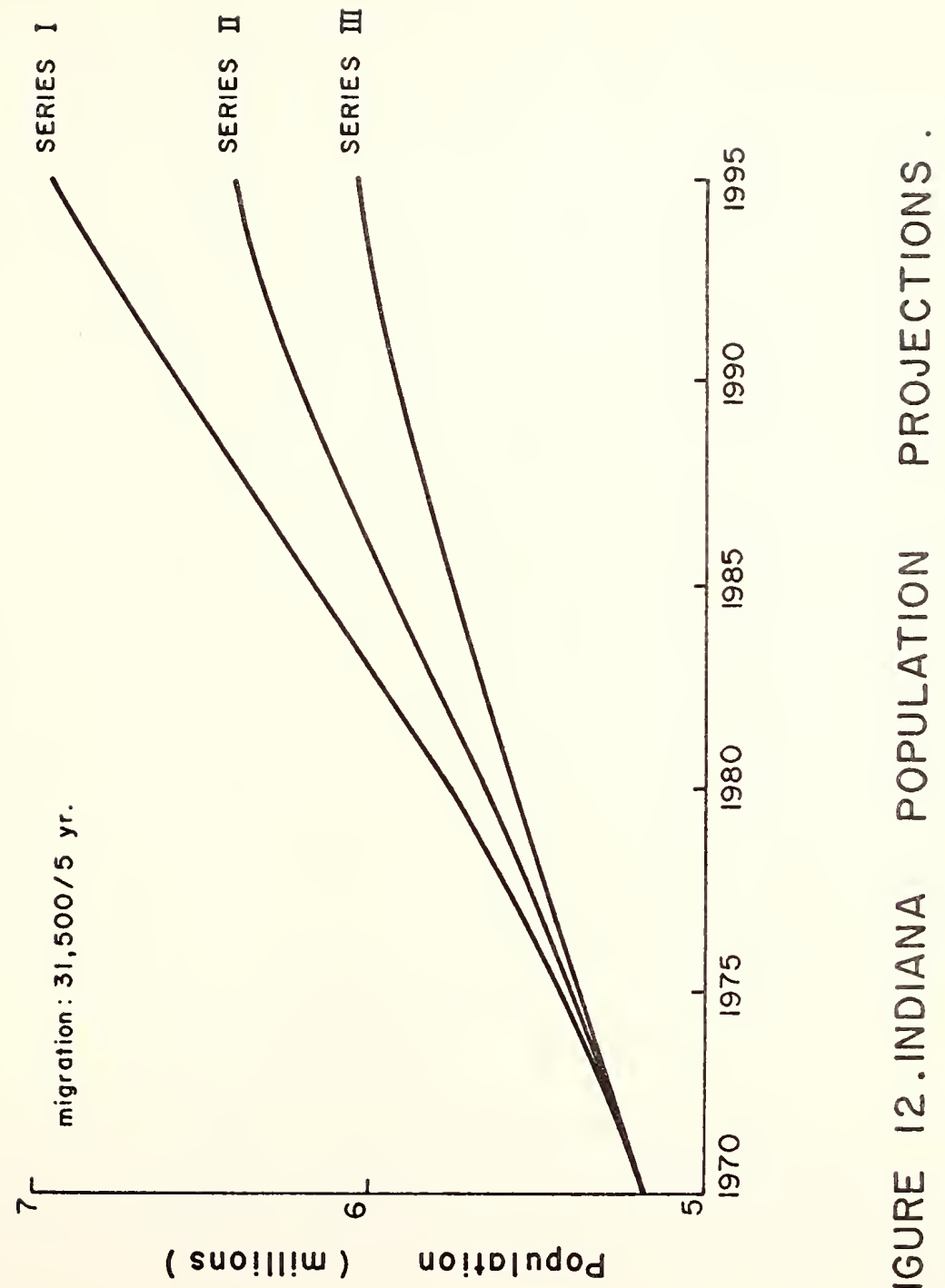

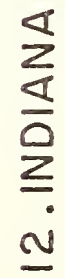

崖 


\section{Vehicles Per Capita}

The second piece of information needed to project motor vehicle registration is the number of vehicles per capita. Since 1948 the number of vehicles per capita in Indiana has been steadily rising at an average rate of 10 percent per year. However, this trend is not expected to continue. Bottiny [54] and others studying vehicle ownership and vehicle saturation trends, indicate a stabilization of vehicles per capita as saturation approaches. This was taken into account in the projection of vehicles per capita and a limiting value of .750 was chosen on the basis of past research done in this field [55]. Figure 13 shows a power curve fit to existing data on vehicles per capita with a limiting value of .750 for vehicles per capita by 1995 . The equation developed to predict vehicles per capita is given below:

Where

$$
Y=.75-.00459(95-X)^{1.18}
$$

$$
\begin{aligned}
& Y=\text { projected vehicles per capita for a } \\
& \text { desired year up to } 1995 \text {. } \\
& X=\begin{array}{l}
\text { the last two digits of the desired } \\
\text { year }
\end{array}
\end{aligned}
$$

Table 22 gives the projected ratios of vehicles per capita to be used as input to vehicle registration projections for each five years. 


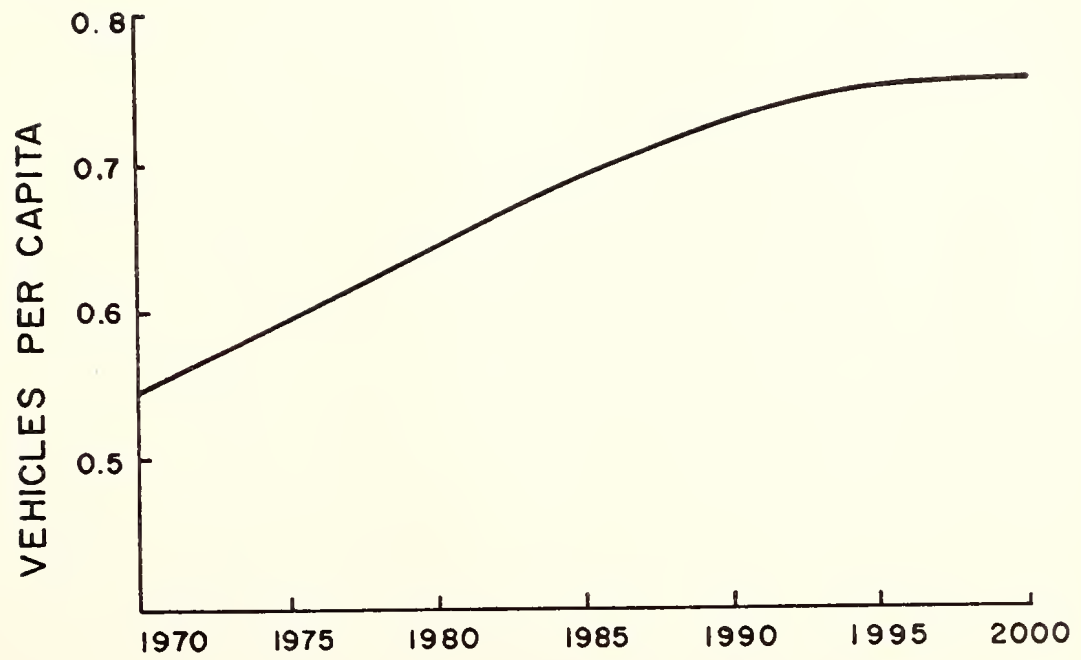

FIGURE 13. PROJECTED VEHICLES PER CAPITA 
Table 21

Projection of Indiana Vehicles Per Capita, 1980-1995

\begin{tabular}{l|c}
\hline Year & Projected Vehicles Per Capita \\
\hline 1980 & .638 \\
\hline 1985 & .681 \\
\hline 1990 & .719 \\
\hline 1995 & .750 \\
\hline
\end{tabular}

\section{Vehicle Miles of Travel}

Vehicle miles of travel in Indiana determines the fuel consumption in the state. From the projected vehicle miles of travel the amount of motor fuel tax revenue was estimated on the basis of certain assumptions regarding population and per capita income. A regression equation was developed to predict the vehicle miles of travel and the best equation obtained is shown below:

Where:

$$
Y=-30.494+.008299 X_{1}+\left(.0034776 X_{2}\right)
$$

$$
\begin{aligned}
Y= & \text { statewide vehicle miles of travel } \\
X_{1}= & \text { projected population } \\
X_{2}= & \text { Indiana per capita income in } \\
& 1975 \text { dollars. }
\end{aligned}
$$


The $\mathrm{R}^{2}$ value for this regression was .96. Population and per capita income were found to be the most significant variables for estimating future vehicle miles of travel. Population inputs were forecasted by the Cohort Survival Method and per capita income was projected by a regression equation developed from historical data. Indiana per capita income has been rising steadily since 1954 and averages 10 percent increase per year. The regression equation developed for per capita income was:

$$
\begin{aligned}
& Y=(-200398.15+104.43 X) \\
& \text { Where: } \quad(F=238.87) \\
& Y=\text { per capita income (in } 1975 \text { dol1ars) } \\
& X=\text { the desired year }
\end{aligned}
$$

The $\mathrm{R}^{2}$ value for this regression was.91. Table 23 presents the adjusted per capita income projections for the twenty year period. The per capita income in 1975 dollars is expected to rise from 6,364 dollars in 1980 to 7,931 dollars in 1995 . 
Table 22

Adjusted Per Capita Income Projections

\begin{tabular}{l|cc}
\hline Year & Adjusted Per Capita Income (1975 doliars) \\
\hline 1975 & $\$ 5847$ & (present income) \\
\hline 1980 & 6364 \\
\hline 1985 & 6886 \\
\hline 1990 & 7409 \\
\hline 1995 & 7931 \\
\hline
\end{tabular}

Given the projected values of population and per capita income, vehicle miles of travel is estimated for the three population alternatives. The projected vehicle miles of travel for high, medium and low population alternatives are shown in Figure 14. These projections vary from a high of 54.5 billion miles to a low of 47.88 billion miles with a medium projection of 50.12 billion vehicle miles of travel.

\section{Estimated State Highway User Revenue}

As previously illustrated, the two major sources of highway user revenue, registration fees and motor fuel tax, must be forecast to obtain estimates of the total highway user revenue in Indiana. 


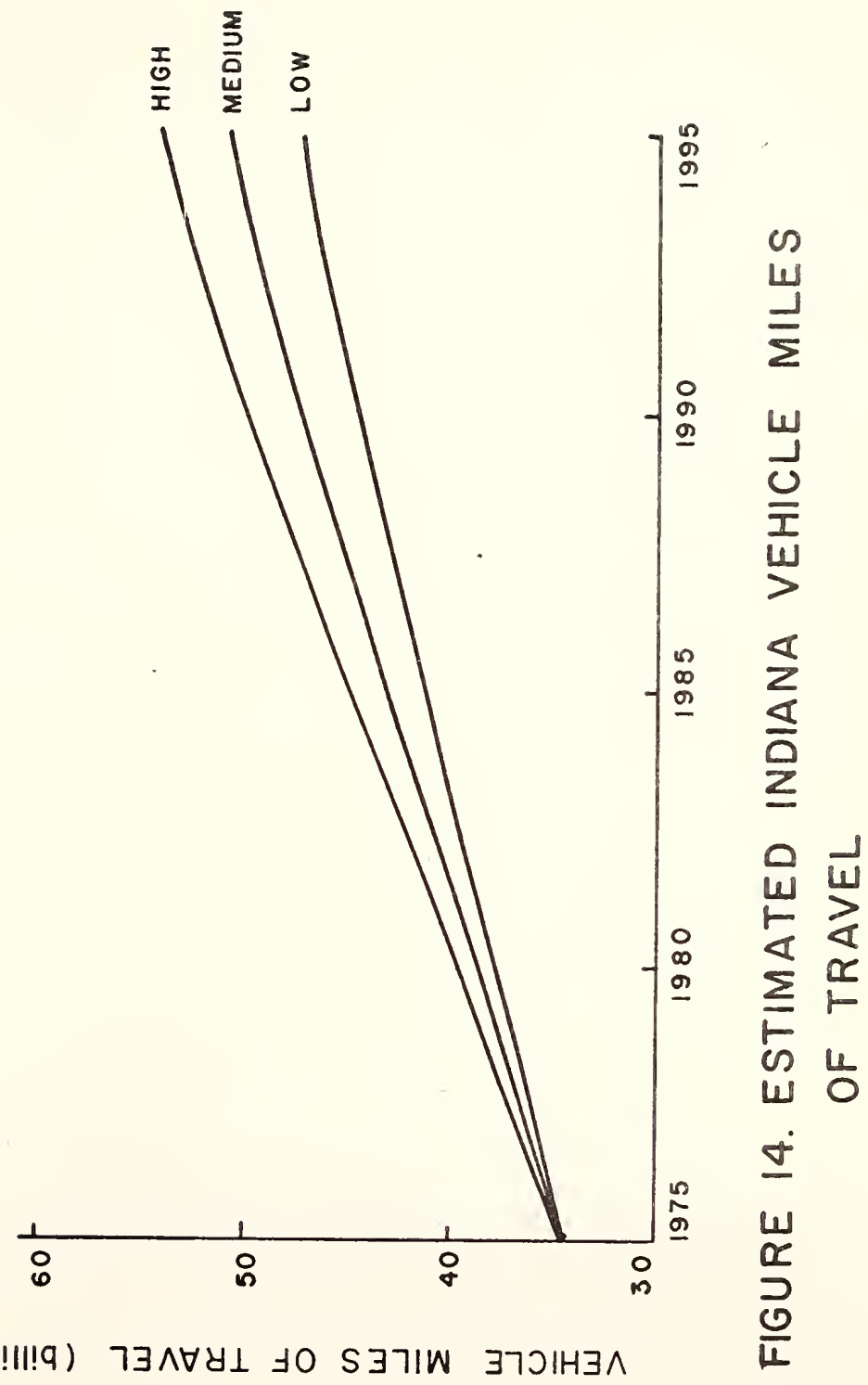


Motor Vehicle Registration Fees

The total number of motor vehicle registrations in Indiana is expected to increase to almost 1.6 million vehicles by 1995. Consequently, motor vehicle registration fees will increase by almost 30 million dollars assuming no change in the present fee structure. Table 23 shows the five year motor vehicle registrations and revenues assuming the present fee structure remains unchanged. Figure 15 illustrates the relationship between the high, low and medium assumptions concerning vehicle registrations derived from population and vehicle per capita estimates. By converting these registrations into total registration fees paid, the range of possible future revenues is developed as shown in Figure 16.

\section{Motor Fuel Tax Revenue}

Vehicle miles of travel in Indiana were estimated to increase to an estimated 50 billion vehicle miles by 1995 . A summary of vehicle miles of travel under varying assumptions are shown by five year intervals in Table 24.

The net motor fuel tax revenue was easily projected knowing the vehicle miles of travel, average miles per gallon consumed per vehicle and estimated fuel tax refunds. 


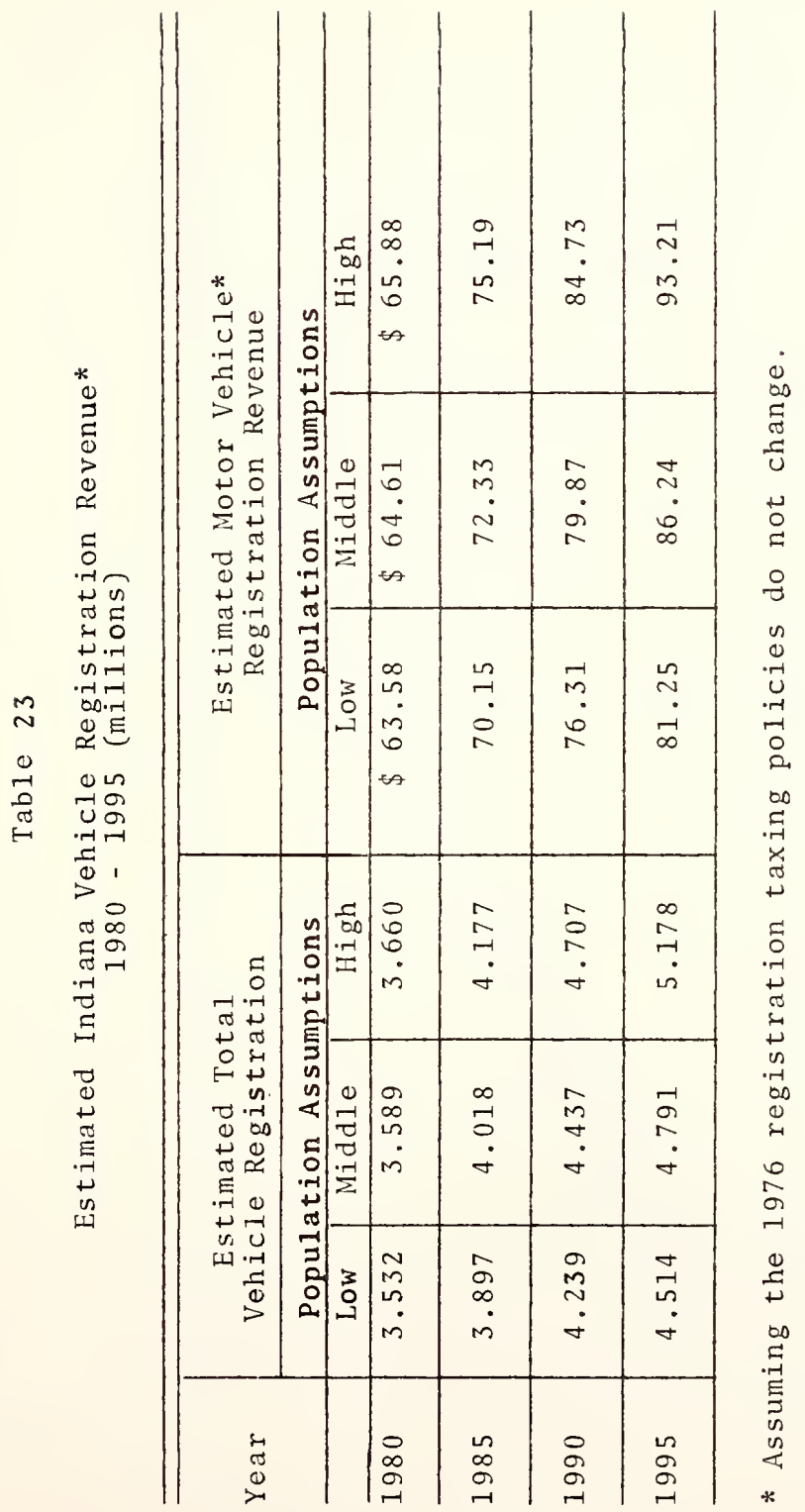




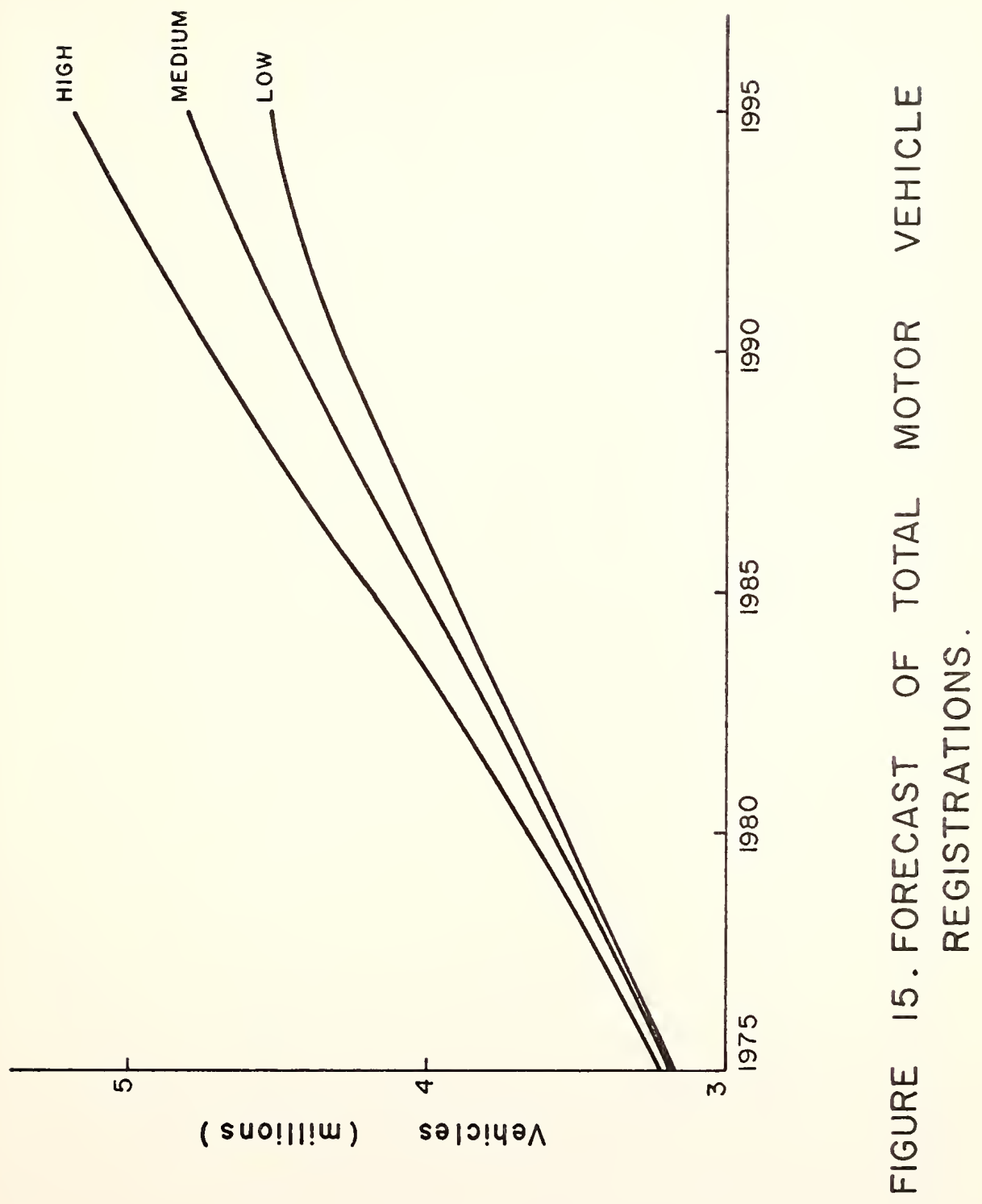




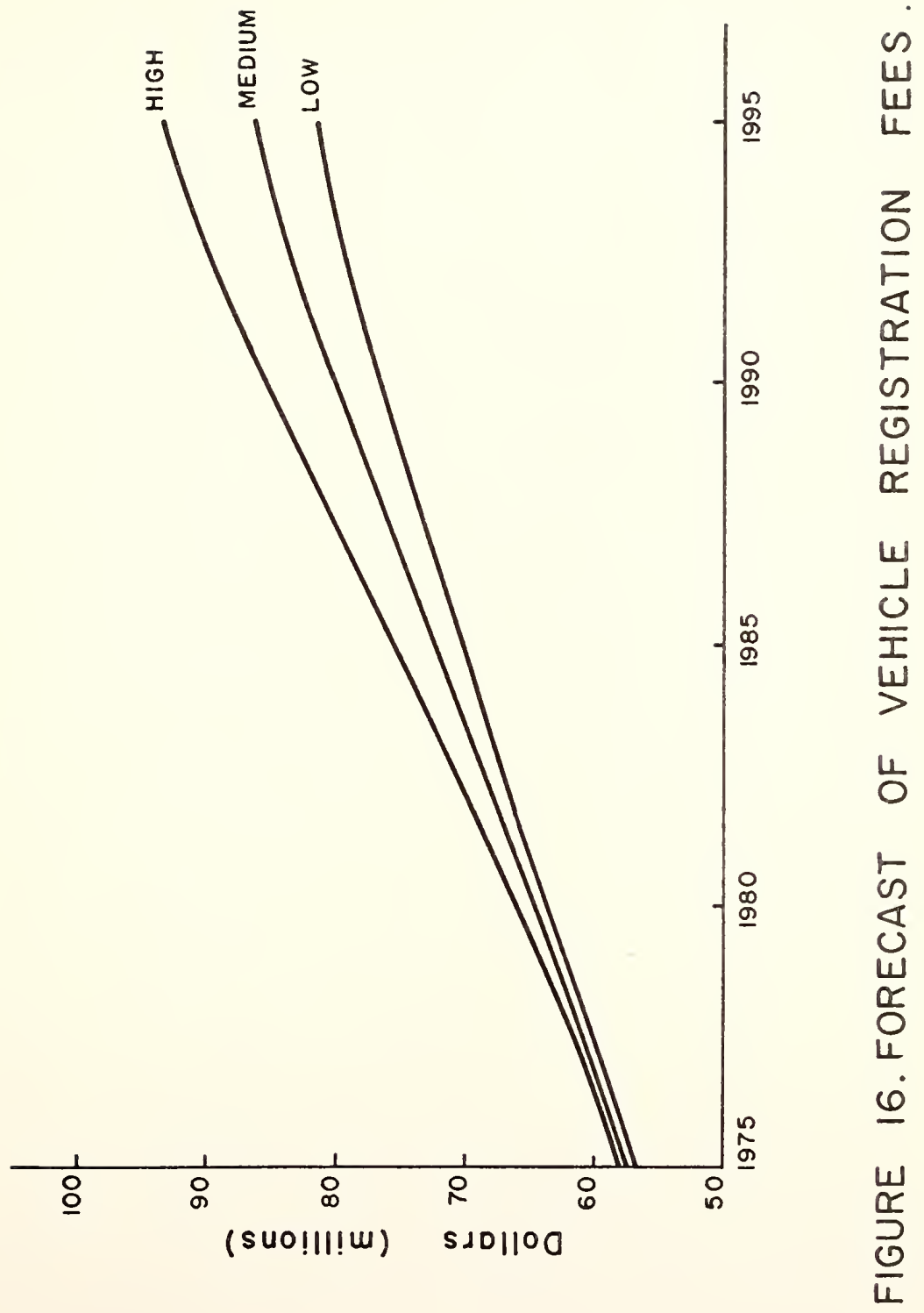


Table 24

Estimated Indiana Vehicle Miles of Travel 1980 - 1995 (billions of miles)

\begin{tabular}{l|r|r|r}
\hline \multirow{2}{*}{ Year } & \multicolumn{3}{|c}{ Vehicle Miles of Travel } \\
\cline { 2 - 4 } & High & Medium & Low \\
\hline 1980 & 39.4 & 38.4 & 37.8 \\
\hline 1985 & 44.7 & 42.5 & 41.1 \\
\hline 1990 & 49.8 & 46.7 & 44.3 \\
\hline 1995 & 54.5 & 50.1 & 47.9 \\
\hline
\end{tabular}

The estimation of the change in average miles per gallon was difficult to estimate for future years. The long run trend has been toward less miles per gallon and currently stands at 12.15 miles per gallon as an average for all vehicle types. However, this trend may be reversed by current emphasis on fuel economy in the production of new automobiles. The rates used in the motor fuel revenue forecasts are shown in Table 25. Scenario I which is the low alternative assumed $12.15 \mathrm{~m} \cdot \mathrm{p} \cdot \mathrm{g}$. for the twenty year period. The medium and high alternatives assumed an in creasing fleet mix m.p.g. to an ultimate 1995 limit of 15 and 20 miles per gallon respectively. Figure 17 shows the relationships of these three assumptions over the twenty period. 


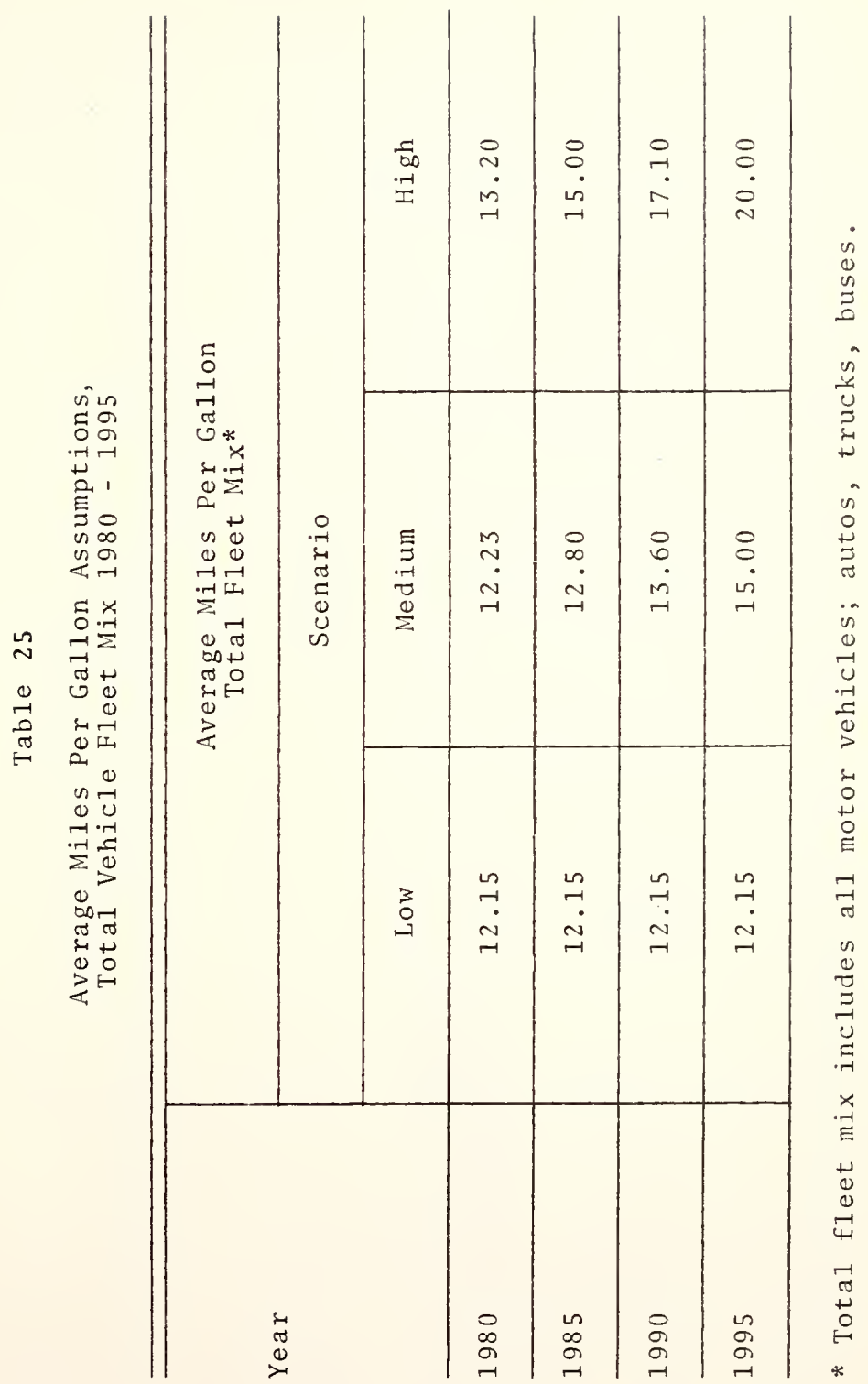




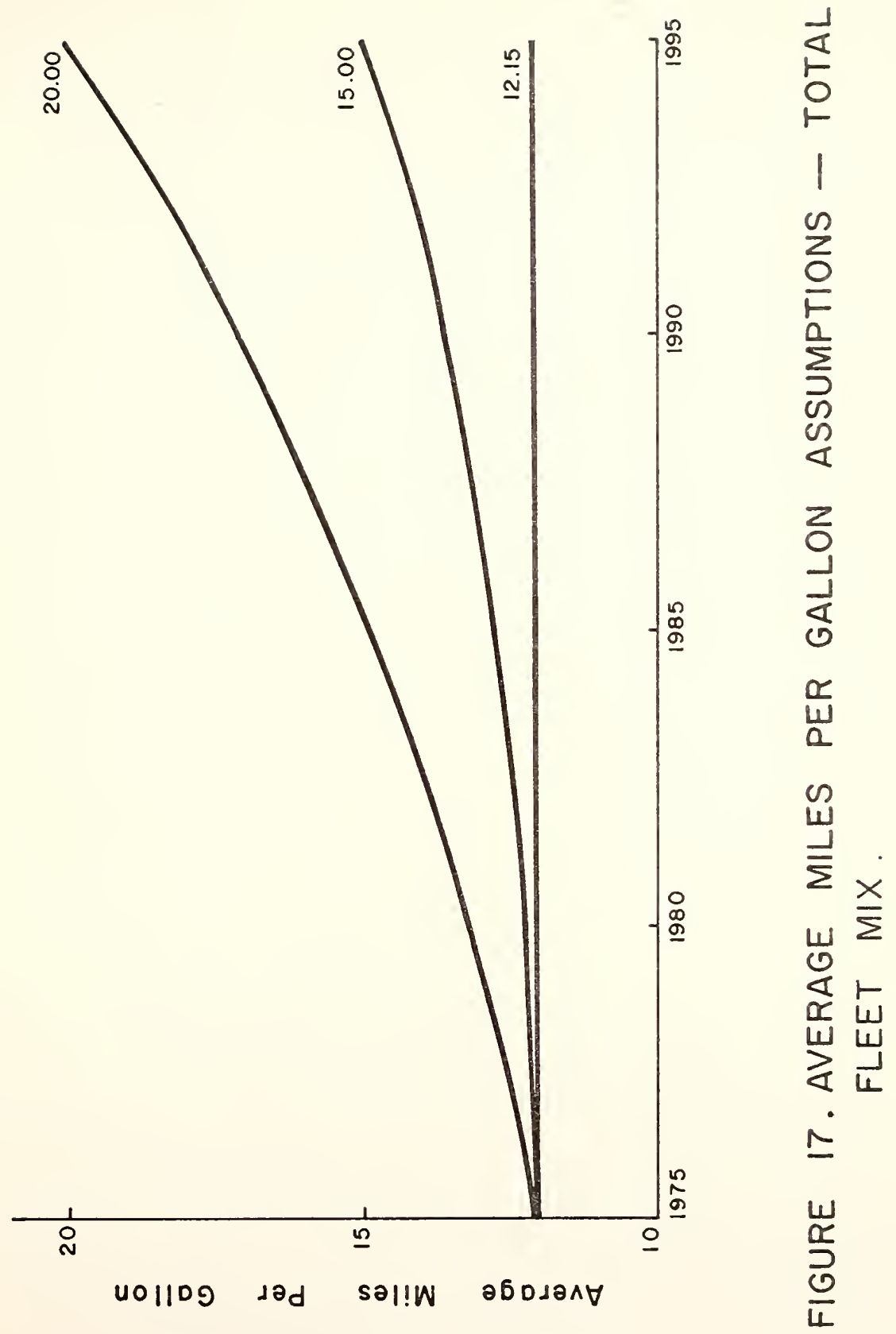


Once the miles per gallon estimates were established and the vehicle miles of travel projected the motor fuel revenues for each alternative were calculated. The estimated vehicle miles of travel multiplied by a fuel consumption alternative yielded the State total gallons of motor fuel consumed. The total gallonage of fuel was then multiplied by an assumed fuel tax rate to give estimated gross fuel tax revenues. The net fuel tax revenues were computed by subtraction of motor fuel refunds (evaporation, spillage and non-highway use tax compensation) from the gross fuel tax revenues. These refunds were estimated as 3 percent of the gross receipts arrived at from analysis of past data. The motor fuel tax revenues were estimated for alternative assumptions in the following manner:

$$
\text { if } Y=\text { net fuel tax revenues }
$$

Then: $\quad Y=V_{1} C_{1} R_{1}-.03\left(V_{1} C_{1} R_{1}\right)$

Where: $\quad V_{1}=$ estimated vehicle miles of travel

$\mathrm{C}_{1}=$ fuel consumption a1ternative

$R_{1}=$ assumed tax rate

Table 26 contains calculated motor fuel tax revenues for one combination of assumptions which yielded a 1995 fiscal motor fuel tax revenue of 306 million dollars. This was calculated on the basis of low vehicle miles of travel, an 8 cent per gallon fuel tax, and the exisiting 12.15 miles per gallon fuel consumption. This example shows only one of over one-hundred possible combinations of future conditions which were projected. 


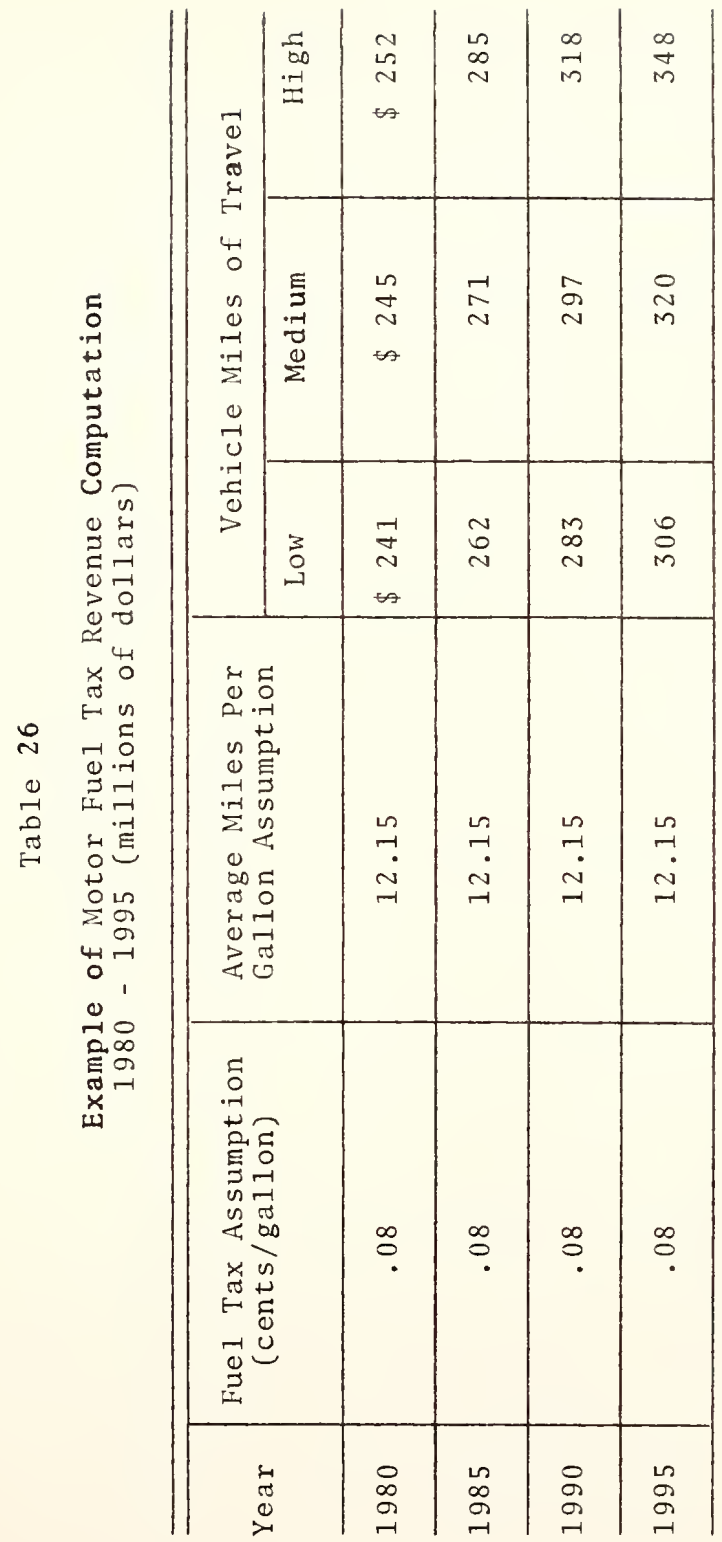


Total Highway User Revenues

Motor vehicle registration fees and motor fuel tax revenues have historically comprised about 90 percent of the total Indiana highway user revenues. This represents an average percentage, as the actual percentages change slightly each year. For projection purposes, registration and fuel tax revenues were estimated as 90 percent of total revenues, which is close to the national average of 89.6 percent.

The methodology used, in this study, to obtain the total State highway user revenues is to sum the motor vehicle registration fees and motor fuel taxes developed in the previous sections and add 10 percent for miscellaneous highway user revenues. This extra 10 percent represents revenues from motor fuel and motor vehicle related taxes such as distributor licenses and vehicle transfer fees and also includes motor carrier fees and other miscellaneous revenues. Table 27 is an example of how the total highway user revenue can vary with different assumptions of vehicle miles of travel. In this Table, as before, the fuel tax is eight cents, the miles per gallon are estimated at 12.15 and the three vehicle miles of travel assumptions are 1isted. Again, many combinations of factors 


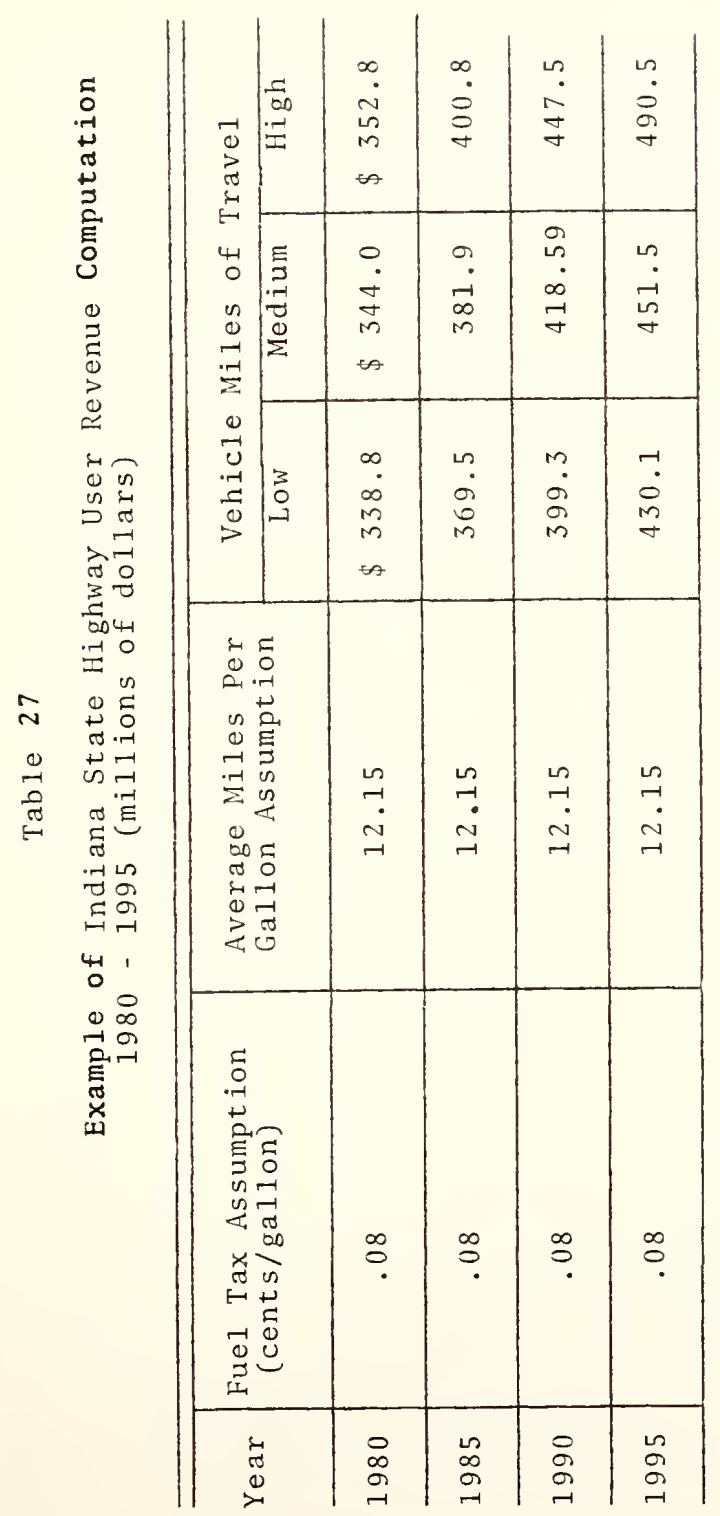


are possible, but this example varies from 430 million dollars to 490 million dollars in 1995 using 1 ow and high vehicle miles of travel estimates respectively.

\section{Alternatives for Increasing User Revenues}

The majority of the states across the nation are in agreement in one aspect of highway financing: increased costs and decreasing revenues make it necessary to economize, and increase efficiency and productivity in every aspect of highway planning, design, operation and maintenance. No matter what decisions are reached concerning additional revenues for highways in Indiana in the coming years, it will be necessary for the state to carefully budget its resources and attempt higher productivity and effectiveness. At the same time it may be necessary to review and modify the financing policy related to State highways. In this regard several alternatives can be evaluated: (A) reproportion the existing highway revenue sources to conform with national averages, (B) utilize an ad valorem or flat per gallon tax to increase motor fuel revenues and (C) reproportion the existing highway user revenues, and increase the fuel tax revenues by an ad valorem tax.

In the following pages each of the alternatives are discussed in detail with sample computations for 1976. These computations show the additional revenue generated by each example if it were in force during 1976. 


\section{Example A}

Example A adjusts the components of highway user revenue, exclusive of motor fuel tax, to conform with the national averages. The motor fuel tax is retained at the present 8 cents per gallon and reproportioning is as shown below [56].

1976

\begin{tabular}{lrrr} 
& \multicolumn{2}{c}{ INDIANA } & U.S. \\
& $(\$ 1000)$ & Pct. & Pct. \\
Motor Fuel Gallonage Tax & $\$ 249,285$ & $72.2 \%$ & $61.8 \%$ \\
Motor Fuel Other Receipts & 2,134 & 0.6 & 0.5 \\
$\begin{array}{l}(8 \$ \text { Tax }) \\
\text { Motor Vehicle Regis. Fees }\end{array}$ & 70,722 & 20.4 & 27.8 \\
Other Motor Vehicle Fees & 14,885 & 4.3 & 6.3 \\
Motor Carrier Taxes & 1,435 & 0.4 & 1.6 \\
Miscellaneous Fees & 6,900 & 2.0 & 2.0 \\
TOTALS & $\$ 345,361$ & $100 \%$ & $100 \%$
\end{tabular}

Reproportioning Indiana's revenue for motor vehicle registration fees to the U.S. average of 27.8 percent the following figure is obtained:

Increase in amount of revenue for motor vehicle registration fees equals, $((249,285 / .618) * .278-70,722) * 1000=41.416 \mathrm{millions}$ It should be noted that the percentages of other sources of revenue also change accordingly. For example, the motor fuel gallonage receipts are proportioned to 61.8 percent of the total revenues. 
If registration fees are to yield the additional 41.416 million dollars as shown, fees will have to be raised 58.6 percent. As truck registration fees in Indiana are low when compared with other midwestern states, it would be conceivable that trucks be assigned a greater portion of the cost burden than automobiles. Further study of this cost allocation may be needed if motor vehicle fees are to be increased.

The catagory of "Other Motor Vehicle Fees" includes operators and chauffers permit fees, certificate of title fees and other miscellaneous fees. Reproportioning Indiana's revenue for this item to the U.S. average of 6.3 percent results in a needed increase of 10.528 million dollars. This means a 70.7 percent increase is needed in the present fee schedule. As for example, the basic operator's license fee would be increased from the present 5 dollars (for 4 years) to 8.50 do11ars.

If motor carrier tax revenue were reproportioned to the U.S. average of 1.6 percent they would need to contribute 6.454 million dollars additionally. To obtain this increase fees should be raised 450 percent. 


\section{Example B}

Example $B$ assumes a change in the fuel tax by either a 1 cent per gallon increase or an ad valorem tax of 20 percent placed on motor fuel. The ad valorem tax would replace any existing state fuel tax. The rate of 20 percent ad valorem tax is used as an example only.

INDIANA

U.S.

Example $B \cdot 1$

$(\$ 1000)$

Pct .

Pct.

Motor Fuel Gallonage Tax

$\begin{aligned} & (8 \notin \text { tax }) \\ + & (1 \notin \text { tax })\end{aligned}$

Wotor Fuel Other Receipts

$(8 \notin$ tax $)$
$+(1 \notin$ tax $)$

$\$ 249,285$

$72.2 \%$

$61.8 \%$

31,161

2,134

0.6

0.5

Motor Vehicle Regis. Fees

267

other Motor Vehicle Fees

70,722

20.4

27.8

Motor Carrier Taxes

14,885

4.3

6.3

1,435

0.4

1.6

Miscellaneous Fees

6,900

2.0

2.0

TOTALS

$(9 \notin \operatorname{tax})$

376,789

$100 \%$

$100 \%$

IND I ANA

U.S.

\section{Example $\mathrm{B}-2$}

$(\$ 1000)$

Pct .

Pct.

Motor Fuel Ad Valorem Tax

$\$ 280,446$

$74.4 \%$

61.8

(In 1 ieu of existing Tax)

(20\% of [retail price $-4 \$$ Fed. Tax])

Motor Fuel Other Receipts

4,101

0.6

0.5

Motor Vehicle Regis. Fees

70,722

18.8

27.8

other Motor Vehicle Fees

14,885

4.0

6.3

Motor Carrier Taxes

1,435

0.4

1.6

Miscellaneous Fees

6,900

TOTAL (20\% Ad Valorem Tax)

376,789

1.8

2.0

$100 \%$

$100 \%$ 
As shown in the preceding figures, the 20 percent ad valorem tax on motor fuel translates into an equivalent one cent per gallon increase. llowever, the advantage of the ad valorem tax resides in its ability to self-adjust to inflationary trends while the flat per gallon tax often takes much time and effort to effect legislatively.

\section{Example C}

This example combines an ad valorem fuel tax with reproportioning other user revenues to compare with national averages.

$$
\text { INDIANA U.S. }
$$

$\mathrm{P} 1$ an $\mathrm{C}$

Motor Fuel Gallonage $\mathrm{Tax}$ (20\% Ad Valorem Tax)

Motor Fuel Other Receipts (20\% Ad Valorem Tax)

Motor Vehicle Regis. Fees

Other Motor Vehicle Fees

Motor Carrier Taxes

Miscellaneous Fees

Total (20\% Ad Valorem Tax)
$(\$ 1000)$

$\$ 280,446$

4,101

70,722

14,885

1,435

6,900

376,789
Pct .

$74.4 \%$

Pct.

$61.8 \%$

Reproportioning Indiana's revenue for motor vehicle resistration fees to the U.S. average of 27.8 percent the following figure is obtained:

Increase in amount of revenue for motor vehicle registration fees equals,

$((280,446 / .618) * .278-70,722) * 1000=55.44$ millions

It should be noted that the percentages of other sources of revenue also change accordingly. 
If registration fees are to yield the additional 55.44 million dollars as calculated, fees would have to be raised 78.4 percent. As stated in example $\mathrm{A}$, the distribution of cost between automobiles and trucks needs further study. Evidence suggests however, that the current truck registration fees are conspicuously low compared to other states.

As before, "Other Motor Vehicle Fees" (operators and chauffers permit fees, etc.) would be reproportioned to U.S. averages. To do this an additional 13.70 million dollars would be needed which means a 92.1 percent increase in fees. For example, the basic operator's license fee would be increased from the present 5 dollars (for 4 years) to 9.60 dollars. Motor carrier fees would need to contribute an additional 5.826 million dollars meaning a 406 percent increase in fees.

The implications of these examples for Indiana highways are examined in the following chapter with estimated additiona1 revenues for each alternative from 1980-1995. 
CHAPTER VII

SUMMARY AND EVALUATION

Highway travel will continue to be the dominant mode of transportation in the United States for the next twenty years. Indiana's highway system will experience increasing demands by motor vehicles as both the number of automobiles and miles of travel are estimated to increase. To meet these demands on the system, those involved with the financing and taxation policies related to Indiana highways, must actively pursue ways to raise additional highway revenues. Problems of double-digit inflation, decreasing fuel consumption, increased emphasis on alternate transit modes, and a backlog of existing highway needs, will all cause serious revenue and cash-flow problems for highways. Many states currently need large general fund support to help match Federal-Aid funds for highway construction. While this may provide adequate short-run revenues, it is clear that legislative priorities will demand that these general funds be channeled to other governmental functions. Clearly, a more permanent solution must be sought.

One of the possible long-run solutions to inadequate highway revenues caused by cost increases and high 
inflation can be ad valorem motor fuel tax. This type of tax, functioning much like a general sales tax, has the ability to keep pace with rising highway costs as revenues increase with gasoline prices.

While the flat per gallon tax has traditionally been the mainstay for state fuel taxation, the inability of this type of tax to keep pace with rapid inflation has caused much concern. In this connection the following facts may be considered:

(1) In 1969 , the 8 cent per gallon fuel tax amounted to 23 percent of the nominal pump price of .3480 cents per gallon.*

(2) Assuming fuel consumption and vehicle miles of travel continue at the same rate as today, this same 8 cents per gallon will produce 348 million dollars in 1995.

(3) If an ad valorem tax of only 20 percent [see (1) above] were placed on motor fuel, it would produce 740 million dollars assuming retail fuel prices rise at 3 percent per year.

This example illustrates the powerful application of an ad valorem tax in situations where any inflation is thought to adversely affect future revenues.

Concluding this research the three examples for increasing highway user revenues previously introduced are summarized, with recommendations for future legislation to adequately support Indiana's highways.

* Figure taken from Interagency Task Force on Motor Vehicle Goals Beyond 1980, Marketing and Mobility, March 1976, Table 2-36. U.S. Department of Transportation. 


\section{Summary of Example A}

Example A assumes retention of the present 8 cents per gallon fuel tax with the remaining components of highway user revenue adjusted to the same proportion as the U.S. averages. Registration fees are increased from 20.4 percent of total highway user taxes to the national average of 27.8 percent. Motor Carrier fees are adjusted from 0.4 percent to Indiana's total highway user taxes to the national 1.6 percent and Motor Vehicle Other fees are adjusted from 4.3 to 6.3 percent. Table 28 summarizes the increases that example A proposes. Table 29 shows the estimated additional revenues that would be generated by implementation of example $A$ and the other two examples. It should be noted the 1980 figures are slightly below the 1976 figures. This is due to the long-term projection of vehicle miles of travel versus the short-term fluctuations Indiana is now experiencing. However, the projected vehicle miles of travel is deemed reasonable for the twenty year period. Example A provides an additional 58.40 million dollars if immediately implemented, and an additional 74.3 million dollars by 1995. In calculating these figures it was assumed that fuel consumption would remain at the current 12.15 miles per gallon, and vehicle miles of travel would increase according to the medium projection (see Table 24). 


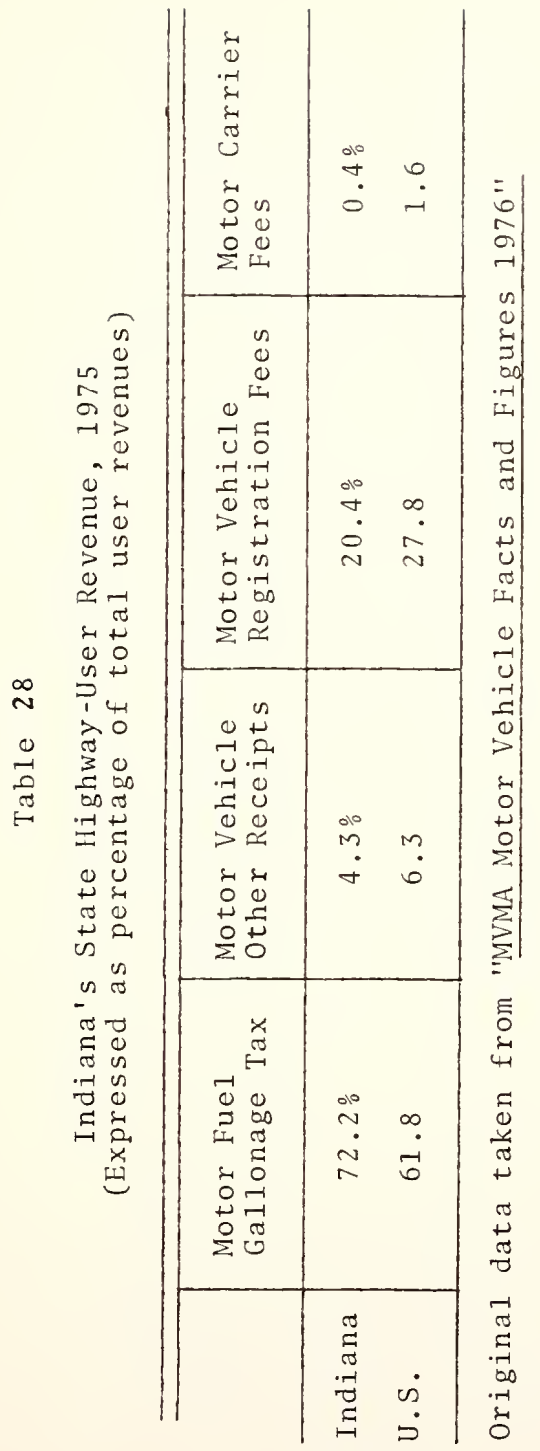




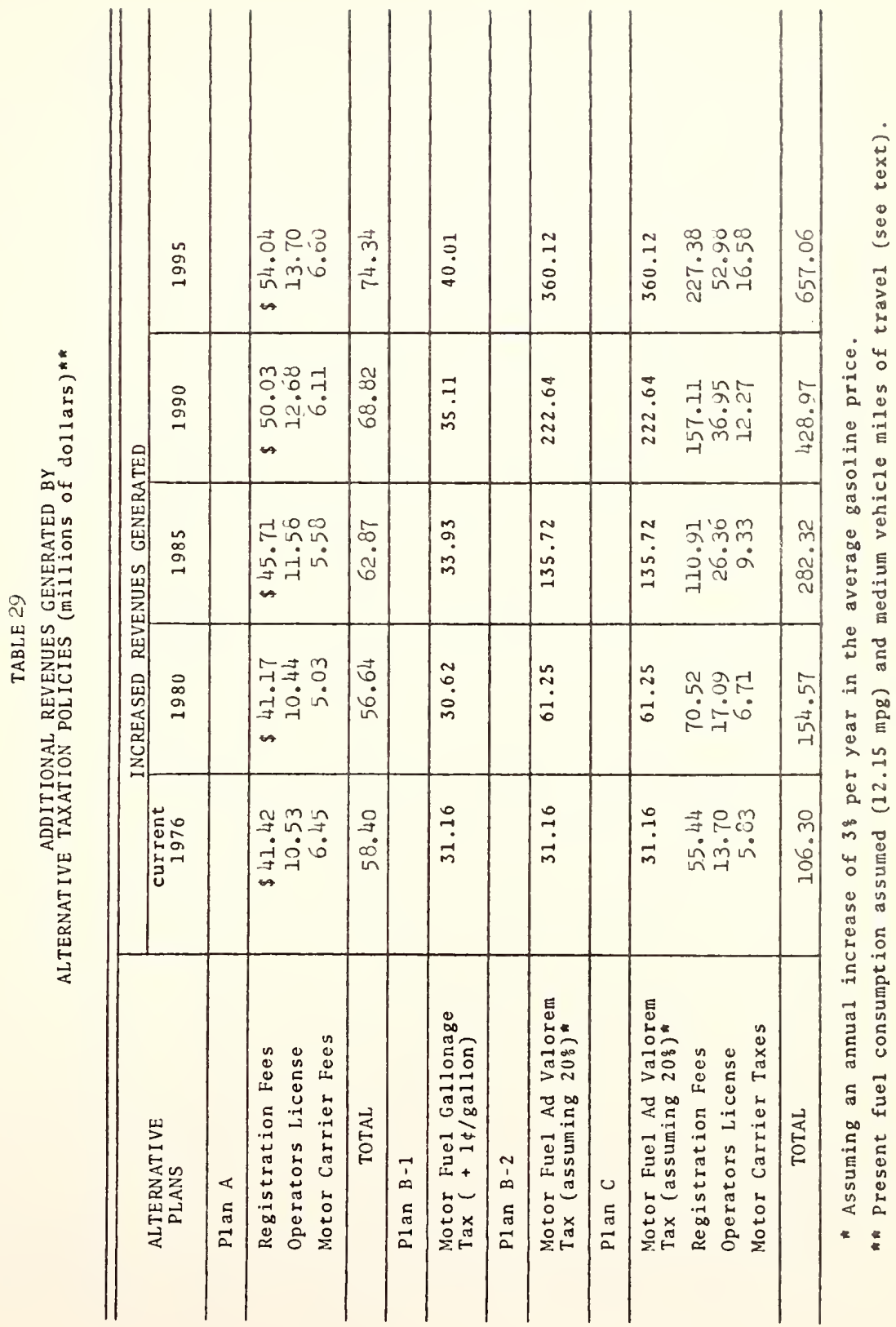




\section{Summary of Example B}

Example $B$ assumes changes only in the motor fuel tax and is thereby separated into 2 proposals, B-1 and B-2. B-I assumes a one cent per gallon increase to the present eight cent per gallon tax, making a total fuel tax of nine cents per gallon. Total user revenues generated by the per gallon flat rate fuel tax alternatives of ten and twelve cents, along with the effects that fuel consumption and vehicle miles of travel will have on these revenues, up to 1995, are shown in Table 30. Example B-I would produce an additional 31.16 million dollars now and $40 \mathrm{mil}$ lion dollars in 1995, which would make it a less favorable alternative than example $A$, considering revenues produced.

Example $B-2$ also assumes an increase in the fuel tax. However, this alternative proposes ad valorem rather than specific fuel taxation. P1an B-2 is calculated assuming a 20 percent ad valorem tax on the retail fue 1 price minus State and Federal taxes. The price of gasoline was projected to increase at the rate of 3 percent per year. While over the period of 1950 to 1973 the price of gasoline increased at an average annual growth rate of 1.6 percent, after the oil embargo of 1974 , the price of gasoline increased 35 percent over 1973 prices. Therefore, a projected 3 percent growth rate is not considered unreasonable. Table 31 summarizes these projected motor fuel prices exclusive of any State or Federal tax. 
TABLE 30

HIGHWAY USER REVENUE ESTIMATES' PER GALLON ASSUMPTIONS (millions of dollors)

\begin{tabular}{|c|c|c|c|c|c|c|c|c|c|c|c|}
\hline & \multicolumn{3}{|c|}{ Vohicl } & Milo & of & vel & \multicolumn{3}{|c|}{ Assumptions 2} \\
\hline & & & \multicolumn{3}{|c|}{ LOW } & \multicolumn{3}{|c|}{ MEDIUM } & \multicolumn{3}{|c|}{$\mathrm{HIGH}$} \\
\hline & & & \multicolumn{3}{|c|}{$\begin{array}{l}\text { TAX ASSUMPTION } \\
\text { (cents/gollon) }\end{array}$} & \multicolumn{3}{|c|}{$\begin{array}{l}\text { TAX ASSUMPTION } \\
\text { (cents/gallon) }\end{array}$} & \multicolumn{3}{|c|}{$\begin{array}{l}\text { TAX ASSUMPTION } \\
\text { (cenis/gollon) }\end{array}$} \\
\hline & & & .08 & .10 & .12 & .08 & 10 & .12 & .08 & .10 & .12 \\
\hline \multirow{3}{*}{$\begin{array}{l}\text { 옹 } \\
\text { O్ } \\
\text { - }\end{array}$} & \multirow{3}{*}{ 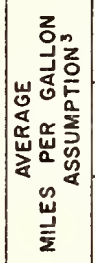 } & 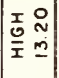 & 317 & 379 & 442 & 322 & 385 & 447 & 331 & 395 & 460 \\
\hline & & 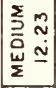 & 333 & 424 & 470 & 342 & 409 & 478 & 351 & 420 & 483 \\
\hline & & בั & 340 & 406 & 474 & 344 & 413 & 433 & 353 & 422 & 493 \\
\hline \multirow{3}{*}{$\begin{array}{l}\infty \\
\infty \\
\tilde{\sigma}\end{array}$} & \multirow{3}{*}{ 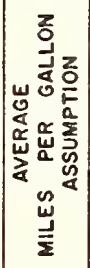 } & \begin{tabular}{ll}
\multicolumn{1}{|c}{} & 0 \\
$\frac{0}{1}$ & 0 \\
\hdashline & 0 \\
\hdashline
\end{tabular} & 313 & 374 & 432 & 325 & 335 & 447 & 340 & 425 & 469 \\
\hline & & 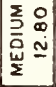 & 355 & 425 & 492 & 367 & 433 & 509 & 335 & 460 & 535 \\
\hline & & ב⿳⺈ & 370 & 442 & 515 & 332 & 453 & 533 & 400 & 430 & 560 \\
\hline \multirow{3}{*}{$\begin{array}{l}\text { ㅇ } \\
\text { o }\end{array}$} & \multirow{3}{*}{ 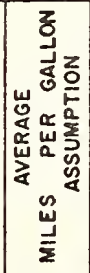 } & 甹음 & 338 & 364 & 421 & 324 & 332 & 440 & 345 & 407 & 471 \\
\hline & & 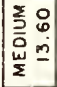 & 366 & 436 & 506 & 384 & 456 & 531 & 409 & 439 & 567 \\
\hline & & 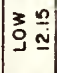 & 400 & 477 & 558 & 413 & 502 & 534 & 447 & 536 & 624 \\
\hline \multirow{3}{*}{$\begin{array}{l}\stackrel{\Omega}{\alpha} \\
\stackrel{\alpha}{\alpha}\end{array}$} & \multirow{3}{*}{ 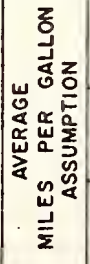 } & 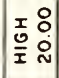 & 296 & 349 & 400 & 313 & 365 & 420 & 338 & 398 & 456 \\
\hline & & 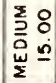 & 366 & 434 & 504 & 384 & 456 & 527 & 416 & 495 & 575 \\
\hline & & نِ & 430 & 515 & 600 & 451 & 540 & 629 & 491 & 587 & 684 \\
\hline
\end{tabular}

1 - Exclude Foderal Funds.

2 - For epecific volues see pexl.

3 - Averoge for Autos, Trucks, Buses- Totol floot mix. 
Table 31

Projected Motor Fue1 Prices 1980 - 1995*

Year

Motor Fuel

Retail Price
Adjusted Price

$(-.12 \notin$ State \& Federal Tax)

$\begin{array}{lll}1974 \text { (base year) } & .5241 & .4041 \\ 1980 & .6258 & .5058 \\ 1985 & .7255 & .6055 \\ 1990 & .8410 & .7210 \\ 1995 & .9750 & .8550\end{array}$

* Assuming a $3 \%$ per year fuel price increase

These projected adjusted prices were calculated as fo11ows:

Where:

$$
Y=X_{1}(1+.03)^{n}-.12
$$

$$
\begin{aligned}
\mathrm{Y}= & \text { estimated retail gasoline price minus } 8 \phi \\
& \text { State tax, minus } 4 \phi \text { Federal tax, given a } \\
& 3 \text { percent per year increase in retail motor } \\
& \text { fuel prices. } \\
\mathrm{X}_{1}= & \text { base year price from which calculations } \\
& \text { were made. } \\
\mathrm{n}= & \text { number of time periods from the base year. }
\end{aligned}
$$

These projected adjusted prices for motor fuel are used to calculate the ad valorem tax rate for three different percentages as shown in Table 32. This Table shows the ad valorem tax as converted to the actual pump price tax per gallon for selected years. At the 20 percent rate, fuel tax values vary from 10 cents per gallon in 1980 to 17 cents per gallon in 1995. These figures are 
not unreasonable as Connecticut currently levies an 11 cent per gallon State tax.

\section{Table 32}

\section{Ad Valorem Tax Conversions \\ (cents per gallon)}

\begin{tabular}{l|l|lll}
\hline \multirow{2}{*}{ Year } & \multirow{2}{*}{ Base } & \multicolumn{3}{|c}{ Ad Valorem Tax } \\
\cline { 3 - 5 } & & $15 \%$ & $20 \%$ & $25 \%$ \\
\hline 1980 & .5058 & .08 & .10 & .13 \\
1985 & .6055 & .09 & .12 & .15 \\
1990 & .7210 & .11 & .14 & .18 \\
1995 & .8550 & .13 & .17 & .21 \\
\hline
\end{tabular}

The implementation of a 20 percent ad valorem tax, as shown here, would have the effect of generating an additional amount of 31.16 million dollars of fuel revenue in 1976 and an estimated additional amount of fuel revenue of 360.12 million in 1995. This represents a substantial increase in user revenues. It should be noted that these figures are based on present fuel consumption rate and estimated medium vehicle miles of travel. Values with other assumptions about fuel consumption rate, levels of vehicle miles of travel, and different percentages for ad valorem tax may be calculated using Table 33. From this Table it may be noted in particular, the large revenues that can be generated by an ad valorem tax as compared with the flat per gallon assumptions as were shown in Table 30 . 
TABLE 33

HIGHWAY USER REVENUE ESTIMATES' $A D$ VALOREM ASSUMPTIONS (millions of doliors)

\begin{tabular}{|c|c|c|c|c|c|c|c|c|c|c|c|}
\hline & \multirow{2}{*}{\multicolumn{3}{|c|}{ Vohiclo }} & \multicolumn{6}{|c|}{ Assumptions 2} \\
\hline & & & & & & & MED!U & & & $\mathrm{HIGH}$ & \\
\hline & & & \multicolumn{3}{|c|}{$\begin{array}{l}\text { AD VALOREM TAX } \\
\% \text { of retoil price }\end{array}$} & \multicolumn{3}{|c|}{$\begin{array}{l}\text { AD VALOREM TAX } \\
\% \text { of retail pric } \theta^{4}\end{array}$} & \multicolumn{3}{|c|}{$\begin{array}{l}\text { AD VALOREM TAX } \\
\% \text { of retoil price }\end{array}$} \\
\hline & & & $15 \%$ & $20 \%$ & $25 \%$ & $15 \%$ & $20 \%$ & $25 \%$ & $15 \%$ & $20 \%$ & $25 \%$ \\
\hline \multirow{3}{*}{$\begin{array}{l}0 \\
\infty \\
\sigma \\
-\end{array}$} & \multirow{3}{*}{ 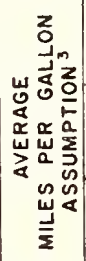 } & \begin{tabular}{ll}
\multicolumn{1}{r}{} & 0 \\
0 & $\stackrel{1}{x}$ \\
& $\cdots$
\end{tabular} & 317 & 379 & 472 & 322 & 385 & 479 & 331 & 395 & 491 \\
\hline & & 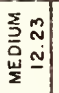 & 337 & 404 & 504 & 342 & 410 & 511 & 351 & 420 & 525 \\
\hline & & 30 & 339 & 406 & 506 & 344 & 412 & 514 & 353 & 423 & 528 \\
\hline \multirow{3}{*}{$\begin{array}{l}n \\
\infty \\
\sigma\end{array}$} & \multirow{3}{*}{ 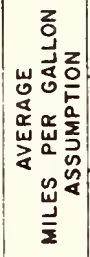 } & \begin{tabular}{ll}
\multicolumn{1}{c}{} & 0 \\
0 & 0 \\
I & $\underline{6}$
\end{tabular} & 344 & 432 & 521 & 355 & 447 & 538 & 373 & 469 & 565 \\
\hline & & 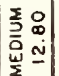 & 389 & 493 & 597 & 402 & 510 & 617 & 422 & 535 & 648 \\
\hline & & $3 \frac{n}{\underline{N}}$ & 400 & 515 & 625 & 420 & 533 & 646 & 440 & 559 & 673 \\
\hline \multirow{3}{*}{$\begin{array}{l}\circ \\
\text { \% } \\
\sigma \\
-\end{array}$} & \multirow{3}{*}{ 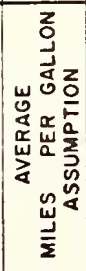 } & 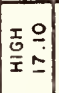 & 392 & 476 & 533 & 411 & 499 & 616 & 439 & 534 & 659 \\
\hline & & 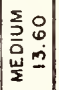 & 471 & 577 & 717 & 494 & 604 & 752 & 523 & 647 & 305 \\
\hline & & $\begin{array}{ll}3 & 0 \\
9 & \end{array}$ & 517 & 635 & 792 & 542 & 666 & 831 & 580 & 713 & $\$ 89$ \\
\hline \multirow{3}{*}{$\begin{array}{l}\mathscr{\Omega} \\
\text { の } \\
\text { ต }\end{array}$} & \multirow{3}{*}{ 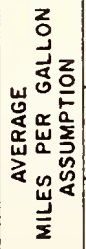 } & 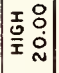 & 426 & 529 & 632 & 447 & 555 & 663 & 486 & 603 & 721 \\
\hline & & 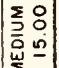 & 538 & 675 & 813 & 564 & 708 & 852 & 613 & 770 & 926 \\
\hline & & 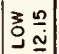 & 642 & 312 & 932 & 674 & 852 & 1029 & 732 & 926 & 1119 \\
\hline
\end{tabular}

1. Excluder Fodural Funde

2- For epeciol values tee test

3 - Averoge for Aulol, Trueke, Buace. Total flest mia

4- In Lies of stote tax, eicludes foderal tak 


\section{Summary of Example C}

Example $C$ combines examples $A$ and $B-2$ by utilizing a 20 percent ad valorem tax along with increasing the remaining user revenue structure to the same proportion as U.S. averages. The ad valorem tax was projected exactly as in example $\mathrm{B}-2$. The remaining user revenue structure increases were calculated using the same method as previously indicated in example $A$ of the preceeding chapter.

If currently applied, example $C$ would provide an additional 106.3 million dollars and in 1995 the substantial figure of 657.1 million dollars in additional revenue would be generated.

Figure 18 shows in a graphic form the relationships of the three examples along with the null or "do nothing" alternative. This null alternative assumes an eight cent per gallon fuel tax with existing fuel consumption rate. In addition the null alternative assumes that the vehicle miles of travel would follow the current trend which is the high estimate as used in this study. As it can be seen example C can provide the most revenue in 1995. 


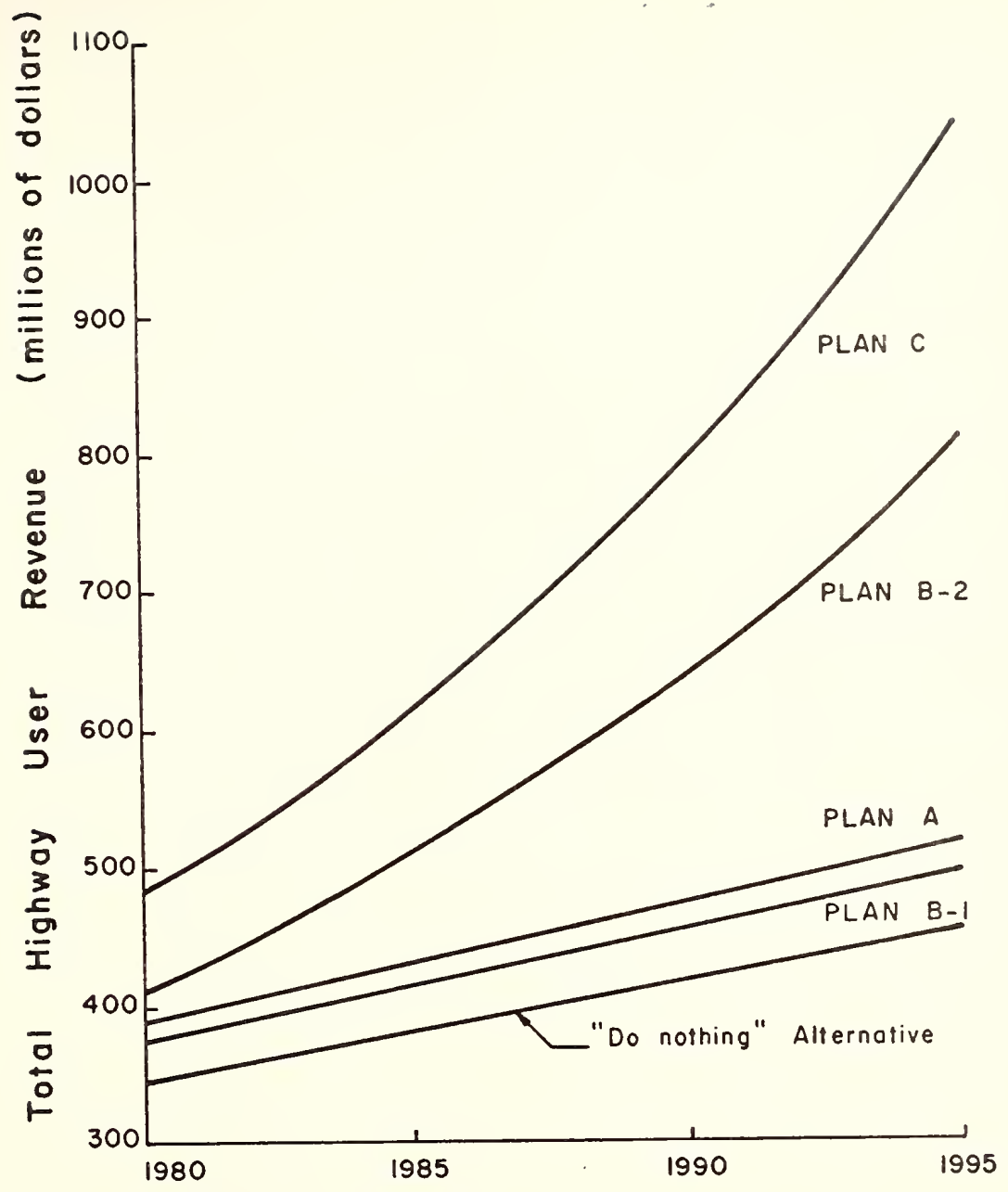

FIGURE 18 , HIGHWAY USER REVENUES GENERATED BY ALTERNATIVE PLANS. 
These data suggest that Indiana consider an ad valorem tax in lieu of the present per gallon motor fuel tax. The exact percentage of the ad valorem tax could be determined by the revenue needs projected by the upcoming Indiana Highway Needs Study. It is also suggested that maximum and minimum values (i.e. 9 to 12 cents) be established consistent with projected minimum needs and preventing windfall profits. In addition to an ad valorem taxation, the remaining components of the highway user revenue structure may be adjusted to conform to national percentages as indicated in this study. In particular, the truck registration fees are considerably lower compared to other midwestern states and these fees may be adjusted upward to produce additional revenue. 
CHAPTER VIII

CONCLUSIONS

Like most other states, Indiana is also struggling to maintain highways with insufficient highway revenues. This study examined some of the possible sources of additional revenues for Indiana highways. A sales tax on motor vehicles and vehicle parts is one possible source. As shown in Chapter IV, seven states now receive revenue from this impost. Indiana's motor vehicle registration fees can be adjusted to raise additional revenue; in particular the motor truck registration fees need special consideration as these are among the lowest of the midwestern states. At present, nine states are considering an escalating motor fuel tax such as an ad valorem tax on the retail fuel price per gallon. It is recognized that a periodic one or two cent fuel tax increase has been only a temporary solution to problems having long range financial implications. Many highway economists consider an ad valorem tax a long term solution to highway financing; this type of tax would have the effect of indexing highway revenues to general highway price inflation. 
It is recommended that; 1) a motor fuel ad valorem tax be given further study and consideration by Indiana decision makers, 2) the reproportioning of user revenue sources to national averages be examined with emphasis on a more equitable rate structure for truck registration, and 3) further study be made on supplementary taxation to raise highway revenue from such sources as imposition of a sales tax on vehicles and parts.

Only proper financial planning will provide adequate revenues for Indiana highways to continue to serve its population and provide for the needs of the nation. 
NOTES 
NOTES

1. Motor Vehicle Manufacturers Association of the United States, 1975 Automobile Facts and Figures, p. 37 .

2. Ibid., p. 58 .

3. United States Department of Transportation, Federal Highway Administration, Highway Statistics 1974.

4. Indiana, Department of Commerce, State of Indiana Transportation Needs Study 1972-A Summary, September, 1971 p. 22.

5. Richard A. Boehning, "Financing the Needs of the Indiana Highway System", Engineering Bulletin of Purdue University, Proceedings of the 61st Annual Road School, $1975, \mathrm{p} .120$.

6. Ronald L. Boner, Financing the Needs of the Indiana Highway System the Urban System", Engineering Bulletin of Purdue University, Proceedings of the 61st Annual Road School, 1975 p. 126.

7. M.E. Campbe11, "The Energy Outlook for Transportation in the United States", Traffic Quarterly April, 1973 p. 138 .

8. U.S. Department of Transportation, Highway Statistics, 1974, Table MF-2.

9. Anthony Downs, "The Law of Peak Hour Expressway Congestion", Traffic Quarterly, July 1962, p. 393.

10. Fredric C. Taslier, "Repairing the Ravages of an Urban Expressway", City Fal1 1971, p. 23.

11. David A. Crane, "Social, Economic and Environmental Consequences of Not Constructing a Transportation Facility", NCHRP Project 8-11, 1975.

12. U.S. Dept. of Transportation, 1974 National Transportation Report, July 1975. 
13. Indiana State Highway Commission, 1969-1973 Progress Report of the Indiana State Highway Commission, (Lafayette: Haywood Pub. Co., 1972) p. 36.

14. United States Department of Transportation, 1974

National Transportation Report: Current Performance and Future Prospects, Washington D.C. July 1975.

15. Boehning, "Financing the Needs of the Indiana State Highway System", Engineering Bulletin of Purdue University, 1975, p. 120 .

16. Harold M. Groves and Robert L. Bish, Financing Government 7 th edition, (Holt, Rinehart and Winston, Inc. 1973).

17. Robley Winfrey, Economic Analysis for Highways, (Scranton: International Textbook Company, 1969) p. 609 .

18. John Rapp, "Cost Allocation Revisited", Highway Research News, Highway Research Board, No. 17, Fe b. 1965 p.11.

19. Winfrey, Economic Analysis for Highways, p. 610.

20. Ibid. p. 611 .

21. United States Department of Commerce, Bureau of Public Roads Highway Cost Allocation Study, 87 th Congress, 1 st Se ssion House Doc. No. 72, 1961 .

22. H.L. Michael and J.A. Metcalfe, Financing the Highway Needs of Indiana, Joint Highway Research Project, Purdue University, February, 1969.

23. Winfrey, Economic Analysis for Highways, p. 613.

24. H.L. Michael and J.A. Metcalfe, Financing the Highway Needs of Indiana, p.23.

25. Ibid.

26. Winfrey, Economic Analysis for Highways, p. 620.

27. Ibid., p. 624 .

28. Ibid., p. 626 .

29. United States Department of Commerce, Bureau of Public Roads, Highway Cost Allocation Study, 1961.

30. Ibid. 
31. United States Department of Agriculture, Office of Public Roads. Public Road Mileage, Revenue, and Expenditures in the United States in 1904, U.S. Bulletin No. 32 Government Printing office, Washington, D.C. August 1907.

32. United States Department of Agriculture, Office of Public Roads and Rural Engineering. Automobile Registrations, Licenses and Revenues in the United States in 1916 , U.S. Government Printing Office, Washington, D.C. June 1917.

33. Winfrey, Economic Analysis for Highways, p. 606.

34. Ibid., p. 607.

35. H.L. Michael and J.A. Metcalfe, Financing the Highway Needs of Indiana, p. 37.

36. Indiana Commission of State Tax and Financing Policy, Studies in Indiana Finance, January, 1965 p. 18.

37. Ibid.

38. H.L. Michael and J.A. Metcalfe, Financing the Highway Needs of Indiana, p. 39.

39. Ibid.

40. Indiana Commission of State Tax and Financing Policy, Studies in Indiana Finance p. 26.

41. Cole and Williams Engineering, Joint Venture, Guidelines for Progress, Indiana Highways, Roads and Streets 19661985 I Report on Needs and Classifications, Indianapolis, Indiana January, $1967 \mathrm{p} .29$.

42. United States Department of Transportation, Federal Highway Administration, Highway Statistics, 1974.

43. Indiana State Highway Commission, Division of Accounting and Control, Budget Office Reports, June 30, 1974 p. 9.

44. Ibid., p. 8 .

45. Ibid., p. 9 .

46. Cole and Williams Engineering, Joint Venture, Guidelines For Progress, 1966-1985, Report on Finance, Indianapolis, Indiana 1967 p. 33 .

47. Ibid., p. 37 . 
48. United States Department of Transportation, Federal Highway Administration, Highway Statistics, 1974.

49. Utah Department of Transportation, Office of Policy and Systems Planning, Recommendation for Ad Valorem Tax, June 8, 1976.

50. Ibid., p. 5 .

51. Richard M. Zettel, From a Report prepared for the California Senate Committee on Transportatioß undated.

52. Cole and Williams Engineering, Guidelines for Progress, Indiana Highways, Roads and Streets 1966-1985, January 1967 and U.S. Department of Transportation, 1974 National Highway Needs Report 1975, Washington, D.C.

53. U.S. Bureau of the Census, Current Population Reports, Series P-95. Government Printing Office, Washington, D.C.

54. Ibid.

55. W. H. Bottiny, "Trends in Automobile Ownership and Indicators of Saturation." Highway Research Record \#106. Highway Research Board.

56. Ibid.

57. The data for these alternatives taken from Motor Vehicle Facts and Figures 1976, p.93, Motor Vehicle Manufacturers Association, Detroit, Michigan. 
LIST OF REFERENCES 


\section{LIST OF REFERENCES}

Anderson, Howard L., "Financing the Needs of the Indiana Highway System - The Federal Perspective." Proceedings of the 61 st Annual Road School 1975. Engineering Bulletin of Purdue University.

Baldcock, R. H., "The Annual Cost of Highways." Highway Research Record \#12, Highway Research Board, 1963.

Bielak, S. F. and J. F. McCarthy, "Highway Income, Expenditures, and User Tax Earnings in SMSA's." Highway Research Record No. 106, Highway Research Board.

Boehning, Richard A., "Financing the Needs of the Indiana Highway System." Proceedings of the 61st Annual Road School 1975. Engineering Bulletin of Purdue University.

Bonar, Ronald L., "Financing the Needs of the Indiana Highway System the Urban System." Proceedings of the 61st Annual Road School 1975. Engineering Bulletin of Purdue University.

Bottiny, W. H., "Trends in Automobile Ownership and Indicators of Saturation." Highway Research Record \# 106. Highway Research Board.

Bottiny, Walter H. and Beatrice T. Goley, "Projecting Automobile Availability by Urbanized Area." Highway Research Record \# 285. Highway Research Board.

Buckley, R. P., "States of Federal-Aid Highway Programs and the Highway Trust Fund." Traffic Engineering. January, 1972 .

Burch, Philip H., Highway Revenue and Expenditure Policy in the United States. Rutgers University Press, New Brunswick, New Jersey, 1962 .

Campbe11, M. E., "The Energy Outlook for Transportation in the United States." Traffic Quarterly. April, 1973. 
Cole and Williams Engineering, Guidelines for Progress Indiana Highways, Roads and Streets 1966-1968.

Vo1. I. Report on Needs and Classification. Vol II. Report on Finance. Vo1. III. Summary Report.

Cook, K. E. and P. A. Rush, "Concumer Awareness of Motor Fuel Tax Rates and Prices." Highway Research Record \#138. Highway Research Board.

Crand, David A. and Partners, "Social, Economic and Environmental Consequences of Not Constructing a Transportation Facility." NCHRP Project 8-11 Part 1 \& 2. Transportation Research Board, 1976.

Doom, Ira F. and Marvin Tummins, Forecasting and Estimating. Virginia Highway Research Council, 1965.

Davie, Bruce F. and Bruce F. Duncombe, Public Finance. Holt, Rinehart and Winston, Inc. $19 \overline{72 .}$

Downs, Anthony, "The Law of Peak-Hour Expressway Congestion." Traffic Quarterly. July, 1962 .

Farre11, Fred B. "Effect of Traffic Growth Projections upon Estimates of Highway Needs \& Revenues." Highway Research Board Bullet in \# 158. 1956 Highway Needs Studies.

French, Alexander, "The Petroleum Challenge." Proceedings of the 60th Annual Road Schoo1 1974. Engineering Bulletin of Purdue University.

Graham, Arther E., "Impacts of the Fue1 Shortage on Highway Funds in Indiana." Proceedings of the 60th Annual Road School 1974. Engineering Bulletin of Purdue University.

Graves, Harold M. and Robert L. Bish, Financing Government. 7 th Edition. Holt, Rinehart and Winston, Inc. 1973.

Ha11ock, Gene K., "Indiana State Highway Commission Programs - Past and Future." Proceedings of the 61st Annual Road School 1975. Engineering Bulletin of Purdue University.

Hermanson, M. E., "State Level Program Budgeting Considerations." Highway Research Record \# 288. Highway Research Board, 1969.

Indiana Commission of State Tax and Financing Policy, Studies in Indiana Highway Finance, January, 1965. 
Indiana Department of Commerce, Division of Planning. State of Indiana Transportation Needs Study 1972-A Summary, U.S. Department of Transportation.

Indiana State Highway Commission, Division of Accounting and Control. Budget Office Reports. Fiscal Year Ending June $30,1975$.

Indiana State Highway Commission. Progress Report 19691973. Haywood Publishing Co., Lafayette, Indiana, 1972.

Interagency Task Force on Motor Vehicle Goals Beyond 1980. Fuels and Materials Resources for Automobiles in the 1980-1990 Decade and Marketing and Mobility, Office of the Secretary of Transportation, Publications section, TAD-443.1, Washington, D.C.

Lee, Robert R and E. L. Grant, "Inflation and Highway Economy Studies." Highway Research Record \#100. Highway Research Board.

Lindman, B. H., "Economic Forecasting for Statewide Highway Studies." Highway Research Board Bulletin \# 158. Highway Needs Studies, 1957.

Martin, Brian V. et.al., Principles and Techniques for predicting Future Demand for Urban Area Transportation. M.I.T. Report No. 3, M.I.T. Press, 1961.

Michae1, H. C. and J. A. Metcalfe, Financing the Needs of Indiana. Joint Highway Research Project, Purdue University, February, 1969.

Miller, Burton F., "The Role of Highways in Future Transportation Systems." Traffic Quarter1y. October, 1970.

Mohring, Herbert and Mitchell Horwitz, Highway Benefits, An Analytical Framework, Northwestern University Press, 1962 .

Motor Vehicle Manufacturers Association, Automobile Facts and Figures 1975, 1976. Detroit, Michigan.

Oregon Department of Transportation, Highway Division, Motor Vehicle Cost Responsibility Study, 1974.

Paterson, Robert W., Forecasting Techniques for Determining the Potential Demand for Highways. Business and Public Administration Research Center, University of Missouri, 1966. 
Paterson, Robert W., "Population Implications for Forecasting Highway Demand." Traffic Quarterly. January, 1970 .

Rankin, W. W. and R. J. Oravec, "Allocation and Apportionment of Highway Funds." ASCE Transportation Engineering Journal. May, 1973.

Rapp, John, "Cost Allocation Revisited." Highway Research News, No. 17. Highway Research Board. February, 1965.

Roth, Gabriel J., "Traffic Congestion as a Source of Revenue. Traffic Quarterly. April, 1970.

Sawchuk, Henry A., "The Impact of Materials and Fuel Shortages on Highway Construction and Maintenance." Proceedings of the 60th Annual Road School 1974. Engineering Bulletin of Purdue University.

South Dakota Department of Highways, "An Analysis of Techniques Used in Highway Studies by Various States." Highway Research News \#31. Highway Research Board, 1968.

Swartz, Thomas R., "The Economics of the Diesel Fuel Tax Differential." Highway Research Record \# 285. Highway Research Board.

Tasker, Fredric C., "Repairing the Ravages of an Urban Expressway." City. Fall, 1971.

Tummins, M. and W. R. Trenor, Forecasting and Estimating. Virginia Council of Highway Investigation, 1961.

U. S. Bureau of the Census, Current Population Reports, Series P-95, Government Printing Office, Washington, D.C.

U. S. Bureau of the Census, Statistical Abstract of the United States: 1975. Washington, D. C. Government Printing office.

U. S. Department of Commerce, Final Report of the Cost Allocation Study. House Document No. 54, 87th Congress First Session, 1961.

U. S. Department of Commerce, Bureau of Economic Analysis, Survey of Current Business. April, 1974.

U. S. Department of Transportation, Highway Statistics 1973, 1974. Federal Highway Administration. 
U. S. Department of Transportation, 1974 Nationa1 Highway Needs Report. February 10, 1975, 94th Congress, 1st Session, House Document No. 94-45, U. S. Government Printing Office, Washington, D. C., 1975.

U. S. Department of Transportation, The Highway Capital Problem. Federal Highway Administration, Office of Program and Policy Planning, August, 1975.

Utah Department of Transportation, Annual Plan Report, P1anning and Programming. August, 1975 .

Winfrey, John C., Public Finance, Public Choices and the Public Economy. Harper and Row, 1973.

Winfrey, Robley, Economic Analysis for Highways. 1969 International Textbook Company. Scranton, Pennsylvania.

Winfrey, Robley and T. R. Todd, "Financing Urvan Transportation." ASCE, Journal of the Highway Division. Vo1. 91, No. HWZ. December, 1965 .

Zion, Roger H., "Federal Financing of Transportation Trends and Policies." Proceedings of the 59th Annual Road School. Engineering Bulletin of Purdue University. 
APPENDICES 
Appendix A

Federal Aid to Indiana Highways

The major portion of revenues from Federal highway user taxes is credited to the Federal Highway Trust Fund which was established by the Highway Revenue Act of 1956. The Trust Fund now receives the federal revenues from the 4 cent per gallon gasoline, diesel and special fuels tax; the 6 cents per gallon tax on lubricating oil; the 10 cent per pound tax on highway tires and inner tubes; the 5 cent per pound tax on tread rubber; the 10 percent manufacturer's excise tax on buses, trucks and trailers; the 8 percent manufacturer's excise tax on parts and accessories; and the annual tax of $\$ 3.00$ per 1000 pounds on vehicles having a gross weight in excess of 26,000 pounds. Table 35 shows Indiana highway users estimated payments into the Highway Trust Fund and Federal apportionments from the fund. In 1974 Indiana had the lowest ratio of apportionments to payments of any state in the country. 


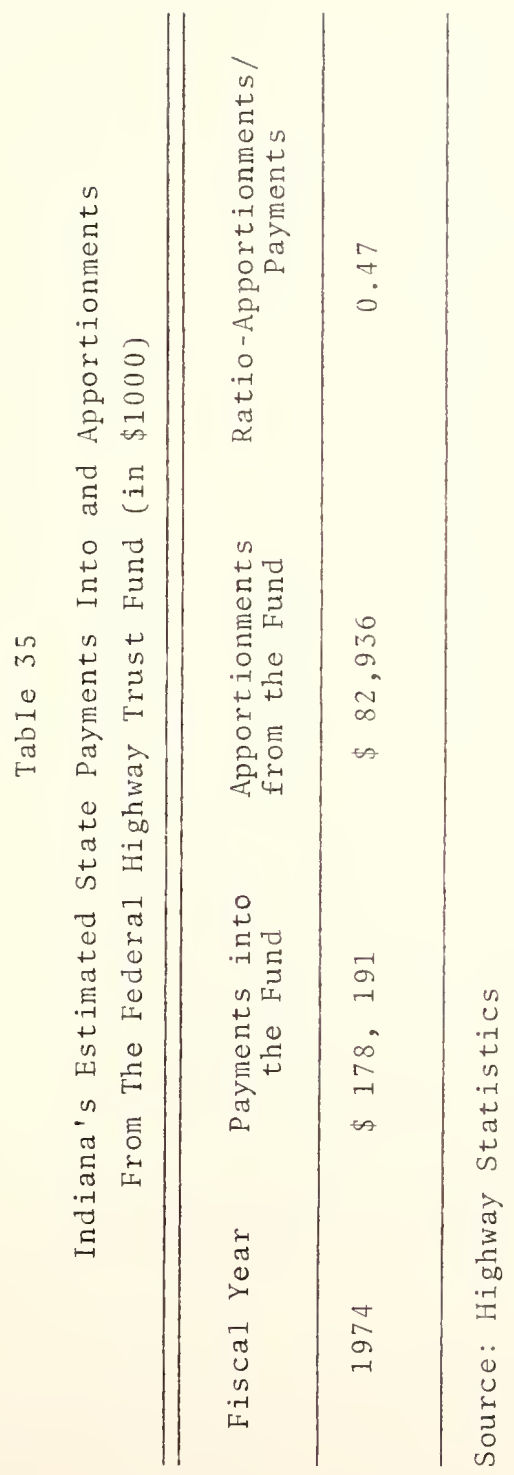




\section{Appendix B}

State Highway Revenue Questionnaire

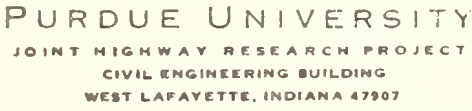

May 14, 1976

AND

Dear Sir:

The Joint Highway Research Project of Purdue University, School of Civil Engineering and the Indiana State Highway Commission is conducting a study of current practices in state highway financing.

The purpose of this research is to summarize current state highway revenue mechanisms and examine possible new sources of highway revenue for future years by creating an awareness of missed revenue opportunities. Many states are currently struggling with increased construction and maintenance costs while revenues are decreasing or at best, remaining the same. As the Interstate System nears its completion, the maintenance of an acceptable level of service for all state highways will become an increasingly dominant portion of the highway budget. Many states already project deficits running into billions of dollars in the next twenty years. For this reason, the Joint Highway Research Project is concerned with the steps your state is taking, or proposing, to maintain adequate revenues for the state highway system.

To obtain meaningful and pertinent results we need your input to this project. We would appreciate completion and return of this questionnaire as soon as possible. A self-addressed stamped envelope is enclosed for your convenience.

Thank you for your kind assistance with this project. We will be more than happy to forward a copy of this research to you, at your request, when completed.

Sincerely,

John R. McCarthy

Graduate Research Assistant

Joint Highway Research Project 
1. Which of the following revenue sources does your State employ for state highway financing? (Do not include county and local highway financing).

Revenue Source*

Oriver License, Title, Transfer \& Misc. Fees

Motor Carrier Fees

Weight-0istance Fees

Gross Receipts Taxes

Access Fees

Utility R.O.W. Use Fee

Roadside Advertising Fee

State Sales Tax

Sales Tax (Vehicles \&

Vehicle Parts)

State Income Tax

Alcoholic Beverage Tax

Cigarette Tax

Insurance Tax (On Motor

Vehicle Insurance)

Other Taxes (Please specify)
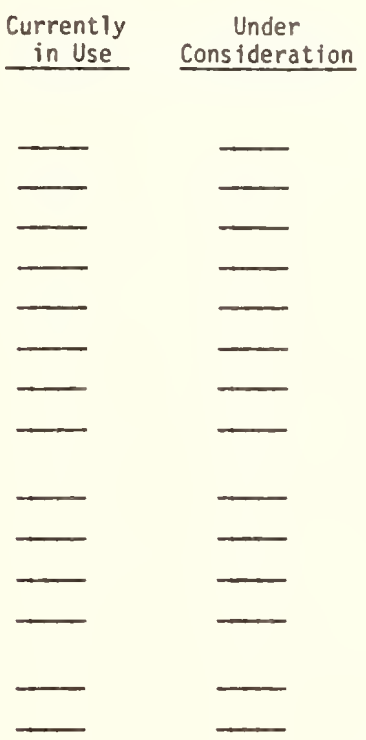

Net Revenues for State Highways $1975(\$ 1000)$

"NOTE: Questions on fuel taxation and vehicle registration are included below.

2. What types of gasoline tax do you presentiy use?
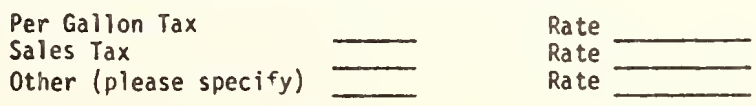

3. Has your State gasoline tax been changed within the past three years?

$$
\text { the year of change. No If yes, please state the changed rate and }
$$

4. Is there any legislation currently pending or imminent which involves gasoline tax changes in your State?
Y. Yes No
If yes, please state proposed changes.

5. What is your current diesel fuel tax? 
6. Do you tax special fuels such as liquified petroleum gas? Yes No If yes, please state rate.

7. Is there any legislation currently pending or imminent which involves diesel or special fuels?

$$
\overline{\text { rate. }}^{\text {Yes No If yes, please state source and proposed }}
$$

8. Does your State provide for taxation of fuel used in state, local or federal vehicles?

Y Yes No If yes, please specify taxation rate.

9. What is the basis for Registration of Passenger Cars?

Rate

Flat Fee

Empty Weight

Value

Age

Please specify any combinations or other criteria used for Passenger Car Registration.

10. What is the basis for Licensing Trucks and Trailers?

Rate

Declared Maximum Gross Weight

Empty, Actual or Unladen Weight

Manufacturers Rated Capacity

Please specify any combinations or other criteria used for Licensing Trucks and Trallers.

11. What legislative actions is your state involved in or will be taking in the near future, to balance the deficit between state highway costs and revenues in coming years? (Flease use back of page). 
Questionnaire Summary

Al abama

Alaska

Arizona

Arkans as

California

Colorado

Connecticut

Delaware

Florida

Georgia

Hawaii

Idaho

Illinois

Indiana

Iowa

Kans as

Kentucky

Louisiana

Maine

Maryl and

Massachusetts

Michigan

Minnesota

Mississippi

Missouri

Montana

Nebraska

Nevada

Gasoline

7

*

8

8.5

Rate Per Gallon ( $\phi$ )

7

7

11

9

*

7.5

8.5

9.5

Diese 1

8

*

8

9.5

Special Fuels

7.5

8

7

7

7

7

11

9

*

*

*

8

7.5

6

6

11

9

7.5

8.5

9.5

*

7.5

6

9.5

7.5

8

7.5

8

7

8

$*$

9

8

9

9

*

9

9

9

7

7.75

8.5

*

New Hampshire

New Jersey

9

*

New Mexico

New York

N. Carolina

N. Dakota

Ohio

Okl ahoma

7

8

9

7

7

6.58

9

9

8

9

9

none

9

*

9

9

10

*

7

9.75

none

8.5

*

8.5

$*$

none

9

*

7

10

7

8

$9 \quad 9$

7

7

7

6.5

none

* information not provided 
Questionnaire Summary contd.

Oregon

Pennsylvania

Rhode Island

S. Carolina

S. Dakota

Tennessee

Texas

Ut ah

Vermont

Virginia

Washington

W. Virginia

Wisconsin

Wyoming
Rate Per Gallon ( $\phi$ )

Gasoline

7

9

10

*

8

7

5

7

9

9

9

8.5

7

8
Diese 1

7

9

10

$*$

8

8

6.5

7

none

9

9

8.5

7

8
Special Fuels

7

none

10

6

7

5

7

none

*

9

8.5

none

* information not provided 
Questionnaire Summary contd.

Basis for Registration

Automobile

Trucks

Alabama
Alaska
Arizona
Arkansas
California
Colorado
Connecticut
Delaware
F1orida
Georgia
Hawai
Idaho
I11inois
Indiana
Iowa
Kansas
Kentucky
Louisiana
Maine
Maryland
Massachusetts
Michigan
Minnesota
Mississippi
Missouri
Montana
Nebraska
Nevada

flat fee

age, value

flat fee

gross weight

gross weight

empty weight

gross loaded

weight

flat fee

flat fee and

and value

empty weight

empty weight

flat fee

empty weight

rated capacity

flat fee

gross weight

empty weight

age

flat fee

flat fee and

excise $t a x$

age, value, empty weight

empty weight

f1at fee

flat fee

flat fee

empty weight

*

empty weight

value

weight

horsepower

empty weight

flat fee
*

$\max \cdot \underset{*}{\operatorname{gross}}$ weight

gross weight

gross weight

gross weight

gross weight

gross weight

max. gross weight

axle weight

declared max

gross weight

chassis weight

gross weight or

number of axles

*

empty weight

gross weight

gross weight

weight

max. gross weight

gross weight

* information not provided 


\section{Questionnaire Summary contd.}

Basis for Registration

Aut omobile

New Hampshire

New Jersey

New Mexico

New York

N. Carolina

N. Dakota

Ohio

Oklahoma

Oregon

Pennsylvania

Rhode Island

S. Carolina

S. Dakota

Tennessee

Texas

Utah

Vermont

Virginia

Washingt on

W. Virginia

Wiscons in

Wyoming empty weight

age \& weight

empty weight

flat fee

age \& empty

we ight

flat fee

value \& age

flat fee

flat fee

capacity \& empty

weight

age \& empty

weight

flat fee

empty weight

flat fee

flat fee

weight

flat fee

empty weight

and value

flat fee

flat fee

\section{Trucks}

gross weight

gross weight \& age

max. gross weight

gross weight

age \& gross weight

gross weight

axles \& weight

gross weight

max. gross weight

gross weight

*

age \& chassis

gross weight

actual weight \&

carrying capacity

$\max$. gross weight

gross weight

gross weight

gross weight

max. gross weight

gross weight

empty weight

* information not provided 


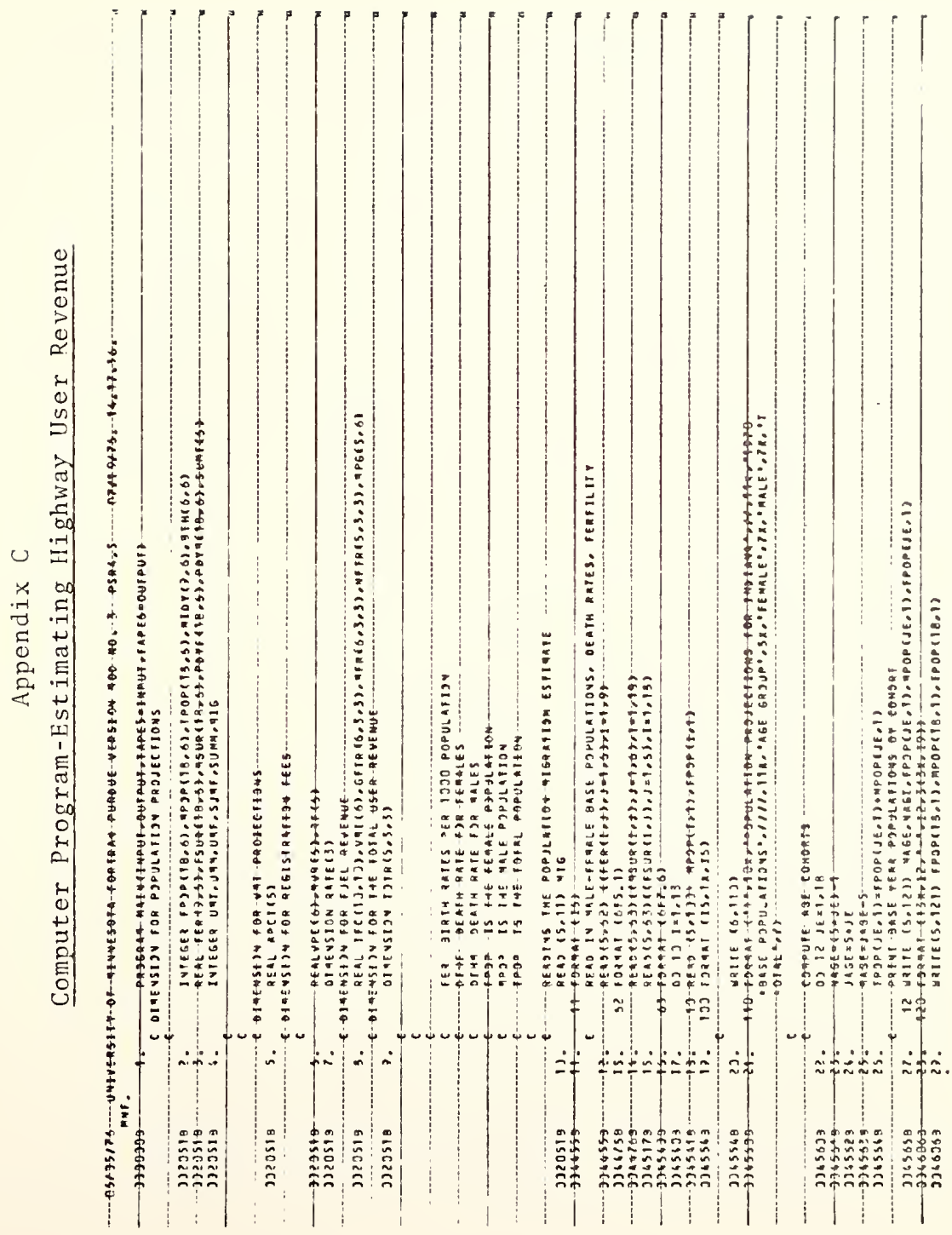




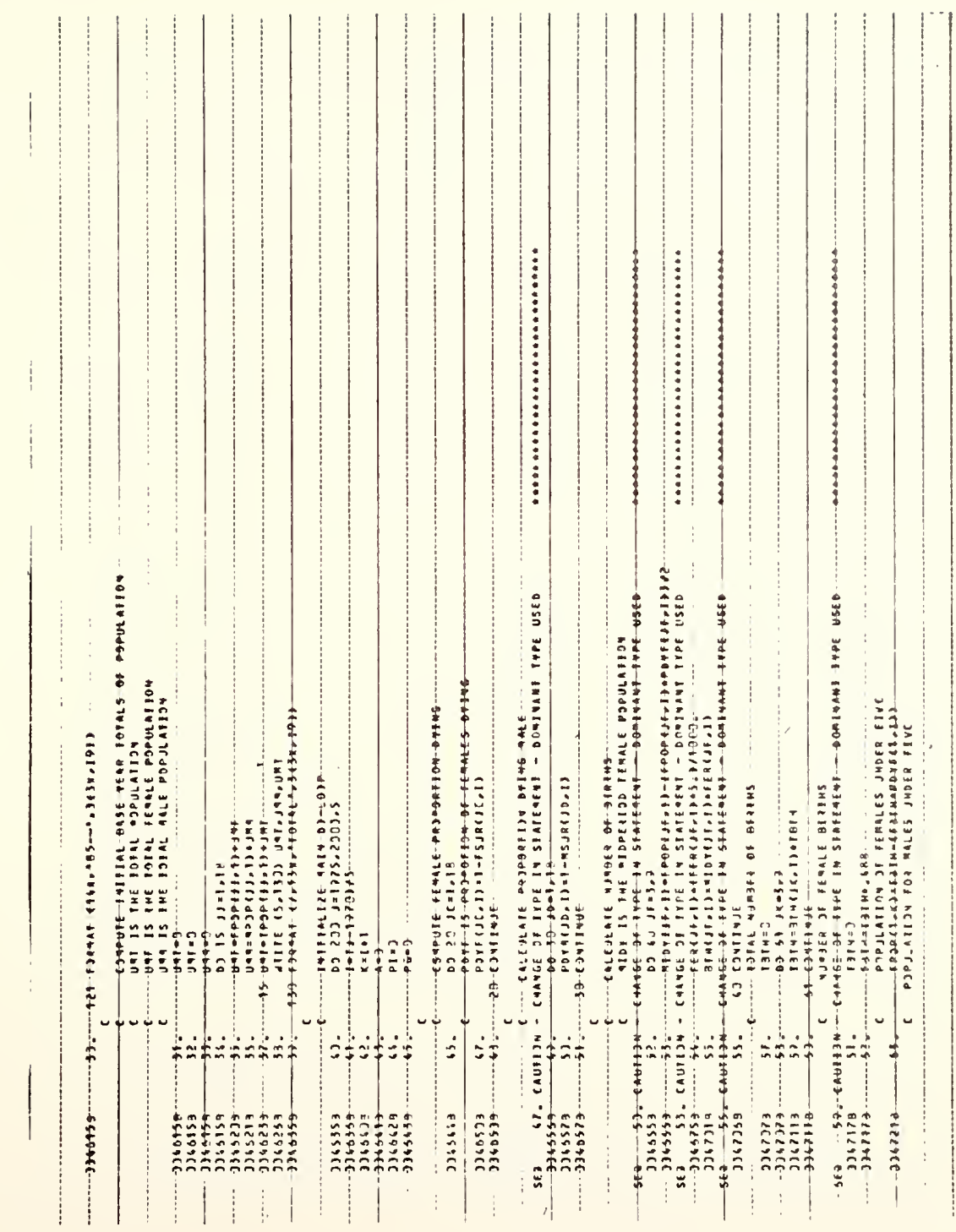




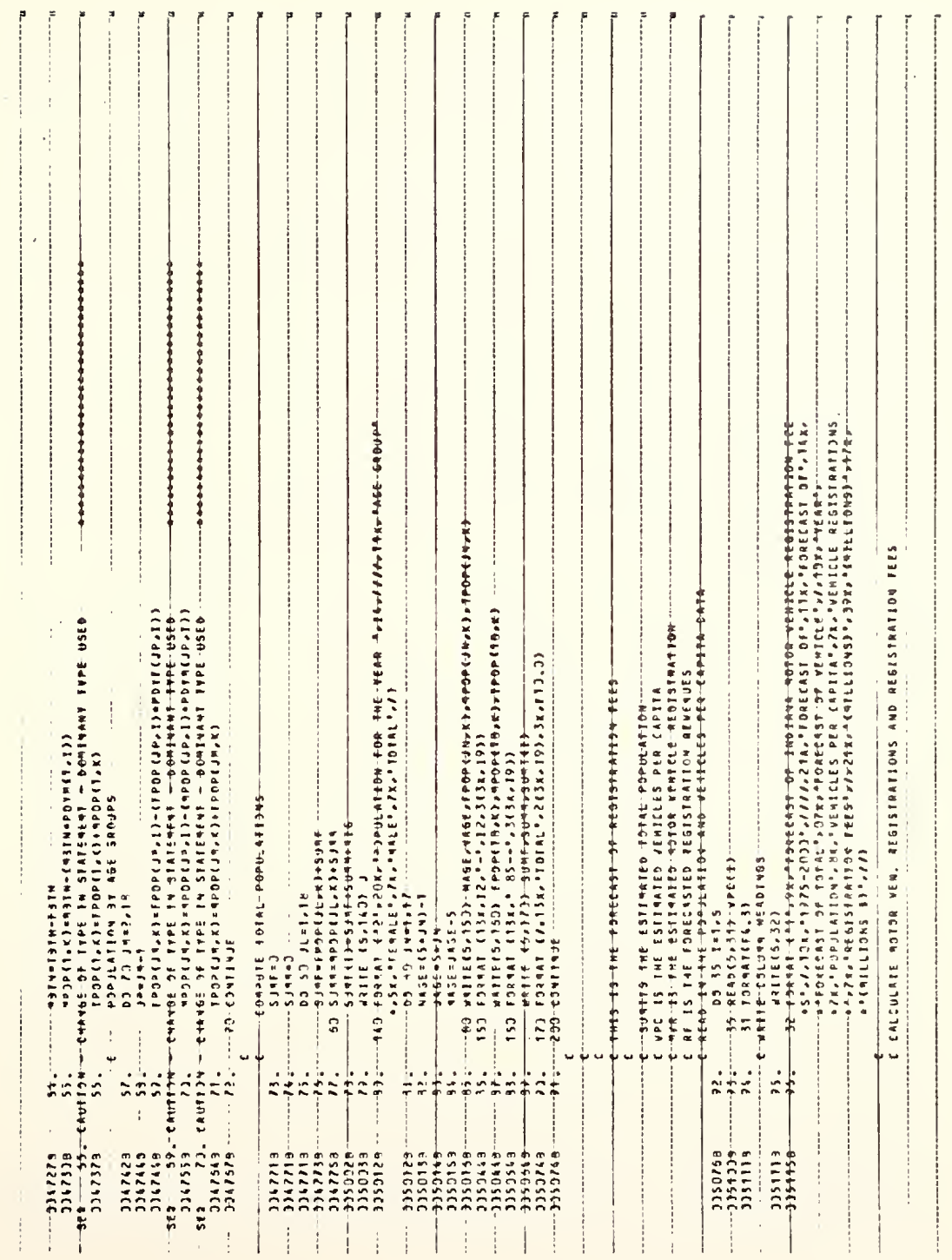




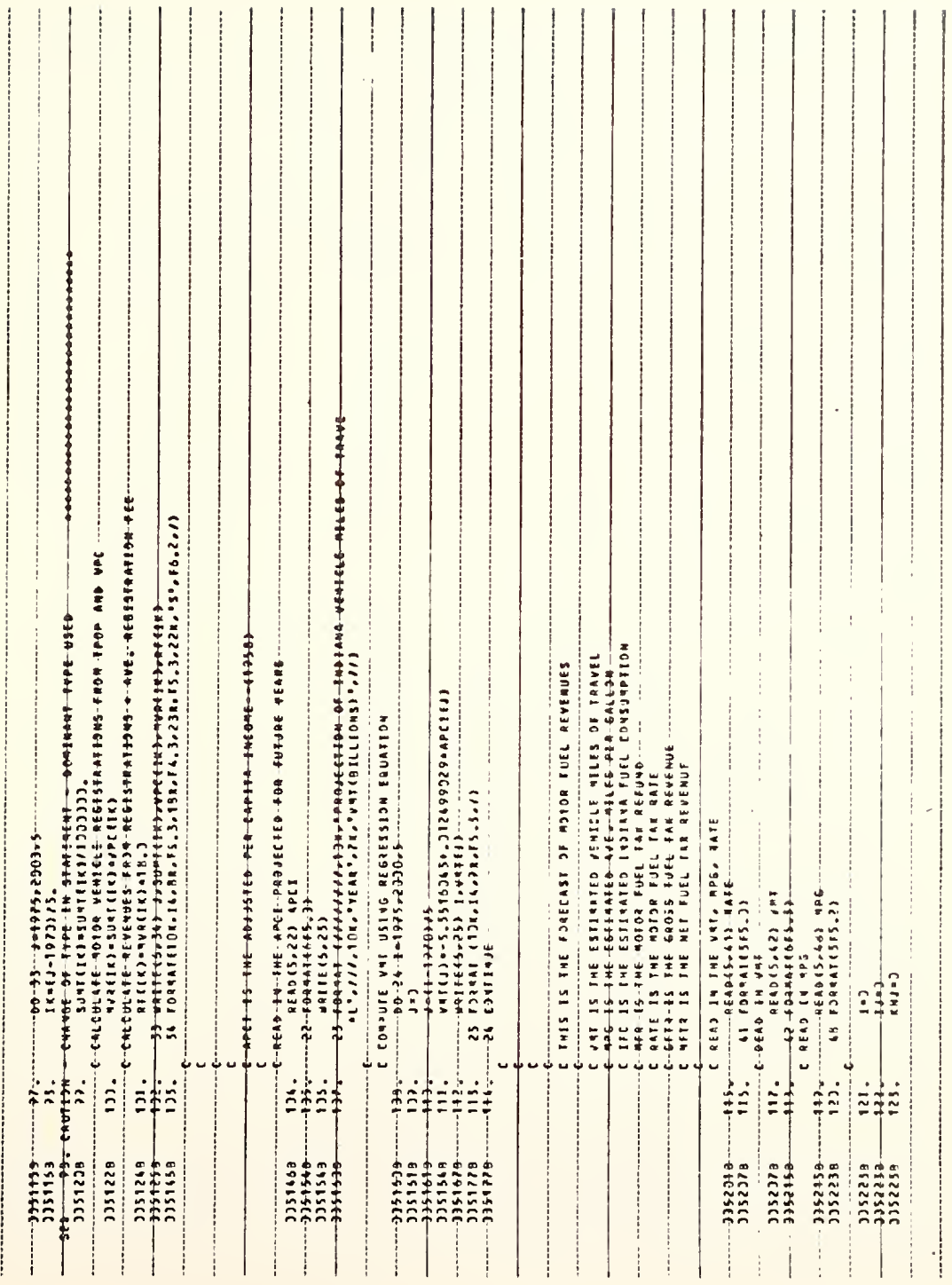




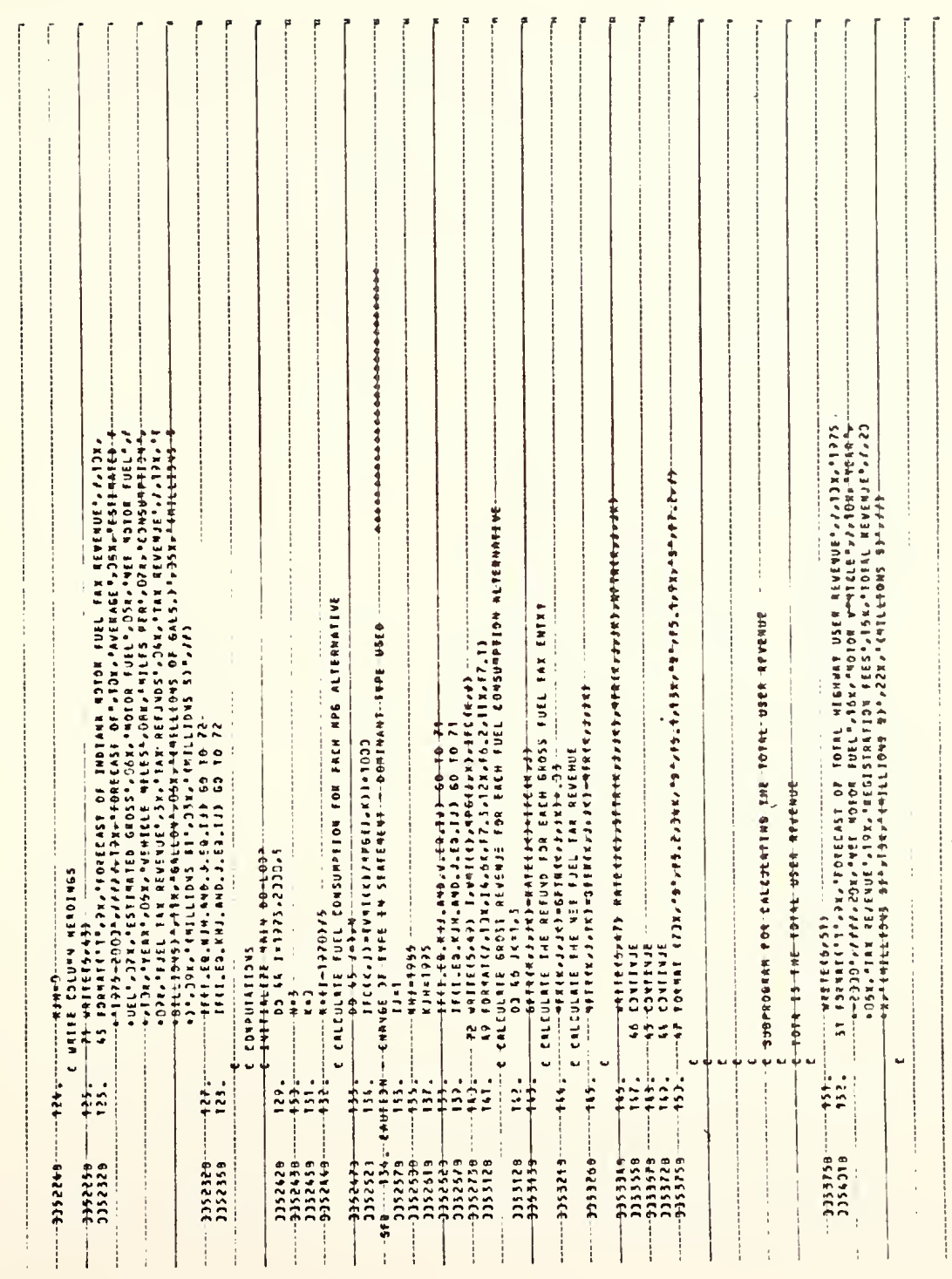




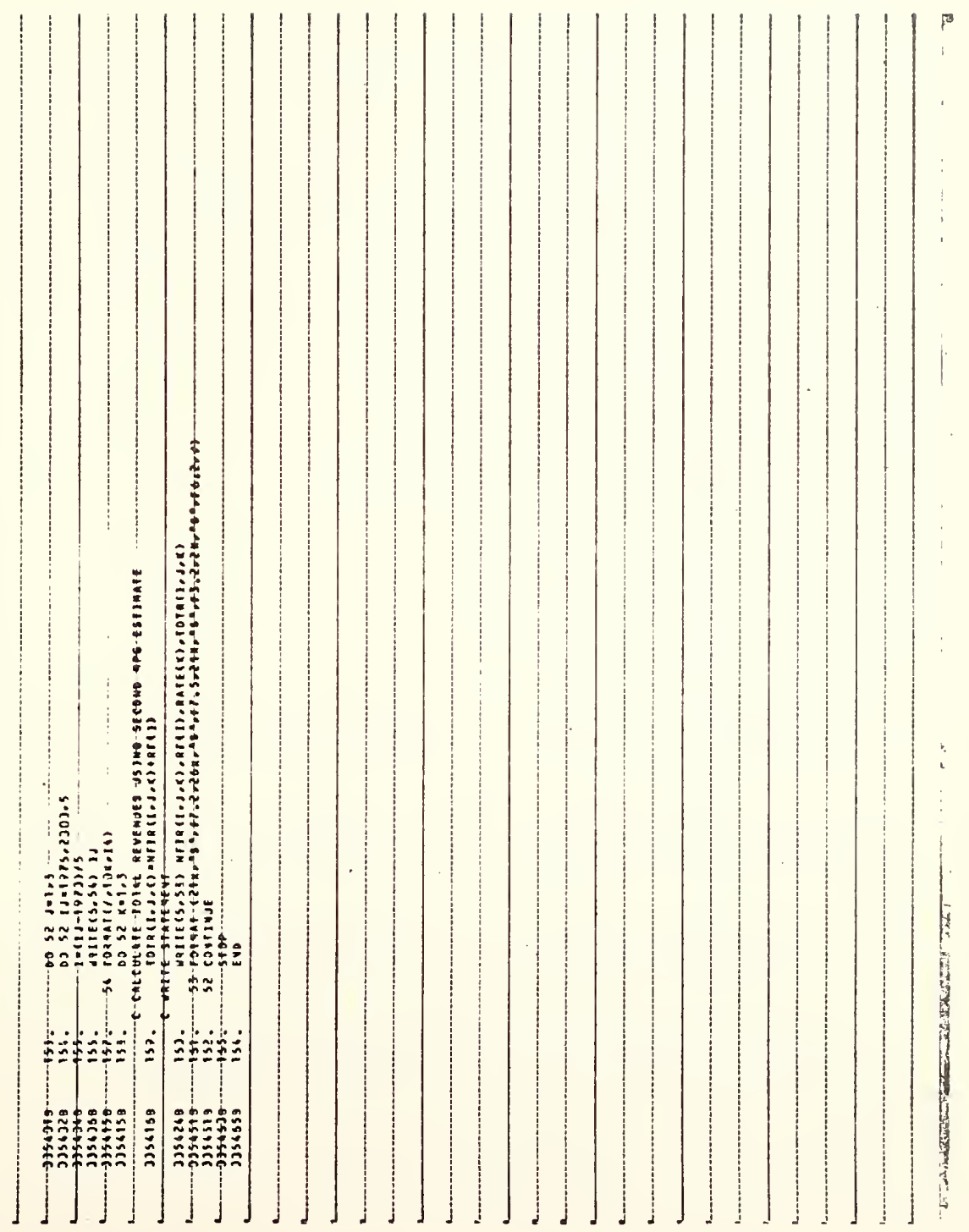




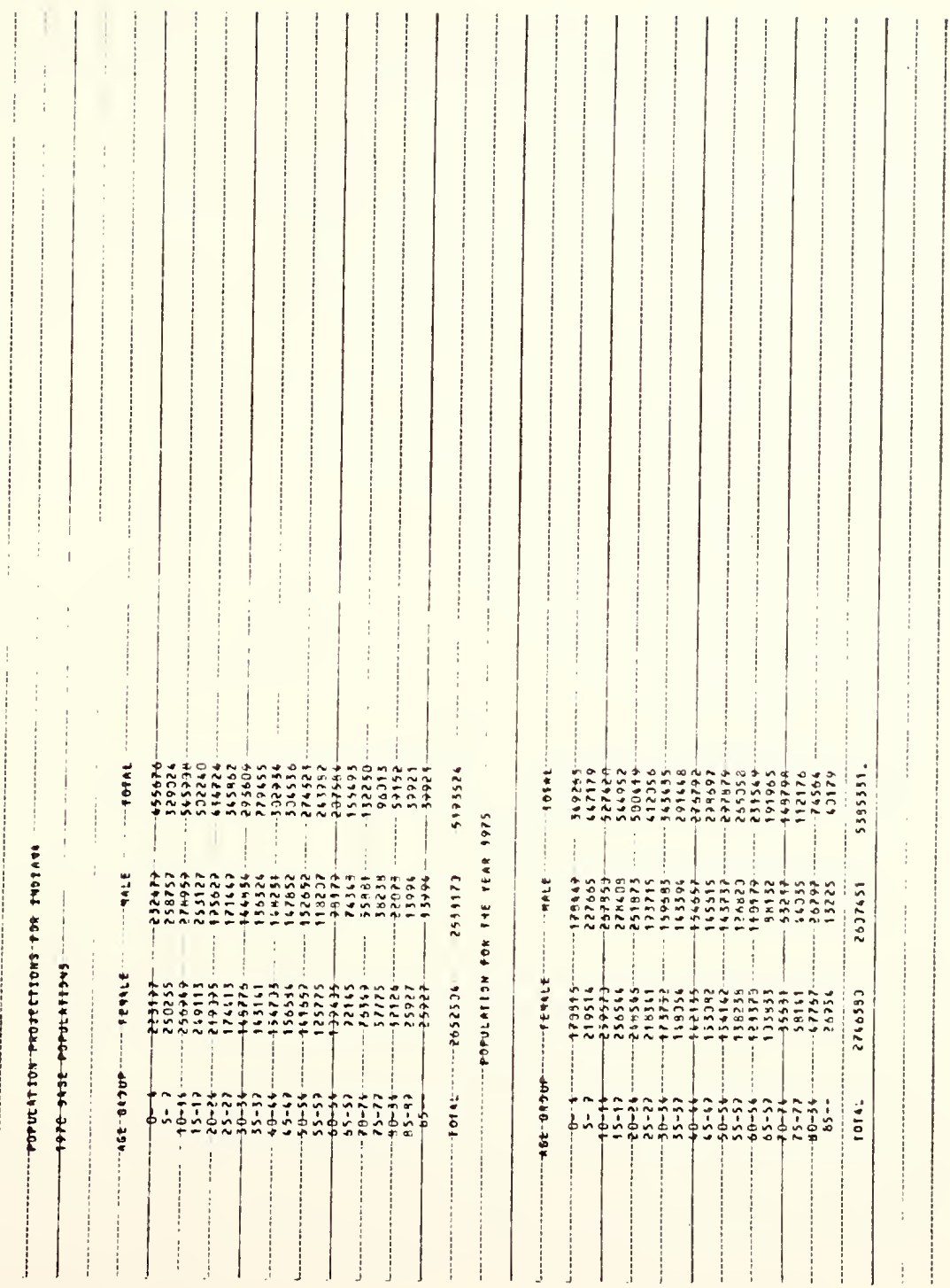




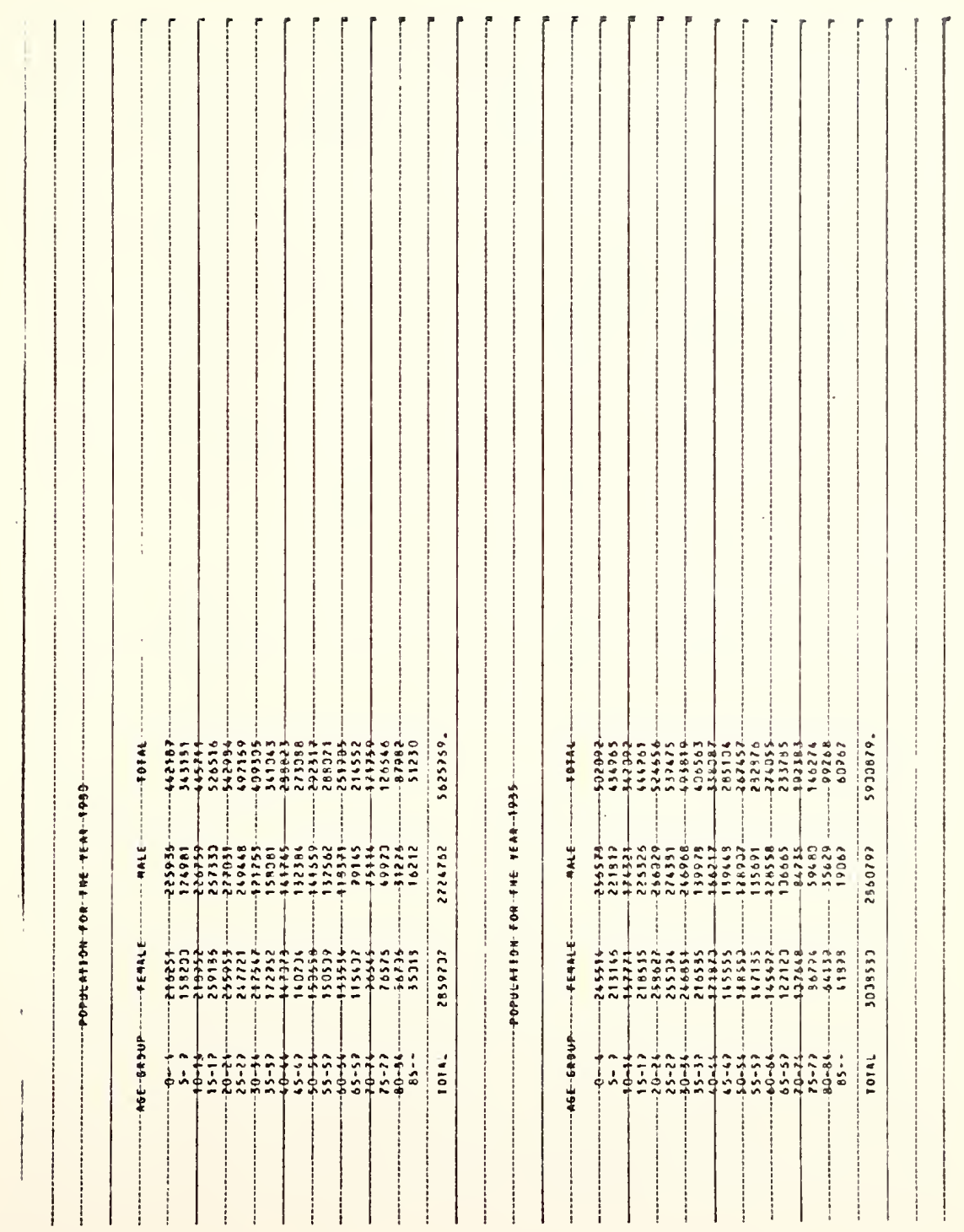




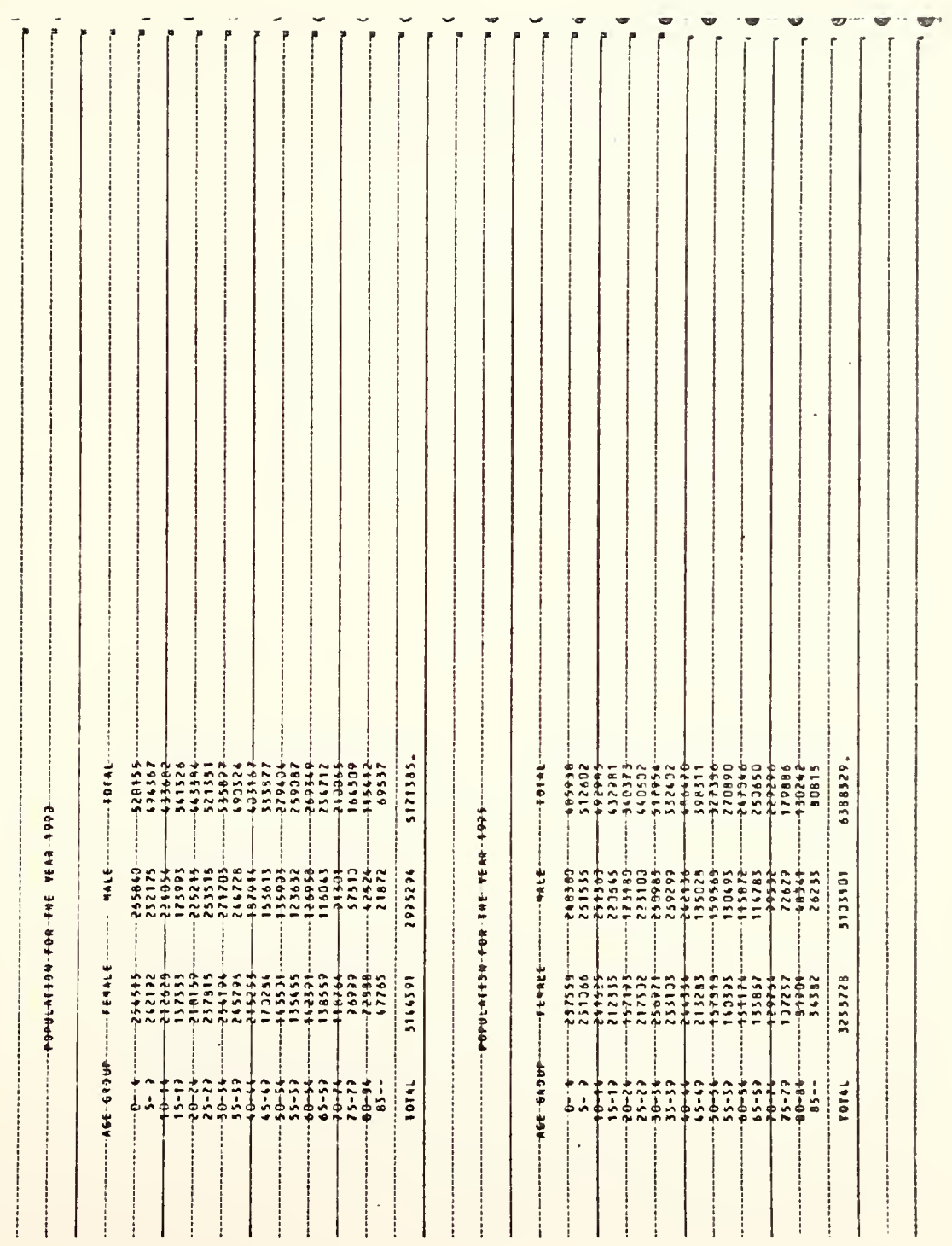




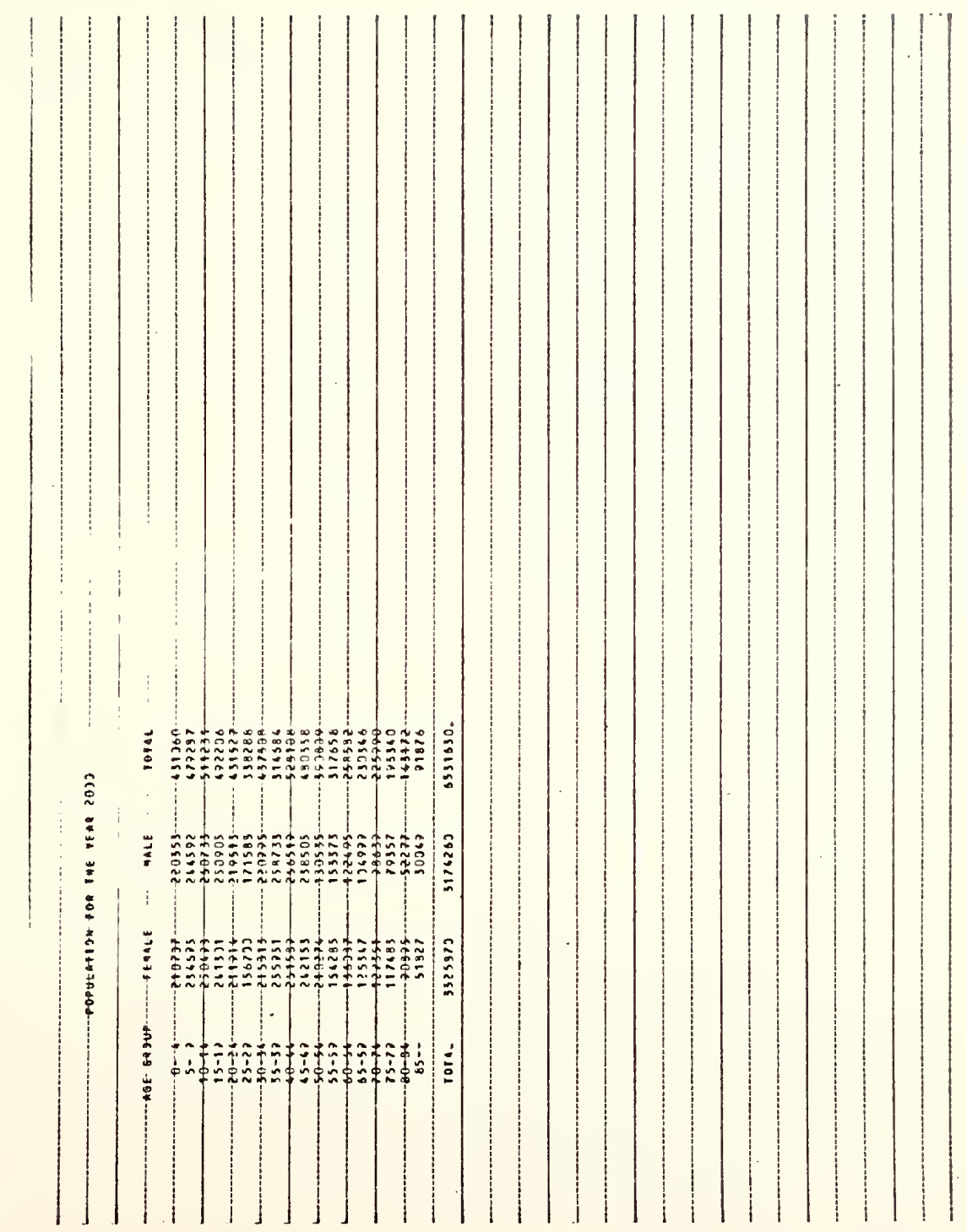




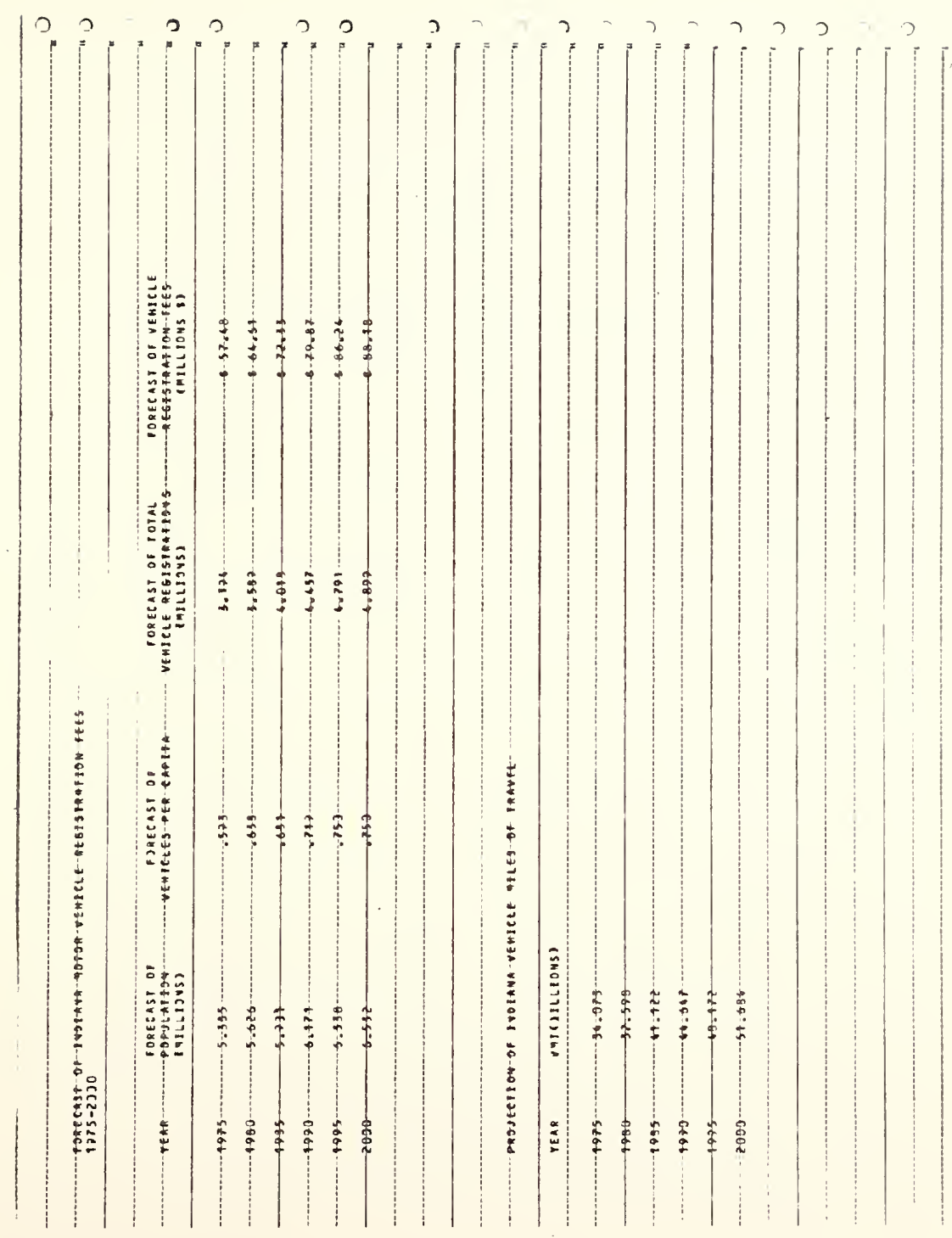




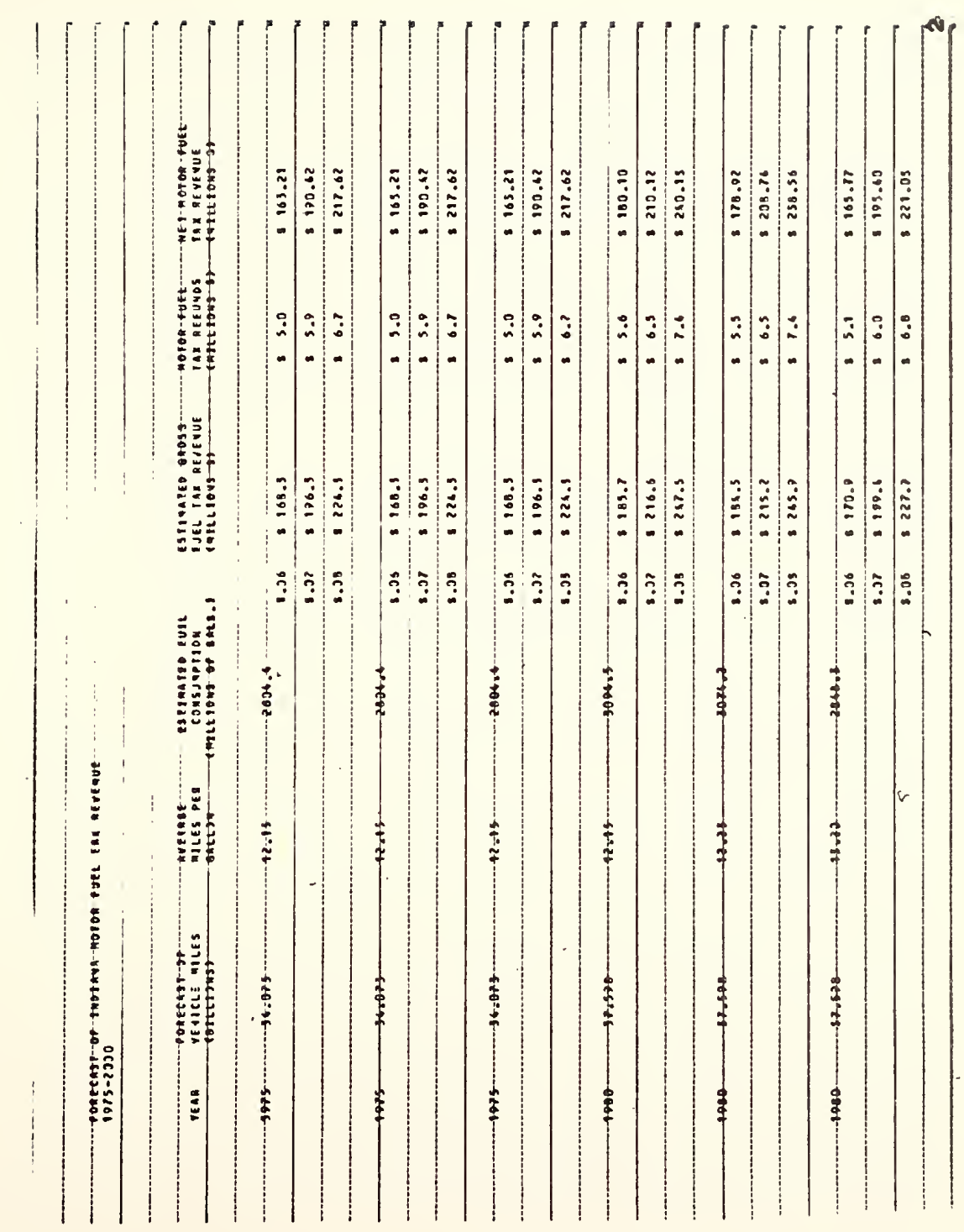




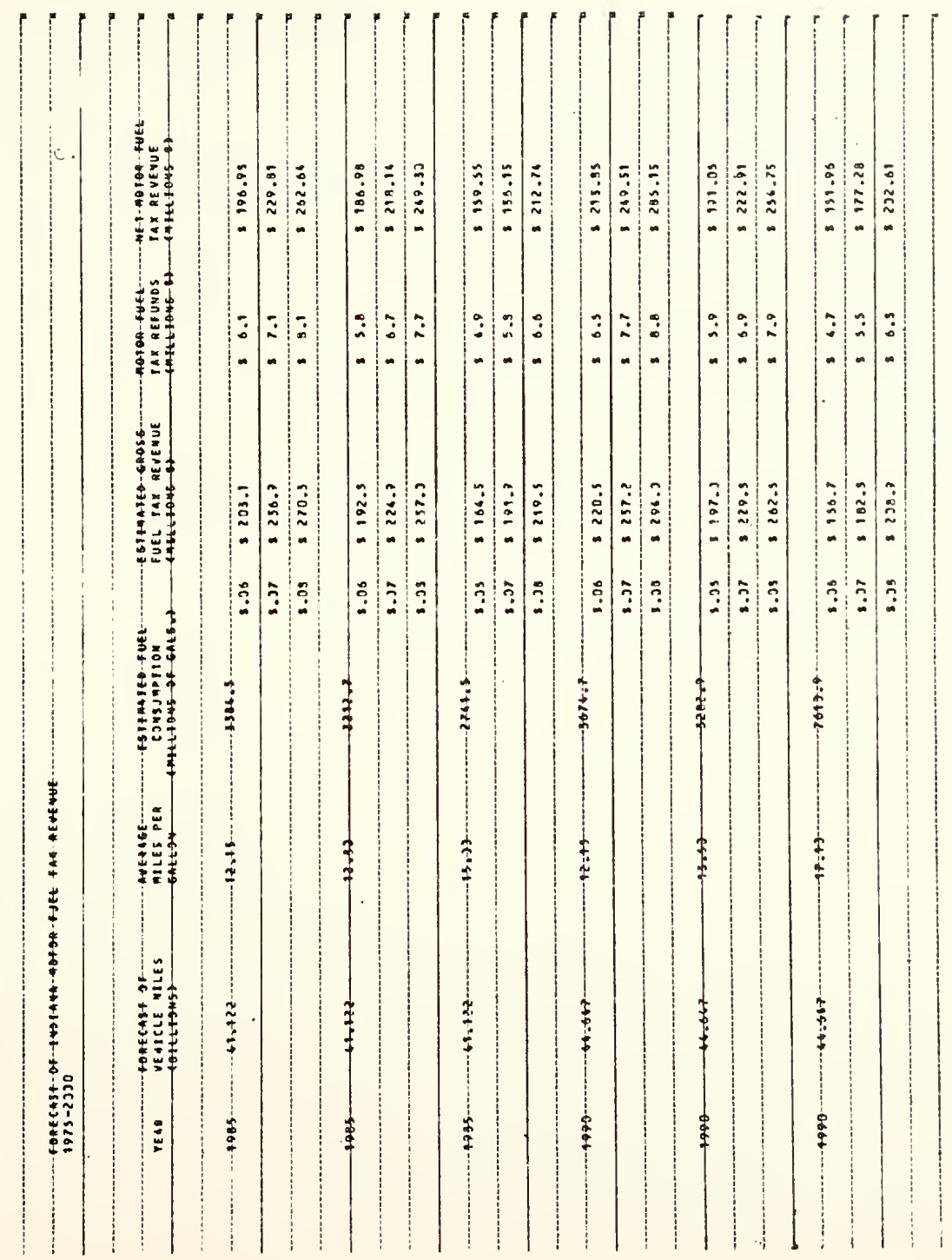


嵌

$\because$ -

$\therefore \div 9$

$\approx \approx \ldots$

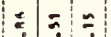

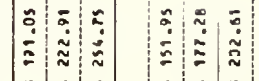

这章

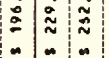

$\begin{array}{ll:l}\infty & \infty & 0 \\ \infty & \infty & \infty \\ \infty\end{array}$

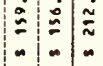

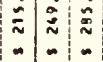

$-1 \infty \infty^{\infty},\left.\infty\right|^{\infty}$

萧

这

\begin{tabular}{lll|}
- & - & $\because$ \\
$\infty$ & 0
\end{tabular}

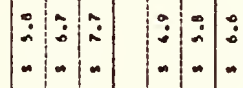

$\begin{array}{ll:l}0 & \vdots & 0 \\ 0 & 0 & 0\end{array}$

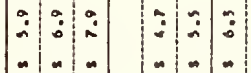

\$ั

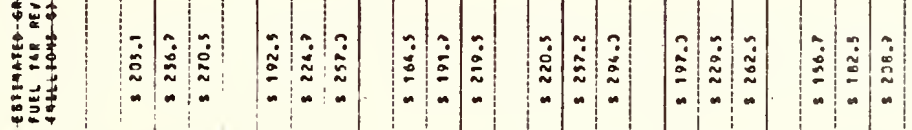

苛高

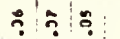

กิรัตุ

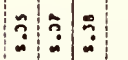

:̊ำ

敦

$\vdots$

$\frac{1}{2}$

$\vdots$

品要

$\pm$

$\stackrel{1}{+}$

i

$\$$

$\pm$

事

$\frac{2}{2}$

$\frac{1}{2}$

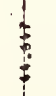

\$

$\$$

के

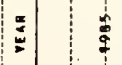

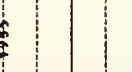

+
$+\infty$
$+\infty$

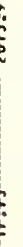

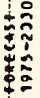

$\frac{7}{5}$

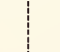




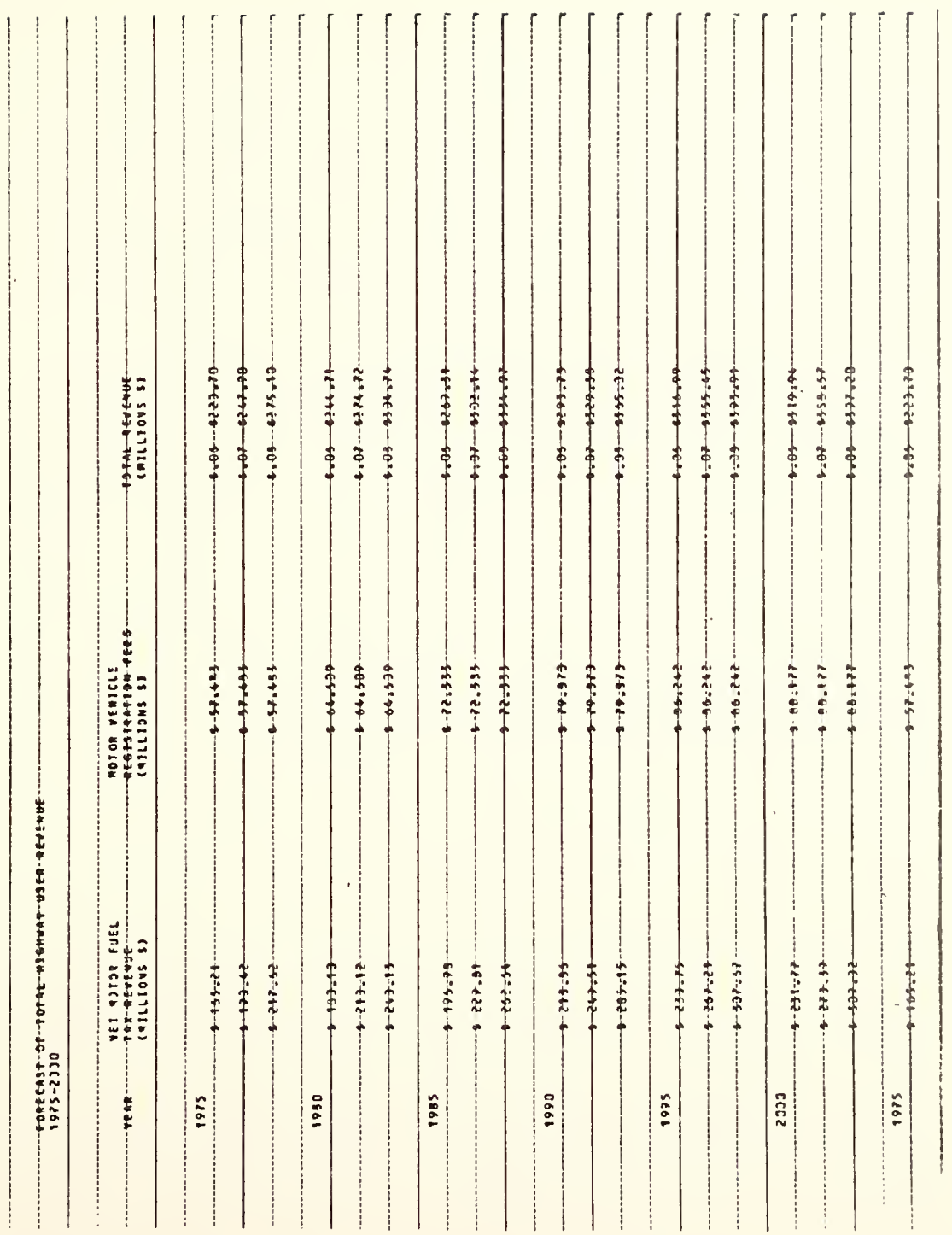




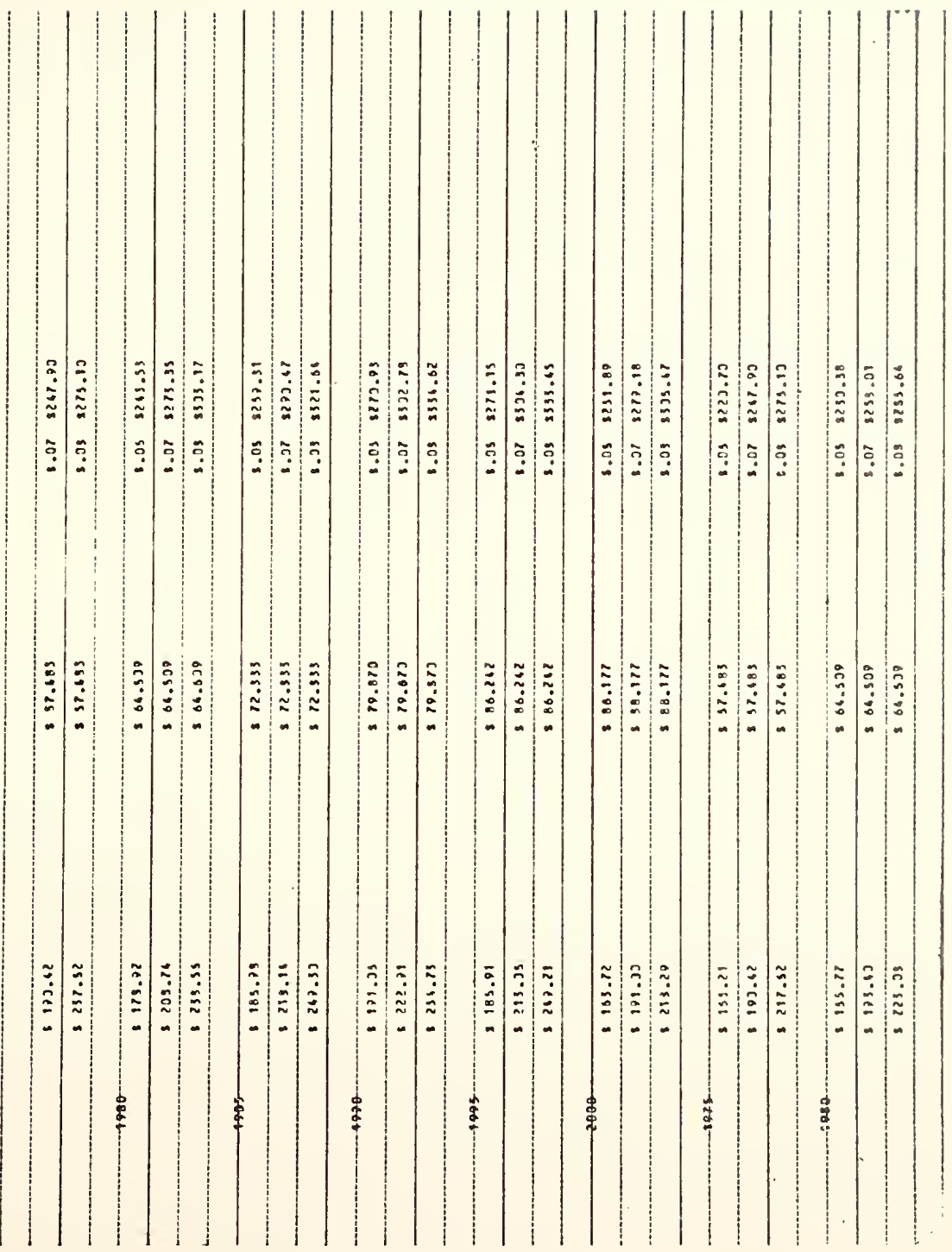




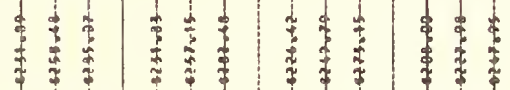

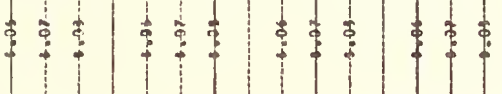

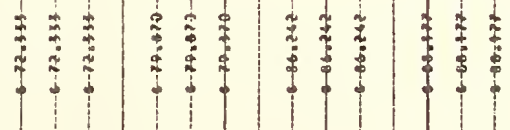

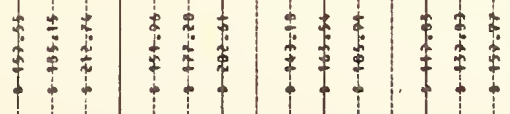

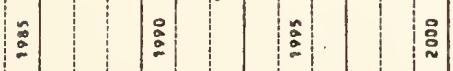



